NBER WORKING PAPER SERIES

\title{
LIQUIDITY TRANSFORMATION AND FRAGILITY IN THE US BANKING SECTOR
}

\author{
Qi Chen \\ Itay Goldstein \\ Zeqiong Huang \\ Rahul Vashishtha \\ Working Paper 27815 \\ http://www.nber.org/papers/w27815 \\ NATIONAL BUREAU OF ECONOMIC RESEARCH \\ 1050 Massachusetts Avenue \\ Cambridge, MA 02138 \\ September 2020, Revised November 2022
}

We benefited from comments by workshop participants at Boston College, Chinese University of Hong Kong, Columbia Burton Conference, Dartmouth Summer Conference, Federal Reserve Board, Shanghai University of Finance and Economics, the 2nd Sun Yat-Sen University, Geneva Finance Research Institute Finance International Conference, Villanova University, University of Utah, Wuhan University, and Yale Accounting Summer Conference. Itay Goldstein has been retained by a law firm as an expert on a case involving a liquidity crisis and government intervention in a European bank. This case has not influenced the research in this paper, and the research in this paper has not influenced the case. The views expressed herein are those of the authors and do not necessarily reflect the views of the National Bureau of Economic Research.

NBER working papers are circulated for discussion and comment purposes. They have not been peer-reviewed or been subject to the review by the NBER Board of Directors that accompanies official NBER publications.

(C) 2020 by Qi Chen, Itay Goldstein, Zeqiong Huang, and Rahul Vashishtha. All rights reserved. Short sections of text, not to exceed two paragraphs, may be quoted without explicit permission provided that full credit, including $(\odot$ notice, is given to the source. 
Liquidity Transformation and Fragility in the US Banking Sector

Qi Chen, Itay Goldstein, Zeqiong Huang, and Rahul Vashishtha

NBER Working Paper No. 27815

September 2020, Revised November 2022

JEL No. E02,G01,G21

\section{ABSTRACT}

One of the key roles of banks is liquidity transformation, which is also thought to create fragility, as uninsured depositors face an incentive to withdraw money before others (a so-called panic run). Despite large amount of theoretical work, there has not been much empirical evidence establishing this mechanism. In this paper, we provide the first large-scale evidence on this mechanism. Banks that perform more liquidity transformation exhibit higher fragility, manifested by stronger sensitivity of uninsured deposit flows to bank performance and greater levels of uninsured deposit outflows when performance is poor. We also explore the effects of deposit insurance and systemic risk.

Qi Chen

Duke University

qc2@duke.edu

Itay Goldstein

The Wharton School

University of Pennsylvania

3620 Locust Walk

Philadelphia, PA 19104

and NBER

itayg@wharton.upenn.edu
Zeqiong Huang

Yale University

165 Whitney Avenue

New Haven, ct 06511

zeqiong.huang@yale.edu

Rahul Vashishtha

Duke University

100 Fuqua Drive

Durham, NC 27708

rahul.vashishtha@duke.edu 


\section{Introduction}

One of the key functions of banks is liquidity transformation. Banks hold illiquid assets, such as loans and illiquid securities, and finance themselves with highly liquid liabilities, such as demand deposits and other forms of short-term debt. This liquidity transformation is thought to play a critical role in the economy, allowing the financing of long-term illiquid investments, while satisfying the demand for liquid money-like assets by investors. At the same time, such liquidity transformation can make banks inherently fragile: they do not hold sufficient liquid assets at all times to meet the immediate withdrawal demands by all depositors. This fragility can lead to runs, whereby depositors rush to withdraw their money from the bank only because they fear others will do the same and the bank will run out of resources. Such fears can then become self-fulfilling outcomes, so called panic-based runs. ${ }^{1}$

A large body of economic theory, going back to Diamond and Dybvig (1983), has been developed to understand banks' role in liquidity transformation and their resulting exposure to panic-based runs. This line of thinking also lies behind government policies that have been shaping the banking industry over the years, trying to mitigate panics, such as deposit insurance and lender of last resort (these ideas go back to Bagehot, 1873). Yet, despite the long lasting impact of these ideas, empirical evidence that clearly links depositors' behavior to liquidity mismatch-driven panic is hard to find in the literature. The goal of this paper is to provide such empirical evidence. We do so using a large sample of U.S. commercial banks over the period 1993-2016.

Traditional bank-run models feature multiple equilibria, where bank runs can either occur or not occur, and so they are difficult to test in the data, as argued by Gorton (1988). Hence, our empirical analysis is guided by more recent theories, which preserve the panic-based feature but provide more precise predictions about when runs are going to occur (see Goldstein and Pauzner, 2005; Chen, Goldstein, and Jiang, 2010; Vives, 2014). Specifically, just like in Diamond and Dybvig (1983), in these theories, banks' liquidity mismatch creates strategic complementarities in depositors' payoffs which increase depositors' incentive to withdraw when they expect that other depositors will withdraw. In addition, depositors receive slightly noisy signals about the fundamentals of the bank and act according to them. These signals inform them directly about the

\footnotetext{
${ }^{1}$ Since the word "panic" may mean different things to different people, we note that its meaning here reflects the way it has been used in the bank-run literature, which often distinguishes between "panic-based" runs and "fundamentalsbased” runs (e.g., Goldstein, 2013). Hence, panic does not reflect anything irrational, but rather it is group behavior resulting from coordination failures leading to an inferior outcome that is not fully justified by fundamentals.
} 
fundamentals but also indirectly about what other depositors know and what they might do. The key equilibrium result of such models is that depositors will run when their signal is below a threshold and will not run when above. Moreover, the threshold increases in the degree of liquidity transformation provided by the bank. In this way, fundamentals and panic jointly determine the fragility of the bank: depositors run when fundamentals are lower, but their proneness to run depends on the degree of liquidity transformation which brings in the element of panic.

We start our analyses with a basic diagnostic of the relation between uninsured deposit flows and bank performance (measured by the return on assets, $R O A$ ) without making any functional form assumptions by using semi-parametric estimation. We find that banks start losing uninsured deposits in response to performance declines only when $R O A$ realizations are sufficiently poor - this region seems to lie well below median ROA. In the above-median region, this flow-performance relation is flat. This relation is consistent with the Goldstein and Pauzner (2005) model, where runs are triggered below a threshold of the fundamentals. The fact that the sensitive region lies well below the median is an indication that banks are mostly stable and the likelihood of fragility and runs is low, which is what we would expect from a well-functioning banking system.

We then turn to our main objective to examine whether the uninsured depositors' withdrawal behavior in poor-performance regions reflects an element of panic. Building on the key insight from the theory that the performance threshold for runs increases with the degree of liquidity transformation, we get two testable predictions that form the core of our empirical analyses. First, the average sensitivity of uninsured depositors' flows to news about bank performance will be stronger for banks that do more liquidity transformation. Intuitively, because of the higher run-threshold, a given bad performance shock is more likely to breach the runthreshold (and trigger panic-based withdrawals) of banks doing more liquidity transformation; this, in expectation, makes uninsured deposit flows of these banks more sensitive to performance. Second, conditional on a given level of poor performance, we also expect high liquidity transformation banks to have lower levels of uninsured deposit flows because of their greater chance of having already experienced panic-based withdrawals. We develop these predictions in detail in Section 2 based on the existing theories.

We emphasize that the way the degree of liquidity transformation affects uninsured deposit flows and their interaction with performance provides support to the panic-based run channel. If 
withdrawals were purely based on fundamentals with no element of panic (as in theories of fundamental-based runs, e.g., Chari and Jagannathan, 1988; Jacklin and Bhattacharya, 1988; Allen and Gale, 1998), there would be no difference in the flow patterns between banks that perform more liquidity transformation and banks that perform less liquidity transformation (we address a key concern below). The degree of liquidity transformation affects uninsured depositors because it makes them more worried about what other uninsured depositors will do.

Implementing this empirical analysis requires us to have measures of liquidity transformation. Liquidity transformation can come from the asset-side, when banks hold more illiquid assets, and from the liability-side, when banks have higher amounts of uninsured deposits. We use the two measures separately to highlight the effect of the different dimensions of liquidity transformation and also interact them in later analysis. For asset-side illiquidity, we rely on the measure developed by Berger and Bouwman (2009). We provide a detailed description of this measure in Section 3. ${ }^{2}$ For the liability side, we simply use the reliance on uninsured deposits, which captures the extent to which banks create liquidity on the liability side without the help of the government-backed deposit insurance. ${ }^{3}$ We refer to these measures as Asset Illiquidity and \%Uninsured. Our main results confirm the above predictions. For both measures of liquidity transformation - Asset Illiquidity and \%Uninsured - banks that create more liquidity exhibit a stronger sensitivity of uninsured deposit flows to performance: a one-standard deviation increase in Asset Illiquidity (\%Uninsured) is associated with more than 33\% (45\%) higher sensitivity of uninsured deposit flows to performance. Moreover, for both measures, conditional on belowmedian performance, banks that create more liquidity have a higher amount of uninsured deposit outflows: a one-standard deviation increase in Asset Illiquidity (\%Uninsured) is associated with about 35\% (35\%) more outflows of uninsured deposit when bank performance declines from above to below median.

A key concern is that the information content of $R O A$ may vary with our measures of liquidity mismatch. Perhaps a decline in ROA (particularly from above- to below-median region) implies a larger reduction in the cash-generating potential of assets of banks with greater liquidity

\footnotetext{
${ }^{2}$ An alternative measure of liquidity transformation is available from Bai et al. (2018). Unlike our measure, the Bai et al. measure incorporates changes in the liquidity of assets and liabilities based on changes in market conditions. As we discuss in detail in Section 3, this makes the Bai et al. measure unsuitable for our purpose because the deterioration in the liquidity of markets for bank' assets itself can be a result of panic.

${ }^{3}$ We explain in Section 3 why the Berger and Bouwman (2009) liability-side liquidity measure is not suitable for our purposes.
} 
transformation. Thus, the stronger adverse reaction of uninsured depositors at these banks may reflect the effect of more fundamental news instead of the effect of panic.

We first note that this concern is mainly applicable to the analyses based on Asset Illiquidity. Banks with different asset illiquidity invest in different asset classes; these asset classes may differ in the statistical/informational properties of the profits they generate. The concern is less applicable to the analyses based on \%Uninsured since it is not directly connected to the cash generating potential of banks' different asset classes. That said, the concern for \%Uninsured may arise indirectly if banks systematically adjust asset side liquidity based on the fragility of their liability side. However, we show that our results for \%Uninsured remain fully intact in a matched sample analysis in which we explicitly eliminate any observable differences in asset composition across banks with different \%Uninsured. We believe this analysis yields some of the cleanest evidence on the effect of strategic complementarities.

We also provide several analyses that mitigate this concern for Asset Illiquidity. First, we explore variation in the effect of Asset Illiquidity based on availability of capital from local peer banks. Granja, Seru, and Matvos (2017) show that assets of distressed banks are mostly sold to local peers and these asset sales happen at a greater fire sale discount when local peer banks have less capital to buy those assets. We therefore expect uninsured depositors to be even more concerned about the illiquidity of their banks' assets when local peer banks have less capital. We show that the effects of assets illiquidity are indeed much stronger when local peer banks have lower capital. This is consistent with the panic channel and, at the same time, there is no clear economic rationale for why informativeness of a bank's ROA would depend upon the capital ratio chosen by peer banks. Second, following a similar logic, we show that the effect of Asset Illiquidity is stronger when the bank is financed with a higher fraction of uninsured deposits. This is precisely what one would expect under the panic channel as an uninsured depositor would care a lot more about the illiquidity of the bank's assets when she/he is surrounded by many other uninsured depositors. This finding is again difficult to explain based on informativeness of $R O A$ as it is not clear why, holding the level of asset illiquidity constant, the information content of $R O A$ would vary with the degree of uninsured deposit financing. Third, we explicitly measure and control for informational properties of $R O A$ and find that our inferences remain virtually unchanged.

In our next set of analyses, we explore the role of deposit insurance - a policy tool that was introduced in 1934 to mitigate panics. Several theoretical studies analyze this role of deposit 
insurance. ${ }^{4}$ We find that the results for insured deposit flows tend to go in the opposite direction to those for uninsured deposit flows when it comes to the effect of liquidity transformation. This suggests that banks actively utilize deposit insurance to manage volatility in uninsured deposits caused by liquidity mismatch. This is consistent with recent evidence by Martin, Puri, and Ufier (2018) and Chen, Goldstein, Huang, and Vashishtha (2022) on how banks deal with the loss of uninsured depositors in times of poor performance by actively attracting insured deposits.

Can high liquidity transformation banks fully offset the loss of uninsured deposits by attracting insured deposits? The answer in general is no. We find that the substitution with insured deposits is only partial when using Asset Illiquidity measure. The evidence is even stronger in the context of the 2008 financial crisis where using both Asset Illiquidity and \%Uninsured we find that high liquidity transformation banks are not fully able to offset the loss of uninsured deposits with insured deposits. It is also important to note that even when substitution with insured deposits is effective, it does not imply that panic stemming from liquidity transformation is costless - the banks end up paying higher deposit rates (as we show later) and insurance premium. The substitution merely changes the nature of costs. Overall, our results indicate that deposit insurance plays an interesting role, but does not make the panic-based fragility irrelevant as one would hope.

Finally, we analyze the differences between idiosyncratic shocks and systematic shocks and how they interact with the panic-based channel. This is important for two reasons. First, the worry of policymakers, heightened by the events of the 2008 financial crisis, is mostly about systematic fragility. Hence, it is important to explore our channel when banks experience systematic shocks. Second, contrasting the results for the two types of shocks provides another test of the strategic complementarities channel. Strategic complementarities are expected to be stronger following a systematic shock because a bank will have greater difficulty in meeting spikes in deposit withdrawals by accessing liquidity from other (also distressed) banks either by selling assets or through interbank borrowings (see models by Shleifer and Vishny, 1992; Liu, 2016; and Goldstein, Kopytov, Shen, and Xiang, 2022). Decomposing banks' ROA into a systematic component and an idiosyncratic component, and interacting with liquidity mismatch, we show that the effects of liquidity mismatch are stronger when the shock is systematic than when it is idiosyncratic, both in terms of higher sensitivity to performance and in terms of lower levels of

\footnotetext{
${ }^{4}$ See Diamond and Dybvig (1983), Rochet and Vives (2004), Keister (2016), Allen, Carletti, Goldstein, and Leonello (2018), and Davila and Goldstein (2022), among others.
} 
uninsured outflows conditional on low performance. Moreover, we use the financial crisis of 2008 as a laboratory to observe the performance and response of banks with different levels of liquidity mismatch during an unexpected crisis episode. We find that during the crisis, banks with greater liquidity mismatch exhibit a greater erosion in their deposit base despite offering higher rates, leading to a lower growth in credit. All these results provide additional evidence for the panicbased channel and call for more thinking among policymakers on how to control it.

Our paper is related to prior empirical work on bank runs. Many early studies establish a strong negative association between bank performance and subsequent banking crises to argue that bank runs seem to be driven by fundamentals and not by panic (e.g., Gorton, 1988; DemirgucKunt and Detragiache, 1998, 2002; Schumacher, 2000). ${ }^{5}$ However, as argued by Goldstein (2013), this interpretation is problematic, since panic itself manifests as a multiplier effect by amplifying depositors' response to bad news about bank fundamentals when strategic complementarities are strong. In this paper, we use exactly this insight to identify the effect of panic on bank deposit withdrawals.

This type of analysis was first introduced to the literature for equity mutual funds in Chen, Goldstein, and Jiang (2010). Similar analysis has been followed later in the context of moneymarket mutual funds in Schmidt, Timmerman, and Wermers (2016), corporate-bond mutual funds in Goldstein, Jiang, and Ng (2017), and life insurance industry in Foley-Fisher, Narajabad, and Verani (2020). We are the first to conduct such analysis for banks, which is arguably where fragility has been most prominent over the years, and where it affected government policies most strongly. The fact that fragility is still present in the banking sector despite the presence of deposit insurance is also an important insight, which could not be obtained in any of the other settings.

There are several recent papers attempting to evaluate the forces behind bank runs empirically. Among them, Iyer and Puri (2012), Iyer et al. (2016), Egan et al. (2017), and Artavanis et al. (2019) are perhaps the most related. Iyer and Puri (2012) and Iyer et al. (2016) explore depositor responses in a case study of one bank run in India that arguably was triggered by panic. Similarly, taking advantage of a special sequence of events in Greece, Artavanis et al. (2019) document presence of panic in depositor behavior using micro-account level data at daily frequency from one large bank in Greece. Egan et al. (2017) study a sample of the 16 largest US

\footnotetext{
${ }^{5}$ Chen et al. (2022) recently analyze the way that such fundamental-based flows are affected by the transparency of the bank about its performance. They do not examine how liquidity transformation affects bank fragility.
} 
retail banks and find that uninsured deposit elasticity to bank distress is sufficiently high to make banks fragile. While evidence of panic-based runs in specific episodes is extremely helpful for understanding bank fragility, it has always been a challenge to document broader evidence of the underlying mechanisms in large samples. Our study attempts to provide such evidence, building on the premise from the theory of bank runs that panic-based runs originate from liquidity mismatch and utilizing the heterogeneity across banks and over time in the degree of liquidity mismatch. The extant empirical literature has not built on this important link between liquidity mismatch and fragility and our paper fills this void.

\section{Theoretical underpinnings}

Since the seminal work by Diamond and Dybvig (1983), several studies use global games techniques to show that the likelihood of panic-based runs increases in the degree of liquidity mismatch (e.g., Morris and Shin, 2000; Goldstein and Pauzner, 2005; Chen et al. 2010; Vives, 2014). In this section, we use the set-up in Goldstein and Pauzner (2005; henceforth, GP) to lay out the theoretical underpinnings of our empirical tests to detect panic-based withdrawals.

GP consider a bank that issues deposit claims to a continuum of consumers at $t=0$ backed by illiquid assets. The assets are illiquid in that their liquidation value at $t=1$ is much lower than the return they generate if held till $t=2$. Fraction $\lambda$ of the consumers experience a liquidity shock (impatient consumers) and need to consumer early at $t=1$ while fraction $1-\lambda$ can wait to consume later at $t=2$ (patient consumers). The degree of liquidity mismatch of a bank is captured by parameter $r_{1}$ which represents the amount that consumers are allowed to withdraw early at $t=1$ : all else equal, a larger $r_{1}$ implies a bank is funding a larger portion of its (illiquid) assets through immediately demandable deposit claims. ${ }^{6}$ Consumers make withdrawal decisions at $t=1$ after observing a noisy, private signal about bank performance (i.e., asset payoffs) $P(\theta)$, which depends on the random state of the economy $\theta \cdot P(\theta)$ increases monotonically with $\theta$ : that is, assets are expected to generate more payoffs as the state of the economy improves. Because

\footnotetext{
${ }^{6}$ Holding the amount of promised demandable claims (i.e., $r_{1}$ ) constant, liquidity mismatch could also be increased by increasing the illiquidity of assets. Chen, Goldstein, and Jiang (2010) and Vives (2014) model this aspect of liquidity mismatch and show that run threshold increases in the degree of asset illiquidity. Similar to these studies, asset illiquidity can be easily accommodated in Goldstein and Pauzner (2005), for example, by assuming that the liquidation value of assets decreases with a parameter $\gamma$ such that for every $r_{1}$ dollar of payment to early withdrawers, the bank needs to liquidate $(1+\gamma) r_{1}$ dollar assets. It follows from Theorem 2 of GP that the run threshold increases in $\gamma$. In our empirical tests, we explore variation in liquidity mismatch resulting from both asset illiquidity and the degree of reliance on uninsured demandable claims.
} 
$P(\theta)$ is a monotonically increasing function of $\theta$, going forward we suppress $\theta$ and discuss all results by referencing to performance $P$ which more directly corresponds to our empirical measure of bank performance (i.e., $R O A$ ).

As expected, impatient depositors always withdraw at $t=1$, contributing to a deposit flow of $-\lambda$. Of more relevance to us, GP show that there is unique performance threshold $P^{*}$ below which patient depositors also withdraw even if the bank is financially solvent - that is, there is a panic-based run. ${ }^{7}$ Because both patient and impatient depositors withdraw, the deposit flow in the below- $P^{*}$ region is -1 . Figure 1, Panel A illustrates various regions of depositor behavior by showing the equilibrium relation between performance realizations and deposit flows.

The central prediction of GP we wish to test is that the performance threshold $\left(P^{*}\right)$ below which panic-based withdrawals occur increases in the degree of a bank's liquidity mismatch, that is, $\frac{\partial P^{*}}{\partial r_{1}}>0$. This comparative static implies that banks with higher liquidity mismatch are more fragile because it takes a smaller deterioration in performance to trigger panic-based withdrawals. In taking the result $\frac{\partial P^{*}}{\partial r_{1}}>0$ to the data we need to deal with the fact that the threshold $P^{*}$ is not observable to us. Hence, what we do is to test the implications of the comparative static $\frac{\partial P^{*}}{\partial r_{1}}>0$ for how the liquidity mismatch $r_{1}$ affects the relation between withdrawal decisions ( flow) and performance realizations $(P)$, both of which we have proxy for. Our tests focus on two aspects of the flow-performance relation that are expected to vary with liquidity mismatch: (i) flowperformance sensitivity and (ii) level of flows.

Below we lay out the rationale for these two tests in two steps. We first highlight two descriptive facts regarding the distribution of performance and the flow-performance relation. As we will explain, these facts are relevant for the intuition underlying the sensitivity prediction and are needed to confirm the intuitive idea that panic-based withdrawals are likely to occur only in regions of sufficiently poor performance. In a well-functioning banking system, one would expect the likelihood of runs to be low and expect banks to be operating in the non-run region most times. We then build on insights from the theory to provide a rigorous rationale for the testable predictions.

\footnotetext{
${ }^{7}$ We follow the global-games literature and consider the limit case where the noise in depositors' private signal is very small (i.e., $\varepsilon \rightarrow 0$ ). The limiting case leads to sharp run thresholds wherein all impatient depositors run just below the threshold. For larger noise, the transition from run to no-run will not be so abrupt, but it does not change our predictions (proof available upon request).
} 
The first empirical fact can be gleaned from Figure 3, Panel A, which presents the semiparametric plots of the relation between deposit flows and ROA. The figure shows that banks start losing uninsured deposits in response to performance declines only when ROA realizations are sufficiently poor - this region seems to lie below median ROA. In the above-median region, this flow-performance relation is flat. Connecting this observation to the threshold in GP, we conclude that the panic-run thresholds $P^{*}$ are located below median performance. Of course, different banks will have their thresholds at different levels, but they seem to be below median performance for at least the vast majority, if not all, of them.

This empirical fact - that withdrawals happen well below median performance - is not surprising. If the run threshold $P^{*}$ was located above the sample median, it would mean that banks would be under runs from their depositors more often than not. This would go against the basic rationale offered for the existence of banks: their ability to produce generally stable money-like claims that facilitate risk sharing among consumers. It seems implausible that a banking system in equilibrium would be so often under stress and still provide liquidity and facilitate risk sharing. As in the GP model, banks can adjust the terms of the demand deposit contract to control the likelihood of runs. This is also reinforced by many government rules and regulations that are meant to keep banks reasonably safe most of the time.

The second empirical fact is available in Figure 2 which shows that the distribution of $R O A$ is approximately symmetric and unimodal around the median. This distribution implies that the probability density function for performance $(f(P))$ is increasing, i.e., $f^{\prime}(P)>0$ in the belowmedian performance region. Since this is the region where the run thresholds $P^{*}$ are located, it follows that banks with a higher run threshold are more likely to experience performance realizations in the region around their $P^{*}$ where flows become sensitive to performance due to panic-based withdrawals. As we formally show next, this intuition underlies the sensitivity prediction.

\subsection{Sensitivity prediction}

Our first test examines whether the average flow-performance sensitivity of uninsured depositors is higher for banks with more liquidity mismatch. This implication of panic-run models has been tested by prior studies in the context of mutual funds (e.g., Chen et al, 2010; Goldstein et al., 2017). The intuition for how this prediction follows from $\frac{\partial P^{*}}{\partial r_{1}}>0$ can be gleaned from Figure 1, Panel A. The flows exhibit sensitivity to performance only if the performance realization is bad 
enough to breach the run threshold: the flows decrease from $-\lambda$ to -1 as $P$ decreases from just above to be just below $P^{*}$. In normal times (i.e., when $P>P^{*}$ ), flows are not sensitive to performance and remain at $-\lambda$. Because the run threshold for a bank with higher liquidity mismatch is greater, it is more likely to be breached, which makes the bank's flows, in expectation, more sensitive to performance.

To see this more formally, consider a continuum of banks of unit mass with liquidity mismatch $r_{1}$ and a run threshold of $P^{*}\left(r_{1}\right)$. These banks face a performance distribution characterized by pdf of $f(P)$ and $\mathrm{CDF}$ of $F(P)$. Consider a small negative perturbation of performance $-\Delta P<0$ to this group of banks. Only banks with performance between $P^{*}\left(r_{1}\right)+$ $\Delta P$ to $P^{*}\left(r_{1}\right)$ will experience a change in flows from $-\lambda$ to -1 , because the perturbation will result in crossing the run threshold for these banks. The rest of the banks will experience no change in flows. Thus, the aggregate change in flows (denoted by $\triangle F L O W$ ) for this group of banks is

$$
\Delta F L O W\left(r_{1}\right)=-\left[F\left(P^{*}\left(r_{1}\right)+\Delta P\right)-F\left(P^{*}\left(r_{1}\right)\right)\right](1-\lambda)
$$

Dividing both sides by $-\Delta P$ and taking $\lim \Delta P \rightarrow 0$ yield the following expression for the average flow-performance sensitivity (AvgFPS) for this group of banks:

$$
\operatorname{AvgFPS}\left(r_{1}\right)=\frac{\partial F L O W\left(r_{1}\right)}{\partial P}=f\left(P^{*}\left(r_{1}\right)\right)(1-\lambda) .
$$

Taking the derivative with respect to $r_{1}$, we obtain:

$$
\frac{\partial \operatorname{AvgFPS}\left(r_{1}\right)}{\partial r_{1}}=(1-\lambda) f^{\prime}\left(P^{*}\right) \frac{\partial P^{*}\left(r_{1}\right)}{\partial r_{1}}
$$

Since $\frac{\partial P^{*}\left(r_{1}\right)}{\partial r_{1}}>0$, it is easy to see that as long as $f^{\prime}\left(P^{*}\right)>0, \frac{\partial \operatorname{AvgFPS}\left(r_{1}\right)}{\partial r_{1}}$ will be positive and the average sensitivity will increase with the degree of liquidity mismatch. The condition $f^{\prime}\left(P^{*}\right)>0$ means that $P^{*}$ is located in the portion of the performance distribution where the density is increasing in $P$. It ensures that as $P^{*}$ increases due to the increase in liquidity mismatch, the breaching of run threshold becomes more likely due to greater density of $P$ in that region. This, in expectation, increases the flow-performance sensitivity as $r_{1}$ increases. As discussed earlier, the condition $f^{\prime}\left(P^{*}\right)>0$ is consistent with the unimodal distribution of performance we observe in data (Figure 2) and the fact that uninsured deposit flows become sensitive to performance only at below-median performance levels (Figure 3, Panel A). 


\subsection{Level Prediction}

The comparative static $\frac{\partial P^{*}}{\partial r_{1}}>0$ also leads to a prediction regarding the levels of deposit flows. Specifically, uninsured deposit flows at higher liquidity mismatch banks should be less than or equal to the flows at low mismatch banks for all levels of performance $P$ :

$$
\text { flow }\left(P, r_{1}^{\text {High }}\right) \leq \text { flow }\left(P, r_{1}^{\text {Low }}\right), \forall P
$$

with strict inequality when performance is in the region of $\left(P^{*}\left(r_{1}^{\text {Low }}\right), P^{*}\left(r_{1}^{H i g h}\right)\right)$. This prediction

can be seen in Figure 1, Panel B: when $P \in\left(P^{*}\left(r_{1}^{\text {Low }}\right), P^{*}\left(r_{1}^{H i g h}\right)\right)$, only banks with high mismatch experience a run and, consequently, lower flows; everywhere else, either both types of banks experience a run or they don't, and in both cases, they have the same level of flows.

The level prediction does not require that the run thresholds $P^{*}$ be located below median performance so that $f^{\prime}\left(P^{*}\right)>0$. That said, since it predicts strict inequality only in the performance region where the run thresholds are located, we expect that the negative relation between liquidity mismatch and the level of uninsured deposit flows to be more salient in the below-median performance region.

The sensitivity and the level tests explore different empirical implications of the central prediction from theory models (that the run threshold increases in the degree of liquidity mismatch). We believe there is value in having both, as the two sets of tests together strengthen the empirical analysis and the interpretation of the results.

\subsection{The role of deposit insurance}

A final issue that deserves clarification pertains to how the availability of deposit insurance affects our predictions. Prior studies show that banks substitute the loss of uninsured deposits with insured deposits in times of poor performance (e.g., Billet et al., 1998; Martin et al., 2018; Chen et al., 2022). If uninsured depositors anticipate that banks will be able to avoid asset liquidations by fully replacing any loss of uninsured deposits by insured deposits, they would lose the incentive to withdraw in anticipation of withdrawals by others, and we would not observe panic-based withdrawals in equilibrium.

We first note that this possibility is likely to reduce the power of our tests in detecting panic-based withdrawals, and the true effect of strategic complementarities (in the absence of deposit insurance) is likely to be larger than what we would find in our sample. We also emphasize 
that we do not expect deposit insurance to fully allay uninsured depositors' concerns about running by other depositors. The issue is that a bank's ability to attract insured deposits is not without constraints and uninsured depositors cannot be certain that their banks will be able to attract sufficient quantity of insured deposits in a timely manner to avoid asset liquidation. ${ }^{8}$ Perhaps unsurprisingly, historically uninsured deposits have not been fully immune to losses even in the era of deposit insurance and have lost money in bank failures (e.g., Benston and Kaufman, 1997). In a later section, we also empirically explore this issue in our sample and find evidence that the substitution between uninsured and insured deposits is not perfect.

\section{Measurement of liquidity mismatch}

Banks undertake liquidity mismatch when they invest in illiquid assets (e.g., loans) using liquid liabilities (e.g., demand deposits). The mismatch exposes even solvent banks to the possibility of panic-based runs, particularly if the deposit financing comes from uninsured depositors who stand to lose money in the event of default. This occurs because the short-term liquidation value of banks' illiquid assets (due to fire sale discount) may not be enough to satisfy a large spike in deposit withdrawals. Thus, an uninsured depositor would like to withdraw (even if she does not need the money for consumption) if she expects a sufficient mass of other depositors to withdraw, creating the possibility of a self-fulfilling panic-run.

We use two measures of liquidity mismatch that capture the two sources of variation in banks' ability to satisfy immediate withdrawal demands from its uninsured depositors: (i) the degree of asset illiquidity (Asset Illiquidity) and (ii) the degree of reliance on uninsured deposit financing (\%Uninsured). All else equal, a bank is more vulnerable to panic-based withdrawals when Asset Illiquidity and/or \%Uninsured are higher.

Our measure of Asset Illiquidity comes from Berger and Bouwman (2009), who create a composite bank-level measure of liquidity transformation by combining measures of asset- and funding-side liquidity. To measure Asset Illiquidity, the authors classify all assets into three categories: (i) illiquid assets (e.g., commercial real-estate loans; commercial and industrial loans), (ii) semi-liquid assets (e.g., consumer loans; residential real-estate loans), and (iii) liquid assets

\footnotetext{
${ }^{8}$ There are many reasons for why banks' ability to attract insured deposits is likely to be constrained. Depositors at competing banks may not be willing to incur the costs of switching from their existing banks or may simply be unaware that other banks are offering higher rates (e.g., Drechsler et al., 2017). Furthermore, competing banks may also respond by offering higher rates to retain their depositor base. Even if sufficient quantity of insured funding is available, it cannot be attracted instantaneously, and uninsured depositors could be concerned that their bank will not be able to attract insured deposits in time to avoid asset liquidation.
} 
(e.g., cash; securities; trading assets). They then assign a weight of $+1 / 2$, 0 , and $-1 / 2$ to each dollar of illiquid, semi-liquid, and liquid assets, respectively. Asset Illiquidity is then calculated as the weighted sum of all assets.

We measure \%Uninsured as the fraction of banks’ total deposits that are uninsured. ${ }^{9}$ With this definition, the measure captures banks' reliance on uninsured- relative to insured-deposit funding. An alternative would be to measure reliance on uninsured deposits relative to all other forms of financing including equity and subordinated debt. The latter choice is problematic for our purpose because the measure would also capture differences in priority of claims on a bank's cash flows: compared to a bank with more equity, an uninsured depositor's claim in a bank with less equity is effectively more junior and it would take a smaller decline in performance to impair that claim. Thus, uninsured depositors at banks with low equity are expected to react strongly to performance declines even in absence of strategic complementarities. ${ }^{10}$

Our measure addresses this problem by allowing us to compare banks with different deposit composition while holding the amount of total deposits, equity, and non-deposit funding sources constant, which we explicitly control for in our empirical specifications. Holding these features of capital structure constant, a dollar of uninsured deposit claim in a bank with high \%Uninsured has the same priority over cash flows as in a bank with low \%Uninsured. ${ }^{11}$ What differs, however, is the degree of strategic complementarities: an uninsured depositor has a larger incentive to withdraw when she knows that most fellow depositors are also uninsured and thus more likely to run.

We also considered an alternative measure of liquidity mismatch (LMI) developed in Bai et al. (2018). Unlike our measures, however, LMI takes into account over time changes in the

\footnotetext{
${ }^{9}$ We use the average value from the previous three years instead of the preceding quarter so that this variable is not simply reflecting any recent trend in the deposit flows. Robustness tests presented in Table A4 of the Online Appendix show that our inferences are qualitatively unchanged if we use \%Uninsured from the preceding quarter.

${ }^{10}$ This is one of the reasons we do not use the measure of funding side liquidity creation from Berger and Bouwman (2009) because their measure considers a bank with less equity as creating more liquidity. Thus, it can also reflect the effect of claim priority as opposed to strategic complementarities because uninsured depositors' claim priority is effectively lower in banks with less equity. Another reason for us not to use this measure is that it doesn't make the distinction between uninsured and insured deposits. This distinction is crucial when it comes to exploring the implications for panic-based runs - a bank may rely a lot on deposit financing without facing much fragility if most of its deposits are insured.

${ }^{11}$ In the event of a bank failure, the FDIC immediately pays off the claims of insured depositors. In exchange for these payments, the FDIC acquires legal claims against the failed bank's assets. The priority of these acquired claims is same as that of uninsured deposit claims. Both FDIC and uninsured depositors pro rata share the proceeds from the liquidation of assets. Thus, a dollar of uninsured deposit claim has the same cash flow rights regardless of the deposit composition. For further institutional details on resolution of bank failures, see, for example, Herzig-Marx (1978).
} 
liquidity of the balance sheet items based on changes in the market conditions. While this makes $L M I$ more accurate in identifying periods of more vs less liquidity stress in the banking system, it makes $L M I$ conceptually problematic for detecting depositor panic using our regressions. This is because deterioration in the liquidity of the markets for banks' assets itself can often be a result of panic among investors including depositors. When panic ensues, there is less capital available to fund asset purchases, resulting in larger fire sale discounts or increased haircuts on collateral assets, which would manifest in deteriorations in LMI. This suggests that panic-based deposit outflows and deteriorations in $L M I$ may be affected by the same factors, ${ }^{12}$ and the former may even precede the latter rather than the other way around. If so, $L M I$ may not significantly predict future deposit flows, even if panic is an important aspect of depositor behavior. Overall, it is not clear if we can use $L M I$ to assess whether it results in depositor panic when it itself might be affected by panic. Our measures do not pose such interpretational difficulties as they do not take market changes in liquidity into account.

\section{Empirical specification and sample}

\subsection{Conceptual underpinnings of the specifications}

Our specifications are guided by a simple model of depositor behavior used in prior studies (e.g., Egan et al., 2017; Chen et al., 2022). Banks attract greater deposit flows when they offer greater utility to depositors (compared to competing banks) and when there is greater aggregate demand for holding deposits. A depositor's utility from a bank depends on her perception of bank's default risk, the deposit rate offered, and service quality. Depositors update their views about default risk as they receive information about bank performance. Thus, deposit growth at a bank can be summarized as a function of the following four factors:

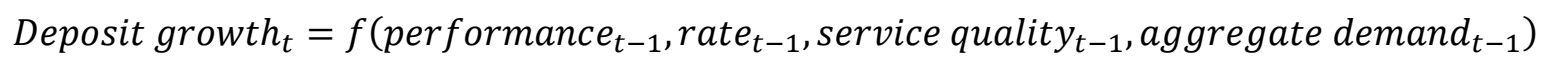

Under the above framework, strategic complementarities affect deposit flows by affecting depositors' beliefs about default risk from bank performance. Because the performance threshold $\left(P^{*}\right)$ for panic-based withdrawals increases in the degree of strategic complementarities, a decline in performance would cause a depositor to worry more about default risk at a bank with higher strategic complementarities due to heightened concerns about withdrawals by other depositors. As we discuss in Section 2, this should manifest in (i) greater deposit flow-performance sensitivity

\footnotetext{
${ }^{12}$ Consistent with this conjecture, Figure A1 in the Online Appendix plots the average uninsured deposit flows and LMIRisk around the 2007-2009 crisis period and shows that uninsured deposits started to decline around the same time when LMIRisk started to deteriorate.
} 
and (ii) lower (or at best equal) level of deposit flows at banks with higher complementarities. These are the two central predictions we take to data using variation in strategic complementarities that results from banks’ degree of liquidity mismatch.

We estimate the above specification using quarterly data from Call Reports. The measure of performance we use is accounting earnings scaled by lagged assets $(R O A)$. Accounting earnings are the key summary performance measure widely used by investors as well as regulators to assess the health of financial institutions. One issue that deserves clarification pertains to the possibility that $R O A$ for period $t-1$ could have been partly shaped (at least for banks with sufficiently poor past performance) by panic-based deposit withdrawals that occurred prior to period $t$-1, instead of purely reflecting fundamentals that are predetermined before depositors' withdrawal decisions. We do not expect this to affect the interpretation of our results. Regardless of how the fundamentals ( $R O A$ ) got determined at time $t-1$, a rational depositor would need to consider what the current level of fundamentals imply regarding banks' future cash flow generating ability and the possibility of withdrawals by other depositors. Theory suggests that, for the same level of fundamentals, regardless of how a bank got there, a depositor's incentive to withdraw would be stronger at a bank with greater liquidity mismatch.

Following Chen et al (2022), we measure deposit flows as the change in deposit balances (scaled lagged assets) over the two quarters following the end of quarter $t-1$ for which bank performance is measured. ${ }^{13}$ This is because banks typically file Call Reports with a delay of 30 days after the calendar quarter ending (Badertscher et al., 2018) and because the literature on postearnings announcement drift suggests that investors respond to quarterly accounting reports with a delay of up to a quarter following the announcement (Bernard and Thomas, 1989).

\footnotetext{
${ }^{13}$ An alternative is to scale deposit flows by the beginning balance of deposits such that uninsured deposit flows measure the percentage change in uninsured deposit base. However, we expect this measure to be less effective at capturing variation in panic-based withdrawals. To see this, consider two banks with high and low reliance on uninsured deposits to fund assets. For the bank with low reliance on uninsured deposits, even a high \%loss in uninsured deposit base may not be too difficult to meet from liquid resources, leading to little threat of asset liquidation. Thus, for this bank even high \%loss in uninsured deposits may not be indicative of panic-based withdrawals. In contrast, for the bank with heavy reliance on uninsured deposits, even a small \%loss in uninsured deposits may be enough to necessitate asset liquidations. Thus, for this bank even small \%loss in uninsured deposit base can be indicative of panic-based withdrawals. Therefore, in the cross section, \%loss in uninsured deposits may exhibit little association with the degree of liquidity mismatch even if liquidity mismatch causes panic-based withdrawals. Scaling by assets addresses this issue by providing a measure that captures the importance of deposit outflows based on the amount of assets they are funding. Nevertheless, we present the robustness of our results to use of lagged uninsured deposit base as scalar in Table A2 of the Online Appendix. Our inferences hold at less than 1\% level in six out of the eight specifications; the results are directionally similar in the remaining two specifications but with weaker statistical significance.
} 
Because panic-based withdrawals can occur quickly (e.g., over a few days) in some cases, a natural question pertains to the nature of runs that can be detected using our quarterly data. ${ }^{14}$ The only types of runs that we cannot capture are the ones that occur and fully reverse before the end of the deposit flow measurement period. Even if the panic-based withdrawals occur quickly, our data would allow us to detect them as long as the lowered deposit levels persist till the end of the measurement period. To the extent the adverse real effects for persistent runs are likely to be more severe, these are the runs that are more important to capture and study.

An advantage of our data is that we can explore the incidence of panic-based withdrawals for a large sample of banks. Such evidence is currently missing in the literature but is quite important to document. Using quarterly data we are able to examine whether there is an element of panic in smaller withdrawals (i.e., those that don't result in extreme outcome of failure and don't get publicized) and how common they are. In addition, our data allow us to link panic-based withdrawals to the degree of liquidity mismatch, which is something that case studies of runs at individual banks cannot do. We later show that for banks that do relatively higher liquidity transformation, just a decline in performance to below median levels is enough to trigger panicbased withdrawals. These smaller but commonplace panic-based withdrawals could be indicative of non-trivial aggregate costs if a wider set of banks are taking subtle yet costly actions, such as curtailing loan growth, avoiding holding illiquid assets, or substituting uninsured with insured deposits, to contain the impact of these withdrawals.

\subsection{Control variables}

Control variables in our specifications serve two broad purposes. First, they help account for the three factors other than bank performance (rate, service quality, and aggregate deposit demand) that can affect deposit growth. Second, they help control for differences in the priority of depositors' claims on cash-flows that can result from differences in funding structure. As discussed in Section 3 earlier, compared to a bank with more equity, an uninsured depositor's claim in a bank with less equity is effectively more junior and it would take a smaller decline in performance to impair that claim. Thus, uninsured depositors at banks with low equity are expected to react strongly to performance declines even in absence of strategic complementarities.

\footnotetext{
${ }^{14}$ Not all runs occur quickly and there have been several episodes of runs characterized by withdrawals over longer periods (Rose, 2015).
} 
Controlling for differences in funding structure allows us to better isolate the effect of strategic complementarities.

To account for time-varying differences in funding structure, we control for (i) capital ratio defined as book value of capital scaled by total assets (Capital Ratio), (ii) wholesale funding scaled by total assets (Wholesale Funding), and (iii) total deposit funding scaled by total assets (\%Deposits). Following prior work (e.g., Acharya and Mora, 2015), we also control for four additional variables that account for differences in size, asset composition, and risk: (iv) the logarithm of asset size ( $\operatorname{Ln}($ Assets), (v) real estate loan share calculated as the amount of loans secured by real estate divided by total loans (RealEstate_Loans), (vi) commercial and industrial loans scaled by total loans (C\&I_Loans), and (vii) the standard deviation of ROE over the preceding 12 quarters.

We include bank fixed effects in most of our analyses. This helps control for unobservables such as time-invariant aspects of service quality. We also expect some of our time varying controls (e.g., size) to mitigate concerns about differences in service quality.

Next, we account for differences in deposit rates. Because Call Reports do not separately report the interest expenses on insured and uninsured deposits, we follow Acharya and Mora (2015) and use the core deposit rate to proxy the rates offered on insured deposits and use the rate on large time deposit to proxy the rates on uninsured deposits. We believe this is a reasonable approximation because core (large time) deposits are most likely to be insured (uninsured). We measure these rates as the quarterly interest expense on the deposits divided by the average quarterly deposits over the same period.

Our final set of controls relates to aggregate demand for deposits. Aggregate demand shocks can occur if, for example, consumers conclude that alternative asset classes (e.g., moneymarket/bond funds or stock markets) will better meet their liquidity/investment needs. Consistent with this, Drechsler, Savov, and Schnabl (2017) and Lin (2020) find that a smaller portion of wealth is allocated to deposits when treasury securities and stock markets offer higher returns. Because our main interest is in examining how deposit withdrawals vary within the banking system as a function of bank specific liquidity mismatch, we do not expect aggregate trends in deposits growth to confound our inferences. Absorbing variation in deposit flows unrelated to default risk, however, can increase the power of our tests. We include both contemporaneous and lagged values of fed funds rates and the value-weighted market returns to control for these opportunity costs of 
holding bank deposits. We include two lags of these variables because we are agnostic about how long it takes for depositors to respond to changes in opportunity cost. ${ }^{15}$

Alternatively, we can use time dummies to fully absorb the effect of aggregate demand shifts. However, this approach would preclude a study of depositor response to changes in bank performance that result from common macroeconomic shocks. This is problematic not only because many significant performance swings in the cyclical banking industry are systematic, but also because we expect the incentive to withdraw before other depositors to be greater when the entire industry is experiencing a performance decline than when the performance decline is idiosyncratic (Liu, 2016; Goldstein et al., 2020). In Section 8.1, we use this differential prediction for response to systematic versus idiosyncratic performance to provide an additional test of the presence of strategic complementarities and find the effect of strategic complementarities to be significantly stronger for systematic performance declines than for idiosyncratic declines. For completeness, we also present our main results after including time dummies where the identification comes primarily from idiosyncratic performance shifts. We find our inferences hold but, as expected, with smaller economic magnitudes.

Following prior work (Egan et al., 2017; Chen et al., 2022), we also contrast the results for uninsured and insured depositors to allay any residual concerns about imperfect controls. The idea is that while insured depositors care less about default risk and bank performance, they still are affected by service quality or other relevant bank attributes that are unrelated to default risk. If our specifications are simply reflecting the effect of these factors instead of panic from concerns about bank default, we should find similar results for uninsured and insured deposits. As we show later, we find the opposite to be the case.

One final issue that deserves discussion relates to the possibility of customer relationships as an omitted correlated variable. Because of greater switching costs, relationship depositors may exhibit stickier flows and thus low flow-performance sensitivity. We cannot explicitly control for such switching costs because data to identify depositor relationships are not publicly available. ${ }^{16}$ We, however, emphasize that this can confound inferences only if banks with high liquidity

\footnotetext{
${ }^{15}$ In untabulated analyses we confirm that our inferences are fully robust if we include only one lag or do not control for these variables at all.

${ }^{16}$ The limited prior evidence on the connection between depositor relationships and fragility comes from case studies of either one or two banks (Iyer and Puri, 2012; Iyer et al., 2016; Martin, Puri, and Ufier, 2018) or from consumer finance survey of a limited number of households in Switzerland (Brown et al., 2020).
} 
mismatch make systematically fewer investments in building depositor relationships. We are not aware of any theoretical or empirical research that suggests this to be the case. If anything, to the extent relationships indeed reduce depositor fragility, we would expect banks with higher liquidity mismatch to invest more in them to counter the fragility from strategic complementarities. ${ }^{17} \mathrm{We}$ also document (in Section 6.2.1) cross-sectional patterns in the effects of liquidity mismatch that are consistent with panic and cannot be explained by customer relationships.

\subsection{Data and sample}

Our sample is at commercial bank-quarter level. We obtain most of our bank-level variables from U.S. Call Reports as disseminated by the Wharton Research Data Services (WRDS). ${ }^{18}$ Call Reports contain quarterly data on all commercial banks' income statements and balance sheets. The Appendix provides all variable definitions and details which specific Call Report items are used to measure these variables. To avoid the impact of mergers and acquisitions, we exclude bank-quarter observations with quarterly asset growth greater than $10 \%$. We also exclude bank quarters with total assets smaller than 100 million and winsorize all continuous variables at $1 \%$ and $99 \%$. These sample-selection and cleaning procedures are commonly used in prior work (e.g., Gatev and Strahan, 2006; Acharya and Mora, 2015). Our final sample spans January 1994 to December 2016 (the last quarter where the Asset Illiquidity variable is available from Christa Bouwman's website) and contains a maximum of 287,018 bank-quarter observations representing 8,153 unique commercial banks.

Descriptive statistics in Table 1 show that the average (median) annualized $R O A$ is $1 \%$ (1.08\%) with a standard deviation of $0.90 \%$. The average annualized growth in uninsured (insured) deposits is $2.12 \%(2.79 \%)$ of assets. The correlation (untabulated) between uninsured deposit flows and lagged $R O A$ is much higher (at 0.14 ) than that between insured deposit flows and $R O A$ (at 0.02), suggesting that uninsured deposit flows are more sensitive to bank performance. Furthermore, uninsured and insured deposit growth exhibit a strong negative correlation of -0.32 , consistent with banks substituting for loss of uninsured deposits by insured deposits.

\footnotetext{
17 There is another reason why, if anything, liquidity mismatch and customer-relationships may be positively correlated. To the extent that relationship-based loans are more likely to be illiquid (due to outsiders' concern about information advantage held by relationship banks), and that relationship with borrowers is positively related to relationship with depositors, we would expect banks with higher Asset Illiquidity to have stronger relationship with depositors.

${ }^{18}$ Since the coverage of Call Reports at WRDS is incomplete after 2014, we supplement the post-2014 data using S\&P’s SNL financial database.
} 


\section{Liquidity mismatch and flow-performance relation}

\subsection{Semi-parametric analyses}

We begin with an exploratory analysis of the relation between deposit flows and bank performance using semi-parametric regressions so that we do not make functional form assumptions. The specification takes the following general form:

$$
\Delta D e p_{i t}=f\left(R O A_{i t-1}\right)+\text { Control }_{i t-1}+\epsilon_{i t}
$$

where $\Delta D e p_{i t}$ represents deposit flows, measured as the change in deposit balance scaled by lagged total assets, $R O A_{i t-1}$ is the bank's return on assets that depositors observe at the end of quarter $t$-1, and Control $_{i t-1}$ represents the set of time-varying control variables explained earlier. Following prior studies (e.g., Chevalier and Ellison, 1997; Chen et al., 2010; Goldstein et al., 2017), we use Robinson’s (1988) estimator implemented using Gaussian local kernel regressions.

We first contrast the flow-performance relation for insured and uninsured depositors. Figure 3, Panel A illustrates the estimated relation for the two types of depositors. Two patterns are noteworthy. First, as expected, in contrast to uninsured depositors, insured deposit flows exhibit a relatively flat relation with $R O A$ over the entire range of performance. Second, while uninsured deposit flows are virtually indistinguishable from insured deposit flows when bank performance is (roughly) above median, they start declining steeply as performance deteriorates to below median levels. As discussed in Section 3, this fact indicates that the panic-run thresholds $\left(P^{*}\right)$ are located below median performance for at least the vast majority of our sample banks. Together with the unimodal distribution of $R O A$ for our sample banks shown in Figure 2, it supports the assumption underlying our sensitivity prediction (i.e., $f^{\prime}\left(P^{*}\right)>0$ ), and highlights the importance of focusing on regions of poorer performance when trying to detect panic-based withdrawals.

Next, to explore the role of strategic complementarities, we divide banks into terciles based on either the level of Asset Illiquidity or \%Uninsured and then estimate the flow-performance relation separately for the bottom and the top terciles. Panels B and C present the plots for the terciles of Asset Illiquidity and \%Uninsured, respectively. Compared to banks with low Asset Illiquidity and \%Uninsured, banks with high Asset Illiquidity and \%Uninsured either have similar (Panel C) or slightly higher levels of (Panel B) uninsured deposit flows in the above-median region of performance. The two groups of banks, however, exhibit dramatically different outcomes in region of poor, below-median performance: banks with higher Asset Illiquidity and \%Uninsured 
exhibit a much sharper decline in uninsured deposits as $R O A$ deteriorates in this region such that these banks eventually end up with much lower uninsured deposit flows. Overall, consistent with bank-run theories, the above evidence suggests that uninsured depositors are significantly more fragile for banks that hold more illiquid assets and obtain a larger fraction of financing from uninsured depositors.

While semi-parametric estimation permits estimation of the flow-performance relation without making functional form assumptions, it is difficult to accommodate bank fixed effects and to conduct formal tests of statistical differences in depositor behavior across banks of different levels of liquidity transformation. We employ parametric regressions in the rest of the paper to address these issues.

\subsection{Parametric regressions}

\subsubsection{Liquidity mismatch and flow-performance sensitivity}

We first examine how the flow-performance sensitivity of uninsured depositors varies with the degree of liquidity mismatch. As discussed in Section 2, if strategic complementarities play a role in shaping uninsured depositors' withdrawals, we expect the average sensitivity to be higher for banks with more liquidity mismatch. We estimate various versions of the following specification:

$\Delta \operatorname{Dep}_{i t}^{u}=\alpha_{i}+\beta_{0} R_{0 A_{i t-1}}+\beta_{1}$ MisMatch $_{i t-1} * R_{0 A} A_{i t-1}+\beta_{2}$ MisMatch $_{i t-1}+$ Control $_{i t-1}+\varepsilon_{i t}$,

where MisMatch represents one of the two measures of liquidity mismatch (Asset Illiquidity or \%Uninsured), $\alpha_{i}$ represents fixed effect for bank $i$, and the control variables are as defined before. We estimate Eqn. (3) using ordinary least squares (OLS) and obtain standard errors after two-way clustering at the bank- and quarter-level. We use the demeaned version of MisMatch (i.e., MisMatch minus sample mean), so that the coefficient $\beta_{0}$ captures the flow-performance sensitivity for a bank with average MisMatch. ${ }^{19}$ In addition to the control variables we discussed earlier, we also include the interaction terms between $R O A$ and the demeaned values of the timevarying bank characteristics to ensure that $\beta_{1}$ is not picking up the effects of banks' funding structure or asset composition unrelated to strategic complementarities.

Table 2, Panel A presents the results with Asset Illiquidity as the mismatch measure. Column (1) presents the estimates without bank fixed effects to exploit both time series and cross-

\footnotetext{
${ }^{19}$ Throughout the paper, we use demeaned value of a variable when it is interacted with $R O A$ so that $\beta_{0}$ continues to represent the sensitivity for the average bank.
} 
sectional variation in our liquidity mismatch measure. The coefficient for $R O A$ is significantly positive at less than $1 \%$ level (coef $=1.158$ ); the coefficient for the interactive term between $R O A$ and Asset Illiquidity is also positive (coef $=2.721$ ) and statistically significant at less than $5 \%$ level. Together, they indicate that the flow-performance sensitivity of uninsured deposits increases with a bank's asset illiquidity. The magnitude is economically meaningful: a one-standard-deviation increase in Asset Illiquidity is associated with a 33\% $(=.14 * 2.721 / 1.158)$ increase in the flowperformance sensitivity.

In column (2), we examine if, like we found in semi-parametric analyses, differences in the sensitivity for banks with different asset illiquidity manifest mainly when banks experience below median performance. We do so by using a linear spline regression that fits a continuous piece-wise linear specification connected at different points (called knots) while allowing a different slope for each linear segment between the knots. For our test, we fit two linear segments connected at the median $R O A$. The estimation involves replacing $R O A$ in the regression with two vectors (ROA1 and $R O A 2$ ) whose coefficients capture the marginal effect of $R O A$ in regions below and above median $R O A .{ }^{20}$ Estimates in column (2) confirm the findings from the semi-parametric plots: the coefficient on the interaction of Asset Illiquidity with below-median levels of ROA (ROA1) is statistically significant at $1 \%$ level (coef $=3.953$ ) but with above-median levels of $R O A$ (ROA2) is insignificant at conventional levels (coef $=0.300$ ).

Next, column (3) presents the estimates from our preferred specification that includes bank fixed effects. Inferences are robust. Both the coefficients on $R O A$ and its interaction with Asset Illiquidity are statistically significant at less than $1 \%$ level, and the economic magnitude of the effect increases slightly: a one-standard-deviation increase in Asset Illiquidity is associated with a $34.5 \%$ increase in the flow-performance sensitivity. In the rest of the paper, when examining the effects on sensitivity, we present estimates from this specification.

Finally, for completeness, column (4) presents the robustness of our results to the inclusion of time dummies instead of macroeconomic-controls (fed-fund rate and stock returns) to absorb the effect of any secular trends in deposit growth. As discussed in Section 4, this is not our preferred specification because it does not allow us to study depositors' response to systematic industry-wide declines in performance, which is when we expect the incentive for panic-based

\footnotetext{
${ }^{20}$ Specifically, $R O A 1_{i t-1}=\operatorname{Min}\left(R O A_{i t-1}, R O A M e d i a n\right)$ and $R O A 2_{i t-1}=\operatorname{Max}\left(R O A_{i t-1}, R O A M e d i a n\right)$. For more details on the estimation procedure, see Greene (1993, pp. 235-238) and Seber and Wild (1989, pp. 481-489).
} 
withdrawal to be greater. Later in Section 8, we explore this differential prediction for response to systematic and idiosyncratic performance to provide an additional test for the effect of strategic complementarities. Estimates in column (4) show that all coefficients of interest are significant at less than $1 \%$ level although with smaller economic magnitude: a one-standard-deviation increase in Asset Illiquidity is now associated with a $25 \%$ increase in flow-performance sensitivity. The smaller magnitude is expected as including time dummies restricts the identification to come primarily from idiosyncratic performance shifts.

Table 2, Panel B presents the results using \%Uninsured as our proxy for liquidity mismatch. All of our inferences are robust and the coefficients on $R O A$ and its interaction term with \%Uninsured are significant at less than $1 \%$ level in all specifications. The economic magnitudes of the effects are also large. For example, estimates from the specification with bank fixed effects (column (3)) imply that a one-standard-deviation increase in \%Uninsured is associated with a nearly $45 \%$ (=15.13*0.041/1.386) increase in the flow-performance sensitivity. ${ }^{21}$

\subsubsection{Liquidity mismatch and level of uninsured deposit flows}

We next present results from testing the second prediction that all else equal, the level of uninsured deposit flows at banks with more liquidity mismatch should be less than or equal to the flows at banks with less liquidity mismatch for all performance levels and with strict inequality in regions where the run thresholds are located. Intuitively, this prediction results from the fact that at any level of performance there is a greater chance that a bank with high liquidity transformation has already experienced panic-based withdrawals due to its higher run-threshold.

To test this prediction, we first sort all observations into deciles of $R O A$ and then examine, within each decile, how the level of uninsured deposit flow varies with the degree of liquidity mismatch. Specifically, we estimate the following regression:

$\Delta D e p_{i t}^{u}=\alpha_{i}+\beta_{0} R O A_{i t-1}+\sum_{d=1}^{10} \beta_{d}$ MisMatch $_{i t-1} \times I_{i t}^{d}+\sum_{d=1}^{10} \gamma_{d} I_{i t}^{d}+$ Control $_{i t-1}+\varepsilon_{i t},(4)$

where $I_{i t}^{d}$ is the indicator variable for whether an observation's level of ROA belongs to decile $d$ of $R O A$. Coefficient $\beta_{d}$ in this specification measures how the level of uninsured deposit flows within decile $d$ of $R O A$ varies with the degree of liquidity mismatch.

\footnotetext{
${ }^{21}$ While not the focus of our analysis, in untabulated results, we do find that consistent with the claim priority effect, the sensitivity of uninsured deposit flows to $R O A$ is higher in banks with lower capital ratio.
} 
Figure 4 visually illustrates the findings by plotting the coefficients $\beta_{d}$ for all deciles. The results are consistent with our prediction and with what we found in the semi-parametric analyses. Panel A presents the results for Asset Illiquidity. The coefficient estimates for the top 5 deciles above median $R O A$ are close to zero and not significantly different from zero. The picture changes dramatically when we look at the coefficient estimates for the bottom 5 deciles: The coefficient estimate becomes negative at -0.06 for decile 5 and decreases monotonically in magnitude to -14.06 for decile 1, with estimates for the bottom two deciles significantly different from zero. The average coefficient estimate for the above-median deciles is 1.437 , compared to the average

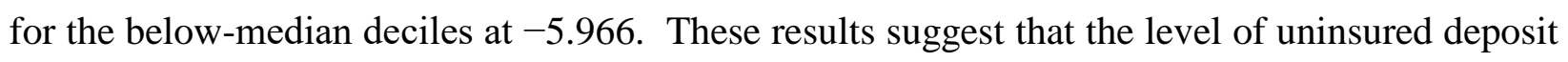
flows does not vary with asset illiquidity in the above-median performance region but as performance deteriorates to below median, banks with greater asset illiquidity experience significantly greater outflows.

Equation (4) is quite demanding on data as it looks for differential effects of asset illiquidity within narrow bands (deciles) of bank performance. Therefore, based on the analysis above, going forward, we use a simpler regression that parsimoniously summarizes the differential effect of Asset Illiquidity on the level of uninsured deposit flows in the two regions of ROA performance. This parsimony not only provides greater statistical power to our tests but will also be useful when we later explore the interactions of Asset Illiquidity with other variables. Specifically, we estimate the following modified version of Eqn. (4) where we replace the ten decile dummies with one indicator for below median performance $\left(I_{R O A<M e d}\right)$ :

$\Delta \operatorname{Dep}_{i t}^{u}=\alpha_{i}+\beta_{0} R_{0 A_{i t-1}}+\beta_{1}$ MisMatch $_{i t-1} * I_{R O A<M e d}+\beta_{2} * I_{R O A<M e d}+$ Control $_{i t-1}+\varepsilon_{i t .}$. (5)

In addition to standard controls, we also include interactions of $I_{R O A<M e d}$ with all time-varying bank characteristics to control for their differential impact across the two regions of bank performance. The key coefficient of interest is on the interaction term Asset Illiquidity * $I_{R O A<M e d}$ which captures the effect of asset illiquidity on uninsured deposit flows as performance deteriorates from above- to below-median.

Table 3 presents the results from estimating Eqn. (5). Column (1) presents the estimates with Asset Illiquidity as the measure of liquidity mismatch. The coefficient on the interactive term Asset Illiquidity $* I_{R O A<M e d}$ is negative (coef $=-5.281$; $p$-value $<0.01$ ), implying that banks with higher asset illiquidity experience additional uninsured deposit outflows as the performance deteriorates from above to below median. In terms of economic magnitude, the additional outflows 
resulting from a one-standard-deviation increase in asset illiquidity are equivalent to 35\% $(=0.14 * 5.281 / 2.11)$ of the mean uninsured deposit flows in our sample.

We obtain even stronger inferences when we use \%Uninsured as the measure of liquidity mismatch. Figure 4, Panel B visually illustrates the effect of \%Uninsured for each decile of ROA. Unlike for asset illiquidity, the coefficients on \%Uninsured are negative and statistically significant even for the five above median deciles, with the average value of coefficient being -0.205. A possible explanation for this result is that compared to banks with low \%Uninsured, concerns about panic-based running are heightened at banks with high \%Uninsured such that they either do not wish to attract, or have trouble attracting, more uninsured deposits even in times of normal/good performance. It is worth noting that technically this explanation is outside of the scope of traditional bank-run models (e.g., Goldstein and Pauzner, 2005) that feature only one bank with an exogenously given composition of depositors. More in line with the traditional run models and consistent with our results for asset illiquidity, we find that the coefficient on \%Uninsured starts declining monotonically as one moves down to the below median deciles (coef for decile $5=-0.232$ and for decile $1=-0.347$ ); the average coefficient for the below median deciles is -0.271 , which is nearly $33 \%$ greater in absolute magnitude than that for the above median deciles.

Column (2) of Table 3 presents the result from parsimonious regressions that summarize the differential effect of \%Uninsured in the two regions of ROA performance. The coefficient on $\%$ Uninsured $\times I_{R O A<M e d}$ is negative (coef $=-0.049$; $p$-value $<0.01$ ), implying that banks with higher \%Uninsured experience additional uninsured deposit outflows as the performance deteriorates from above- to below-median. In terms of economic magnitude, as one moves from above- to below-median ROA, a bank whose \%Uninsured is one-standard-deviation higher experiences additional outflows that are equivalent to $34 \%(=15.13 * 0.049 / 2.11)$ of the mean uninsured deposit flows in our sample.

In Table A1 of the Online Appendix, we also present the results separately for subsamples of small, medium, and large banks. We find that all of our results hold across all subsamples, except that the result on the level specification is insignificant for large banks when we use \%Uninsured as the proxy for mismatch. This could reflect the significantly smaller sample size and/or the effect of "too-big-to-fail” for large banks. 


\section{Could the results reflect differences in information content of $R O A$ ?}

A potential concern is that the information content of $R O A$ may vary with our measures of liquidity mismatch. Perhaps a decline in $R O A$ (particularly from above- to below-median region) implies a larger reduction in the cash generating potential of assets of banks with greater liquidity mismatch. Thus, the stronger adverse reaction of uninsured depositors at these banks may reflect the effect of more fundamental news instead of panic.

We first note that this concern is mainly applicable to the analyses based on Asset Illiquidity. Banks with different asset illiquidity invest in different asset classes; these asset classes may differ in the statistical/informational properties of the profits they generate. The concern is less applicable to the analyses based on \%Uninsured since it is not directly connected to the cash generating potential of banks' different asset classes. That said, the concern for \%Uninsured may arise indirectly if banks systematically adjust asset side liquidity based on the fragility of their liability side. For example, a bank with significant liquid claims on the liability side may create less liquidity on the asset side to manage liquidity mismatch risk.

In this section, we first address this residual concern about \%Uninsured by using a matched sample analysis in which we explicitly eliminate any observable differences in asset composition across banks with different \%Uninsured. We believe this analysis yields some of the cleanest evidence on the effect of strategic complementarities. We then provide a variety of additional analyses that show our inferences from Asset Illiquidity are unlikely to be driven by differences in information content of $R O A$.

\subsection{Matched sample analyses for \%Uninsured}

For this analysis, we start with observations in the top and the bottom terciles of \%Uninsured. We then propensity-score match the observations in the two terciles based on variables that capture banks' asset illiquidity and asset composition (Asset Illiquidity, RealEstate_Loans, and Commercial_Loans) as well as other bank characteristics. ${ }^{22}$ We use nearest neighbor matching without replacement with a caliper of 0.005 and require common support for the propensity scores across the two groups.

\footnotetext{
${ }^{22}$ In sensitivity tests (results untabulated), we find that our inferences are virtually identical when we match based only on the three asset composition variables. The parsimonious matching approach yields a slightly larger sample size of 113,320 compared to 92,748 for the comprehensive matching approach.
} 
Table 4, Panel A presents the covariate balance and shows that the matching is quite successful: the mean values of all variables are extremely close for the top and bottom terciles of \%Uninsured and none of the differences are statistically significant. For example, the mean Asset Illiquidity for the top and bottom terciles is nearly identical at 0.076.

We estimate our prior regression specifications on the matched sample with an indicator variable $\left(I_{\text {High } \% \text { Unin }}\right)$ for membership in the top tercile of \%Uninsured as the measure of MisMatch. Panel B, columns (1) presents the findings regarding the performance sensitivity of uninsured depositors. The coefficient estimates on both $R O A$ and $R O A \times I_{H i g h} \%$ Unin are positive and significant at less than $1 \%$ level. They imply that, compared to banks in the bottom tercile, the average sensitivity of uninsured deposit flows to ROA in banks in the top tercile of \%Uninsured is three times higher (1.654 vs. 0.509). Unsurprisingly, because of the matching, in column (2) when we include Asset Illiquidity and its interaction with ROA to control for any differences in asset illiquidity across the two terciles of \%Uninsured, we find little change in the coefficient estimates for $R O A$ and $R O A \times I_{\text {High } \% \text { Unin }}$.

The findings regarding the effects of \%Uninsured on the levels of uninsured deposit flows are similarly robust. Columns (3)-(4) of Table 4, Panel B present the results from estimating Eqn. (5). The coefficient on $I_{\text {High } \% \text { Unin }} \times I_{R O A<\text { Med }}$ in column (3) is -2.045 ( $p$-value $<0.01$ ), which implies that compared to a bank in the bottom tercile, a deterioration in performance from aboveto below-median for a bank in the top tercile of \%Uninsured results in additional outflows equivalent to $96 \%$ of the sample average level of uninsured flows. Similarly, there is little change in the coefficient estimates when we explicitly control for Asset Illiquidity and its interaction with $I_{\text {High \%Unin }}$ in column (4).

\subsection{Mitigating concerns regarding inferences from Asset Illiquidity}

We provide two types of analyses to mitigate concerns about our inferences from the results on Asset Illiquidity. First, we present evidence on additional patterns in the effects of Asset Illiquidity that are consistent with the effect of strategic complementarities but are unlikely to be correlated with any differences in the informational properties of ROA. Second, we explicitly measure the informational properties and control for them in our regressions.

\subsubsection{Additional patterns in the effects of asset illiquidity}

We explore two sources of variations in the effect of asset illiquidity. First, we explore the variations based on the availability of capital from local peer banks. Granja, Matvos, and Seru 
(2017) find that assets of failed banks are predominantly sold to banks with operations in the same geographic locations as the failed banks, consistent with local peer banks possessing better information to value assets originated in the same area. They further find that the asset sales happen at a greater fire-sale discount when the peer banks have less free capital to buy those assets. We therefore expect uninsured depositors to be even more concerned about the illiquidity of their banks' assets when the peer banks have less free capital: the depositors know that their banks' illiquid assets will command much lower prices in case they need to be liquidated. Under the assumption that the informational properties of earnings generated by a bank's assets do not depend on the capital ratios chosen by its geographic peers, this analysis can mitigate concerns about the confounding effect of the differential information content of ROA.

Following the approach in Granja et al. (2017), we measure local capital availability using the average capital ratio of all peer banks located in the same MSA (PeerCapital). We then estimate regressions that allow the effect of Asset Illiquidity to vary with the top, middle, and bottom terciles of PeerCapital and present the results in Table 5, Panel A.

Columns (1) to (3) show the results for the flow-performance sensitivity specification. The coefficient on Asset Illiquidity $\times R O A$ decreases monotonically as the availability of the peer capital increases from the bottom to the top tercile, and the difference in coefficients between top and the bottom tercile is statistically significant at less than $5 \%$ level. The economic magnitude of the variation is also quite large: the effect of asset illiquidity on the flow-performance sensitivity in the bottom tercile is more than three times the effect in the top tercile (5.535 vs. 1.611).

Columns (4) to (6) show the results for the level analysis, which show a similar monotonic pattern. The magnitude of the coefficient estimate for Asset Illiquidity $\times I_{R O A<M e d}$ increases nearly 2.5 times when we move from the top tercile of peer capital (coef=-2.941) to the bottom tercile (coef=-7.360). Overall, as expected, the results show that effect of asset illiquidity on deposit fragility is much stronger when there is less capital available to buy those assets.

In our second analysis, we explore how the effect of asset illiquidity on deposit fragility varies with the degree of \%Uninsured. We expect the effect of asset illiquidity to become stronger as \%Uninsured increases. Intuitively, when financing mainly comes from insured depositors, there is little incentive to run even if the assets are highly illiquid: an uninsured depositor knows that even if other uninsured depositors withdraw, cash withdrawals will not be large enough to trouble 
even a bank with primarily illiquid assets. The depositor, however, would increasingly get more concerned about the illiquidity of assets as there are more of other uninsured depositors.

Table 5, Panel B presents evidence on how the effect of Asset Illiquidity varies for the three terciles of \%Uninsured. As predicted, the effect of Asset Illiquidity monotonically increases as one moves from the bottom to the top tercile of \%Uninsured for both the sensitivity and level of flows. The magnitude of the effect is large. The effect of asset illiquidity on flow-performance sensitivity in the top tercile of \%Uninsured is nearly 2.5 times the effect in the bottom tercile, although the difference between the two terciles is significant at only $11 \%$ level. When it comes to the effects on the level, however, the differences are both economically large and statistically significant at traditional levels: the coefficient on Asset Illiquidity $\times I_{R O A<M e d}$ for the top tercile is nearly 4 times the coefficient for the bottom tercile, with the difference significant at less than the 5\% level. These results again mitigate concerns about the confounding effect of information content of ROA: it is not clear why, holding the level of asset illiquidity constant, the information content of ROA would vary with the degree of uninsured deposit financing.

Finally, it is worth noting that the above two patterns also help confirm our earlier conjecture (see section 4.2) that customer relationships are unlikely to confound our inferences. Specifically, it is not clear why switching costs would matter more for depositors' withdrawal decisions when there is less peer capital available, or when \%Uninsured is higher.

\subsubsection{Controlling for informational properties of $R O A$}

In our last set of analyses, we explicitly measure the informational properties and control for them in our regressions. A unit increase in ROA can result in a larger upward revision of beliefs about asset values if it is more persistent (i.e., more likely to repeat in future) and/or if it provides a more precise signal about changes in asset values. The latter follows from the Bayesian updating rule under which depositors put more weight on more precise signals to update their beliefs about asset values.

We measure earnings persistence (Persistence) for each bank-quarter as the slope coefficient from an $\mathrm{AR}(1)$ regression of $R O A_{t}$ estimated over the previous 12 quarters. Our measure of earnings precision (Informativeness) comes from Chen et al. (2022) and captures the ability of earnings and its components to predict future write-offs, as assessed by the adjusted $R$ squared of the prediction regression estimated over the preceding 12 quarters. We refer readers to the Appendix of this paper and to Chen et al. (2022) for more details on this measure. Chen et al. 
(2022) find that uninsured deposit flows are indeed more responsive to earnings of bank with greater Informativeness.

Table 6, Panel A presents the results by including Persistence and Informativeness, as well as their interactions with $R O A$ in the sensitivity specification. As expected, estimates in columns (1) to (3) indicate that uninsured deposits exhibit greater sensitivity to performance for banks with greater persistence and informativeness. More importantly, the coefficient on the interaction of Asset Illiquidity with ROA continues to be significant in all columns. For example, in column (3) where both Persistence and Informativeness and their interactions with ROA are included simultaneously, we find that the effect of asset illiquidity on flow-performance sensitivity continues to be significant with large magnitude: a one-standard-deviation increase in Asset illiquidity is associated with a nearly $30 \%$ increase in flow-performance sensitivity.

Estimates in columns (4)-(6) show that our inferences from the level specification are also similarly robust. For example, the coefficient on Asset Illiquidity $\times I_{R O A<M e d}$ is negative and significant (coef=-4.682; $p$-value $<0.01$ ) in column (6) when we control for both informational properties. The magnitude implies that a bank with asset illiquidity higher by one standard deviation experiences additional outflows equivalent to $31 \%$ of the mean uninsured deposit flow when performance declines from above- to below-median.

We also confirm the above results in a matched-sample analysis which produces inferences more robust to functional form misspecification. Similar to our matched-sample analysis shown in Table 4 earlier, we propensity-score match the subsamples of observations in the top and the bottom terciles of Asset Illiquidity based on the two informational properties (Precision and Informativness) and other bank characteristics. The idea is to compare two sets of banks that are different in asset illiquidity but similar on all other observables including the informational properties of $R O A$. As before, we use nearest neighbor matching without replacement with a caliper of 0.005 and require common support for the propensity scores across the two groups.

Table 6, Panel B presents covariate balance and shows that the matching is quite successful with no statistically significant differences across all matched variables. Of most interest, the mean values of Persistence (Informativeness) across the two terciles of asset illiquidity are very similar at 0.157 and $0.147(0.211$ and 0.206$)$.

Panel C presents the regression results on the matched sample with an indicator variable ( $I_{\text {High Asset Illiq }}$ ) for membership in the top tercile of Asset Illiquidity as the measure of MisMatch. 
Columns (1) and (2) present the results from the sensitivity analysis, with column (2) modifying the specification in column (1) by explicitly controlling for the effects of persistence and informativeness. As expected, the coefficient estimates on $R O A_{i t-1} \times I_{H i g h}$ Asset Illiq stay relatively unchanged between these two columns, indicating the success of matching. All parameters of interest are statistically significant and economically large: estimates in both columns (1) and (2) imply that the flow-performance sensitivity for banks in the top tercile of Asset Illiquidity is more than double that for banks in the bottom tercile. Similarly, for the level prediction, estimates in columns (3) and (4) imply that compared to a bank in the bottom tercile, a deterioration in performance from above- to below-median for a bank in the top tercile results in additional outflows equivalent to nearly $60 \%$ of the average uninsured flows.

\section{Does deposit insurance help mitigate the uninsured depositor fragility?}

A key policy tool - first introduced in 1934 - to address panic is deposit insurance. In this section, we explore the efficacy of deposit insurance in helping banks manage the fragility of their uninsured deposit base. There are two ways this can occur. When performance at a high MisMatch bank deteriorates, concerned uninsured depositors can split deposit balances across different banks to ensure they fall within the deposit insurance limits, leading to an increase in insured deposit balances. The other possibility is that banks with high MisMatch offer higher rates in times of poor performance to attract insured deposits from other banks. Prior work suggests that banks indeed actively attract insured deposits in times of poor performance by offering higher rates (Billett et al. 1998; Martin et al. 2018; Chen et al. 2022). It is worth noting that the deposit rate mechanism can even lead to an increase in total deposits at high MisMatch banks if a sufficiently large mass of insured depositors - unconcerned about the greater default risk at high mismatch banks - leaves low mismatch banks to chase higher rates; as we discuss below, we find some evidence of this phenomenon.

Table 7 presents the results of this analysis for both the sensitivity (Panel A) and the level specifications (Panel B). For ease of comparison, columns (1) and (4) reproduce the results for uninsured deposit flows using Asset Illiquidity and \%Uninsured as the proxy for MisMatch. Columns (2) and (5) present the results with insured deposit flows as the dependent variable. Consistent with insured deposits serving as substitute for uninsured deposits, the coefficient on MisMatch $\times R O A$ is negative and significant when using both Asset Illiquidity (coef=-2.234; $p$ value $<0.1$ ) and \%Uninsured (coef=-0.055; $p$-value $<0.01$ ) as measures of MisMatch. The next 
question is to what degree insured deposits offset the sensitivity of uninsured deposits. The evidence is mixed and depends on the measure of MisMatch. For Asset Illiquidity, the sensitivity is only partly offset: estimates in column (3) show that the sensitivity of total deposits continues to increase with the degree of Asset Illiquidity (coef=1.531; $p$-value $<0.01$ ), suggesting that despite their effort to substitute uninsured with insured deposits in times of poor performance, banks with more Asset Illiquidity still experience larger loss of total deposits. Estimates in column (6), however, show that insured deposits more than make-up for the loss of uninsured deposits when we use \%Uninsured as the mismatch measure: the coefficient on interaction term is negative and significant (coef=-0.010; $p$-value $<0.05)$.

The inferences are similar when we analyze the level of uninsured deposit flows in Panel B. Consistent with insured deposits substituting for the loss of uninsured deposits, columns (2) and (5) show that the coefficients on MisMatch $\times I_{R O A<M e d}$ are positive for insured deposit flows for both measures of mismatch. When modelling total deposit flows: the coefficient on the interaction term is negative when using Asset Illiquidity but turns positive when using \%Uninsured as the proxy for mismatch. This suggests that the gain in insured deposits is not enough to make up for the loss of uninsured deposits when using Asset Illiquidity as the proxy for MisMatch but more than makes up for the loss when using \%Uninsured as the proxy for MisMatch.

Finally, we explore whether the above results, at least partly, reflect the effect of differential rate increases at high and low MisMatch banks. Panels C and D present the results from estimation of similar specifications as above except with the natural logarithm of large timeand core-deposit rates as the dependent variables. Because we are modelling banks' response in the form of deposit rates, we do not control for lagged deposit rates in these regressions. Across all specifications, we find strong evidence that banks with greater MisMatch respond with larger rate increases in response to decline in performance. The magnitudes of rate increases are meaningful. For example, in the level specification in Panel B, a one-standard-deviation increase in Asset Illiquidity (\%Uninsured) is associated with nearly 5\% (4.3\%) increase in rates of core deposits - roughly equivalent to 11 (10) basis point increase for an average bank.

Several remarks regarding the implications of above results are in order. First, although banks are (at least partly) successful in substituting uninsured with insured deposits, the substitution is not costless as the banks end up paying higher deposit rates and insurance premium - the substitution merely changes the nature of costs incurred because of strategic 
complementarities. Second, to our knowledge, these findings provide the first micro-level large sample evidence on the efficacy of deposit insurance in mitigating the effects of panic-based withdrawals. The evidence is important considering the non-trivial costs of running a government sponsored deposit insurance program in the form of underpriced insurance, administrative costs, and perhaps most importantly, the costs in the form of increased moral hazard in the banking industry (e.g., Billett et al, 1998). These costs would be lowered (if not eliminated) if panic-based uninsured deposit withdrawals were not an economically important phenomenon.

Finally, these results inform the growing body of work on the trade-offs of production of safe, money-like claims by the private (i.e., banks) vs. the public (i.e., government) sector. As highlighted in Gorton and Metrick (2012) and Gorton (2017), safe, money-like claims could be produced either through the backing of the taxing authority of the government (e.g., treasury bills, insured deposits) or purely in the private sector (i.e., without any government support) through the backing of banks' assets (i.e., uninsured deposits). The literature highlights that there are costs associated with government production of safe claims and thus there is social value in the production of safe assets by the private sector. ${ }^{23}$ Our findings indicate that strategic complementarities place economically important bounds on the private sector's ability to produce safe claims - for banks with high strategic complementarities, uninsured deposits lose their perceived safety more easily (even if the bank is financially solvent) and get replaced by government backed safe claims in the form of insured deposits. Given that there are costs to the production of safe claims that are backed by the government, the substitution between uninsured and insured deposits is not expected to be welfare-neutral.

\section{Implications for systemic fragility}

When thinking about the implications of liquidity mismatch, a key concern pertains to systemic fragility. We provide two analyses that show how liquidity mismatch can contribute to industry-wide fragility by magnifying the effect of systematic weaknesses - a feature shown in a recent model by Goldstein et al. (2022). The results from these analyses also lend further support to our earlier inferences regarding depositor behavior reflecting an element of panic.

\footnotetext{
${ }^{23}$ Holmstrom and Tirole $(1998,2011)$ argue that deadweight costs of distortionary taxes will limit the government supply of safe claims. Tirole (2010, Chapter 5) shows that consumer risk aversion will further limit the supply of government liquidity even in the absence of deadweight costs of taxation.
} 


\subsection{Systematic and idiosyncratic earnings}

We first explore whether the effect of the liquidity mismatch differs when the performance shock is systematic vs. when it is idiosyncratic. Holding the magnitude of the performance shock constant, we expect depositors' incentive to run before others to be stronger in response to a systematic performance shock (i.e., when the entire industry is suffering) than when the shock is idiosyncratic. When the entire industry is experiencing poor performance, assets sell at a higher fire sale discount (Shleifer and Vishny, 1992) and banks are less likely to lend to other banks (Liu, 2016). Therefore, depositors know that in periods of systematic distress banks will have greater difficulty in meeting short term spikes in deposit withdrawals by accessing interbank markets and/or by liquidating assets.

We decompose each bank's $R O A_{\text {it }}$ for every period into a systematic (ROA_Syst $)$ and an idiosyncratic (ROA_Idioit) component. ROA_Syst is calculated as the average ROA for the entire banking sector for quarter $t$ and ROA_Idioit is the difference between $R O A_{i t}$ and ROA_Syst. We then estimate our flow-performance sensitivity regression after including the two components of $R O A$ and their interactive terms with measures of mismatch separately. Table 8, Panel A presents the results. Consistent with depositors being significantly more concerned about the illiquidity of their banks' assets when the performance shock is systematic, the coefficient on the interaction of Asset Illiquidity with ROA_Sys is more than seven times as large as that on the interaction with ROA_Idio (11.682 vs 1.581). The differential impact is similarly large when we use \%Uninsured as the proxy for mismatch: the coefficient on interaction with ROA_Sys is eight times as large as that on the interaction with ROA_Idio (0.160 vs 0.020).

To explore the effects on the level of deposit flows, we examine whether the adverse effect of MisMatch we found in below median region of performance (i.e., the coefficient on MisMatch $\times I_{R O A<M e d}$ from Table 3 ) is driven by periods of adverse systematic or idiosyncratic shocks. We rank observations in the below-median $R O A$ region along two dimensions. We rank them based on the magnitude of ROA_Sys, and characterize them as having bad systematic shock if the ROA_Sys falls below a cutoff value (e.g., in the bottom 1/3, 1/4, or $1 / 5$ of ROA_Sys). Similarly, we also rank them based on ROA_Idio and characterize them as having bad idiosyncratic shock if the ROA_Idio falls below its respective cut-off. We use indicator variables ( $I_{\text {PoorSys \& ROA<Med }}$ or $I_{\text {PoorIdio \& ROA }<\text { Med }}$ ) to identify these observations and include them along with their interactions with MisMatch. The coefficients on these interactions measure how the 
outflows caused by MisMatch in the below-median ROA region vary with the intensity of systematic and idiosyncratic shock.

Table 8, Panel B presents the results for both Asset Illiquidity (columns (1)-(3)) and \%Uninsured (columns (4)-(6)). Columns (1) and (4) presents the results when we use the bottom tercile value as the cutoff to identify bad systematic and idiosyncratic shocks. As expected, the coefficients on interactions of both MisMatch proxies with $I_{\text {Poorsys \& ROA<Med }}$ and $I_{\text {PoorIdio \& } R O A<\text { Med }}$ are negative and significant. More importantly, the magnitude of the effect of a poor systematic shock (compared to idiosyncratic shock) is nearly five times as large when we use Asset Illiquidity (-10.7 vs. -2.2) and more than six times when we use \%Uninsured (-0.13 vs. -0.02) as the MisMatch measure. Estimates in remaining columns show that these inferences are robust to using bottom quartile or quintile as the cutoffs to identify bad shocks.

A potential concern is that periods of systematic distress may coincide with increased demand for liquidity by consumers. Perhaps it is the case that stronger withdrawals in response to systematic shocks reflects heightened liquidity needs and not panic. We emphasize that this possibility can account for these results only if crises systematically have a stronger impact on the liquidity needs of individuals residing in regions where banks with more liquidity mismatch are located. We are not aware of any empirical finding or theoretical reason to expect this to be the case. Nevertheless, to mitigate this concern, we repeat the above analyses but restricting our sample to observations from single-state banks (i.e., banks with branches located in only one state). We use statexyear-quarter interactive fixed effects to flexibly absorb any state-specific trends in liquidity demand that may coincide with systematic shocks. This way, we obtain estimates by comparing banks with varying levels of liquidity mismatch operating in the same state. Results presented in Table A3 of the Online Appendix show that our inferences remain intact.

Overall, the above results lend additional support to our earlier inferences and highlight how liquidity mismatch can magnify systemic weakness to contribute to industry-wide fragility.

\subsection{Liquidity mismatch and the 2008 Financial Crisis}

We next use the 2008 Financial Crisis as a laboratory to observe the differential impact of an episode of crisis on banks with varying levels of liquidity mismatch. We estimate the following difference-in-differences style specification:

$$
\mathrm{Y}_{\mathrm{it}}=\alpha_{i}+\beta_{t}+\gamma_{1} \text { MisMatch }_{i} \times \text { Crisis }_{t}+\sum_{j} \delta_{j} \text { BankChar }_{i j} \times \text { Crisis }_{t}+\epsilon_{i t},
$$


where $Y_{i t}$ represents an outcome variable for bank $i$ at time $t$ and Crisis $_{t}$ is an indicator variable for the crisis period of 2007Q3 to 2009Q2. MisMatch and all the bank characteristics we control for (BankChar) are measured as of the quarter just before the onset of the crisis. ${ }^{24} \alpha_{i}$ and $\beta_{t}$ represent bank and year-quarter fixed effects. Because MisMatch and BankChar are time-invariant, their main effects are subsumed by bank fixed effects. The key coefficient of interest is $\gamma_{1}$ which measures the differential impact of crisis on banks with varying levels of MisMatch. The estimation sample includes data for up to 5 years prior to the crisis period and ends with the crisis period. We examine three categories of outcomes: deposit flows, deposit rates, and growth in loans and credit commitments.

Table 9, Panels A and B present the results with Asset Illiquidity and \%Uninsured as the measure of MisMatch, respectively. Columns (1) - (3) in both panels present the results with uninsured, insured, and total deposit flows as the dependent variables. Coefficient estimates on MisMatch $\times$ Crisis show that banks with higher liquidity mismatch experience larger uninsured deposit outflows during the crisis, which they are unable to completely make up for using insured deposits flows, resulting in lower total deposit flows. Columns (4) and (5) model banks' deposit rate response and yield some evidence (the results are significant only for Asset Illiquidity) that the adverse deposit flow outcomes occur despite high MisMatch banks offering greater interest rates during the crisis. Finally, in columns (6) and (7) we model growth in loans and credit commitments to examine whether the funding pressure faced by high MisMatch banks manifests in lending outcomes. Both Panels A and B find strong evidence that banks with higher MisMatch experience slower growth in loans and commitments during the crisis: a one-standard-deviation increase in pre-crisis Asset Illiquidity (\%Uninsured) is associated with an additional adverse impact of $2.8 \%(1.1 \%)$ on loan growth and $1.2 \%(1 \%)$ on commitments. As a benchmark, the average growth in loans and in commitments in our sample is $4.5 \%$ and $1 \%$, respectively.

\section{Conclusions}

In this paper, we examine the effect of the amount of liquidity transformation conducted by banks on the outflows of their uninsured deposits. Banks that provide more liquidity transformation experience higher sensitivity of uninsured deposit flows to performance and greater

\footnotetext{
${ }^{24}$ All controls are measured prior to the crisis to avoid the well-known "bad-control” problem (e.g., Angrist and Pischke, 2009, pp. 64-66). Because the controls are also affected by the crisis, introducing time-varying controls can bias estimates and even take away the effect of interest.
} 
levels of uninsured deposit outflows when they perform poorly. Results from a battery of tests indicate that the withdrawal decisions of uninsured deposits are not purely driven by fundamentals but reflect an element of panic. While banks utilize deposit insurance to mitigate the impact of fragility - by raising deposit rates to attract insured deposits to substitute the loss of uninsured deposits when their performances decline - they are still prone to fragility. Finally, the effects of liquidity transformation are exacerbated when the aggregate conditions in the banking system are unfavorable. Our results are consistent with the theoretical predictions of Goldstein and Pauzner (2005). As in their model, we show that fundamentals are important for explaining bank runs, but in addition, an element of panic amplifies withdrawals due to the bank’s liquidity creation.

\section{References}

Acharya, V.V. and Mora, N., 2015. A crisis of banks as liquidity providers. Journal of Finance, 70(1), pp.1-43.

Allen, F., Carletti, E., Goldstein, I. and Leonello, A., 2018. Government guarantees and financial stability. Journal of Economic Theory, 177, pp.518-557.

Allen, F. and Gale, D., 1998. Optimal financial crises. The Journal of Finance, 53(4), pp.12451284.

Angrist, J.D. and Pischke, J.S., 2009. Mostly harmless econometrics: An empiricist's companion. Princeton University Press.

Artavanis, N., Paravisini, D., Robles-Garcia, C., Seru, A. and Tsoutsoura, M., 2019. Deposit Withdrawals. Working paper.

Badertscher, B.A., Burks, J.J. and Easton, P.D., 2018. The market reaction to bank regulatory reports. Review of Accounting Studies, 23(2), pp.686-731.

Bagehot, W. 1873. Lombard Street: A Description of the Money Market, CreateSpace Independent Publishing Platform.

Bai, J. Krishnamurthy and Weymuller, C. 2018. Measuring liquidity mismatch in the banking sector. Journal of Finance, 73(1), pp. 51-93.

Benston, G. J., and Kaufman, G., 1997. FDICIA after Five Years. Journal of Economic Perspectives, 11 (3): pp. 139-158.

Berger, A.N. and Bouwman, C.H., 2009. Bank liquidity creation. Review of Financial Studies, 22(9), pp.3779-3837.

Bernard, V.L. and Thomas, J.K., 1989. Post-earnings-announcement drift: delayed price response or risk premium? Journal of Accounting Research, pp.1-36.

Billett, M.T., Garfinkel, J.A. and O'Neal, E.S., 1998. The cost of market versus regulatory discipline in banking. Journal of Financial Economics, 48(3), pp.333-358.

Brown, M., Guin, B. and Morkoetter, S., 2020. Deposit withdrawals from distressed banks: Client relationships matter. Journal of Financial Stability, 46, p.1007.

Chari, V.V. and Jagannathan, R., 1988. Banking panics, information, and rational expectations equilibrium. Journal of Finance, 43(3), pp.749-761.

Chevalier J. and Ellison E. 1997. Risk taking by mutual funds as a response to incentives. Journal of Political Economy, 105(6), pp. 1167-1200. 
Chen, Q., Goldstein, I., Huang, Z., and Vashishtha, R., 2022. Bank transparency and deposit flows. Journal of Financial Economics, 146(2), pp. 475-501.

Chen, Q., Goldstein, I. and Jiang, W., 2010. Payoff complementarities and financial fragility: Evidence from mutual fund outflows. Journal of Financial Economics, 97(2), pp. 239-262.

Dávila, E. and Goldstein, I., 2022. Optimal deposit insurance. Journal of Political Economy forthcoming.

Demirguc-Kunt, A. and Detragiache, E. 1998. The determinants of banking crisis: evidence from developed and developing countries. IMF Staff Papers 45, 81-109.

Demirguc-Kunt, A. and Detragiache, E. 2002. Does deposit insurance increase banking system stability? An empirical investigation. Journal of Monetary Economics, 49, pp. 1373-1406.

Diamond, D.W. and Dybvig, P.H., 1983. Bank runs, deposit insurance, and liquidity. Journal of Political Economy, 91(3), pp. 401-419.

Drechsler, I., Savov, A. and Schnabl, P., 2017. The deposits channel of monetary policy. The Quarterly Journal of Economics, 132(4), pp.1819-1876.

Egan, M., Hortaçsu, A. and Matvos, G., 2017. Deposit competition and financial fragility: Evidence from the U.S. banking sector. American Economic Review, 107(1), pp.169-216.

Federal Financial Institutions Examination Council, 2000. Uniform retail credit classification and account measurement policy.

Foley-Fisher, N., Narajabad, B. and Verani, S., 2020. Self-fulfilling runs: Evidence from the US life insurance industry. Journal of Political Economics, 128(9), pp. 3520-3569.

Gatev, E. and Strahan, P.E., 2006. Banks' advantage in hedging liquidity risk: Theory and evidence from the commercial paper market. Journal of Finance, 61(2), pp.867-892.

Goldstein, I., 2013. Empirical literature on financial crises: Fundamentals vs. panic. The Evidence and Impact of Financial Globalization, G. Caprio, ed., Elsevier, pp.523-534.

Goldstein, I., Jiang. H and Ng. D. 2017. Investor flows and fragility in corporate bond funds. Journal of Financial Economics, 126, pp. 592-613.

Goldstein, I., Kopytov, A., Shen, L. and Xiang, H. 2022. Synchronicity and fragility. Working paper.

Goldstein, I. and Pauzner, A., 2005. Demand-deposit contracts and the probability of bank runs. Journal of Finance, 60(3), pp.1293-1327.

Gorton, G., 1988. Banking panics and business cycles. Oxford Economic Papers, 40(4), pp.751781.

Gorton, G., 2017. The history and economics of safe assets. Annual Review of Economics, 9, pp.547-586.

Gorton, G. and Metrick, A., 2012. Securitized banking and the run on repo. Journal of Financial economics, 104(3), pp.425-451.

Granja, J., Matvos, G. and Seru, A., 2017. Selling failed banks. The Journal of Finance, 72(4), pp.1723-1784.

Greene, W.H., 1993. Econometric Analysis. Pearson Hall Publisher.

Herzig-Marx, C., 1978. Bank failures. Economic Perspectives, 2(Mar), pp.22-31.

Holmström, B. and Tirole, J., 1998. Private and public supply of liquidity. Journal of political Economy, 106(1), pp.1-40.

Holmstrom, B. and Tirole, J., 2011. Inside and outside liquidity. MIT press.

Iyer, R. and Puri, M., 2012. Understanding bank runs: The importance of depositor-bank relationships and networks. American Economic Review, 102(4), pp.1414-45. 
Iyer, R., Puri, M. and Ryan, N., 2016. A tale of two runs: Depositor responses to bank solvency risk. Journal of Finance, 71(6), pp.2687-2726.

Jacklin, C.J. and Bhattacharya, S., 1988. Distinguishing panics and information-based bank runs: Welfare and policy implications. Journal of Political Economy, 96(3), pp.568-592.

Keister, T., 2016. Bailouts and financial fragility. The Review of Economic Studies, 83(2), pp.704736.

Liu, X. 2016. Interbank market freezes and creditor runs. The Review of Financial Studies, 29(7), pp.1860-1910.

Lin, L., 2020. Bank deposits and the stock market. The Review of Financial Studies, 33(6), pp.2622-2658.

Martin, C., Puri, M. and Ufier, A., 2018. Deposit Inflows and Outflows in Failing Banks: The Role of Deposit Insurance. NBER Working Paper

Morris, S. and Shin, H.S., 2000. Rethinking multiple equilibria in macroeconomic modeling. NBER macroeconomics Annual, 15, pp.139-161.

Robinson, P.M., 1988. Semiparametric econometrics: A survey. Journal of Applied Econometrics, 3(1), pp.35-51.

Rochet, J.C. and Vives, X., 2004. Coordination failures and the lender of last resort: was Bagehot right after all?. Journal of the European Economic Association, 2(6), pp.1116-1147.

Rose, Jonathan D. (2015). “Old-Fashioned Deposit Runs," Finance and Economics Discussion Series 2015-111. Washington: Board of Governors of the Federal Reserve System, http://dx.doi.org/10.17016/FEDS.2015.111.

Schmidt, L., Timmerman A. and Wermers, R. 2016. Runs on money market mutual funds. American Economic Review, 106, pp. 2625-2657.

Schumacher, L. 2000. Bank runs and currency run in a system without a safety net: Argentina and the 'tequila' shock. Journal of Monetary Economics 46, pp. 257-277.

Seber, G.A.F., and Wild, C.J. 1989. Nonlinear Regression. John Wiley \& Sons, Inc.

Shleifer, A. and Vishny, R.W., 1992. Liquidation values and debt capacity: A market equilibrium approach. The Journal of Finance, 47(4), pp.1343-1366.

Tirole, J., 2010. The theory of corporate finance. Princeton university press.

Vives, X. 2014. Strategic complementarities, fragility, and regulation. Review of Financial Studies, 27(12), pp. 3547-3592. 


\section{Figure 1: Illustration of the theoretical underpinning}

This figure summarizes the main result from Goldstein and Pauzner (2005) regarding the withdrawal decisions by depositors in equilibrium. Panel A shows that impatient depositors always withdraw to meet their liquidity needs regardless of bank performance, resulting in an outflow of deposits at level of $-\lambda$. Patient depositors, contributing $1-\lambda$ portion of bank funding, withdraw when they observe a (noisy) signal that indicates the bank's performance is below a threshold of $P^{*}$. Panel B shows that the threshold for withdrawal is higher for banks with higher degree of liquidity mismatch $\left(r_{1}\right)$.

\section{Panel A: Illustration of run regions}

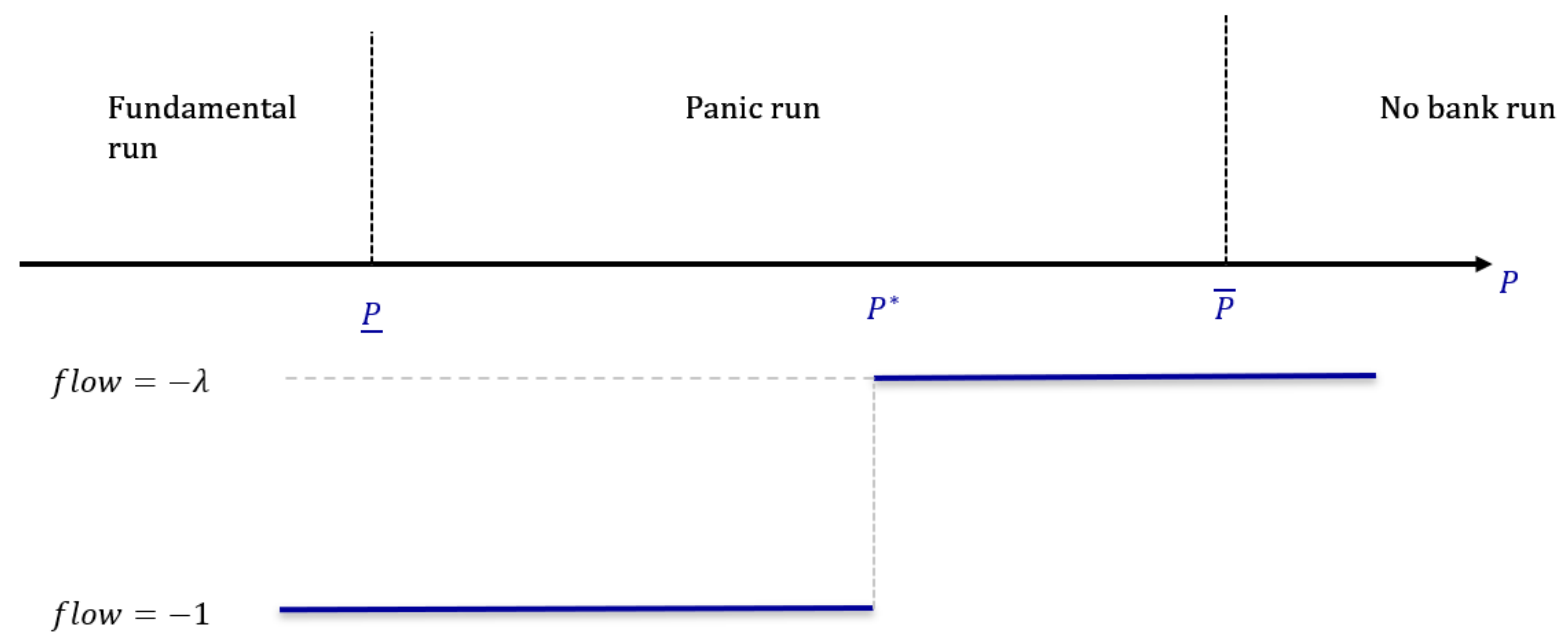

Panel B: Comparison of banks with high and low liquidity mismatch

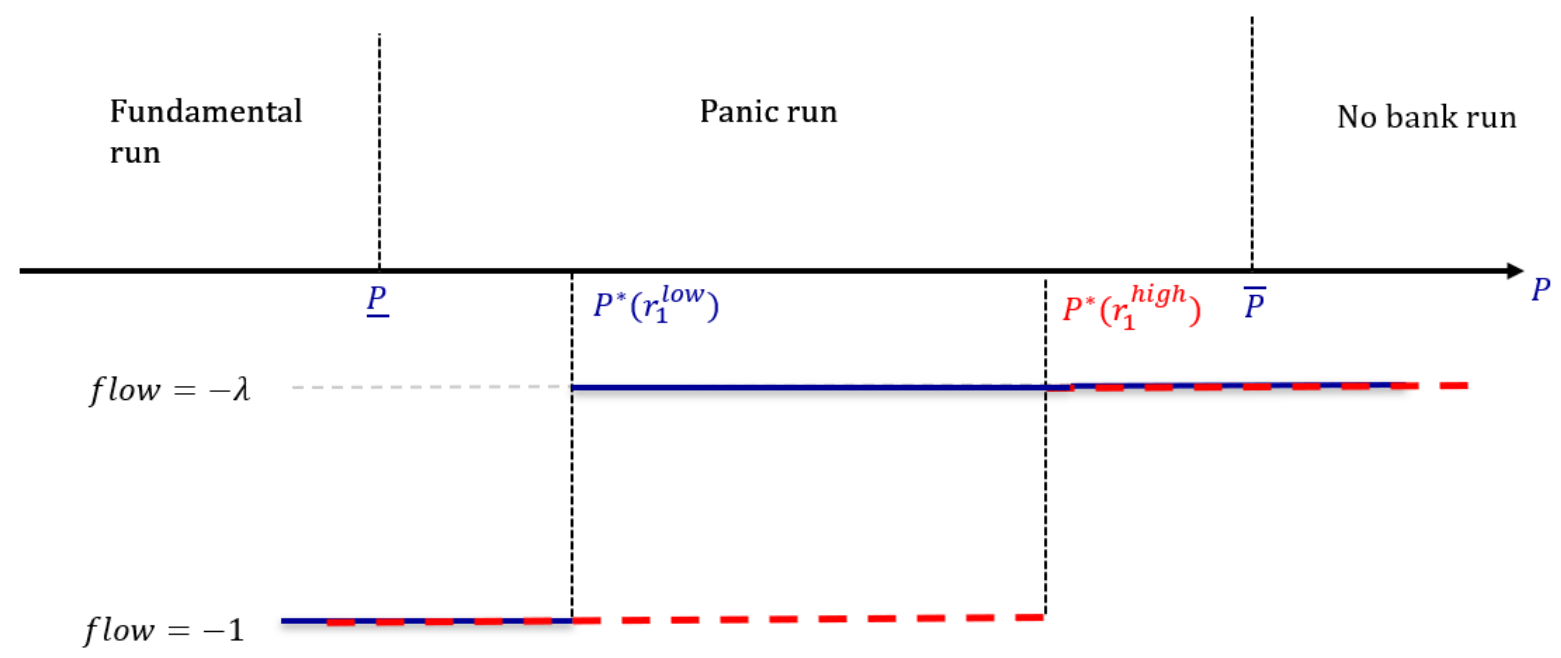




\section{Figure 2: Distribution of ROA for our sample banks}

This figure plots the distribution of $R O A$ (centered on the sample median level) for our sample bank-quarter observations. Because $R O A$ is winsorized at the $1^{\text {st }}$ and $99^{\text {th }}$ percentiles, the distribution in these tails is omitted.

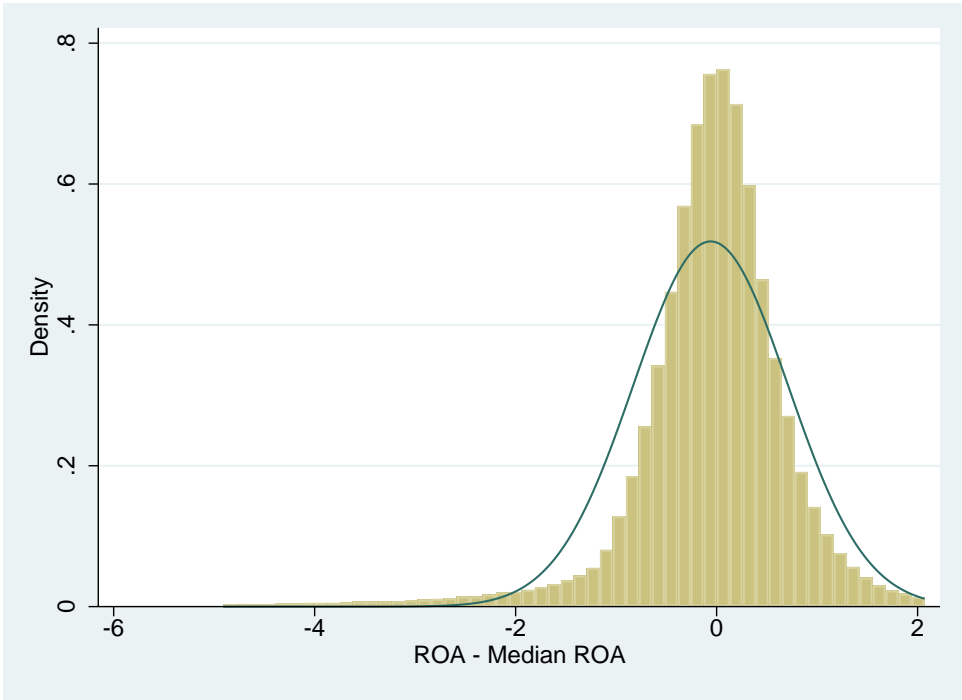

Figure 3: Semi-parametric estimates of the flow-performance relation

This figure illustrates the semi-parametric estimates of the flow-performance relation using the Robinson's (1988) estimator implemented using Gaussian local kernel regressions. The 95\% confidence intervals are shown in dotted lines. $X$-axis plots ROA centered on median (i.e., ROA minus sample median ROA). Y-axis plots the deposit flows. Panel A plots the estimates for insured vs. uninsured deposit flows for the whole sample. Panels B and C plot the estimates for the uninsured deposit flows for banks in the top and bottom terciles of Asset Illiquidity and of \%Uninsured, respectively.

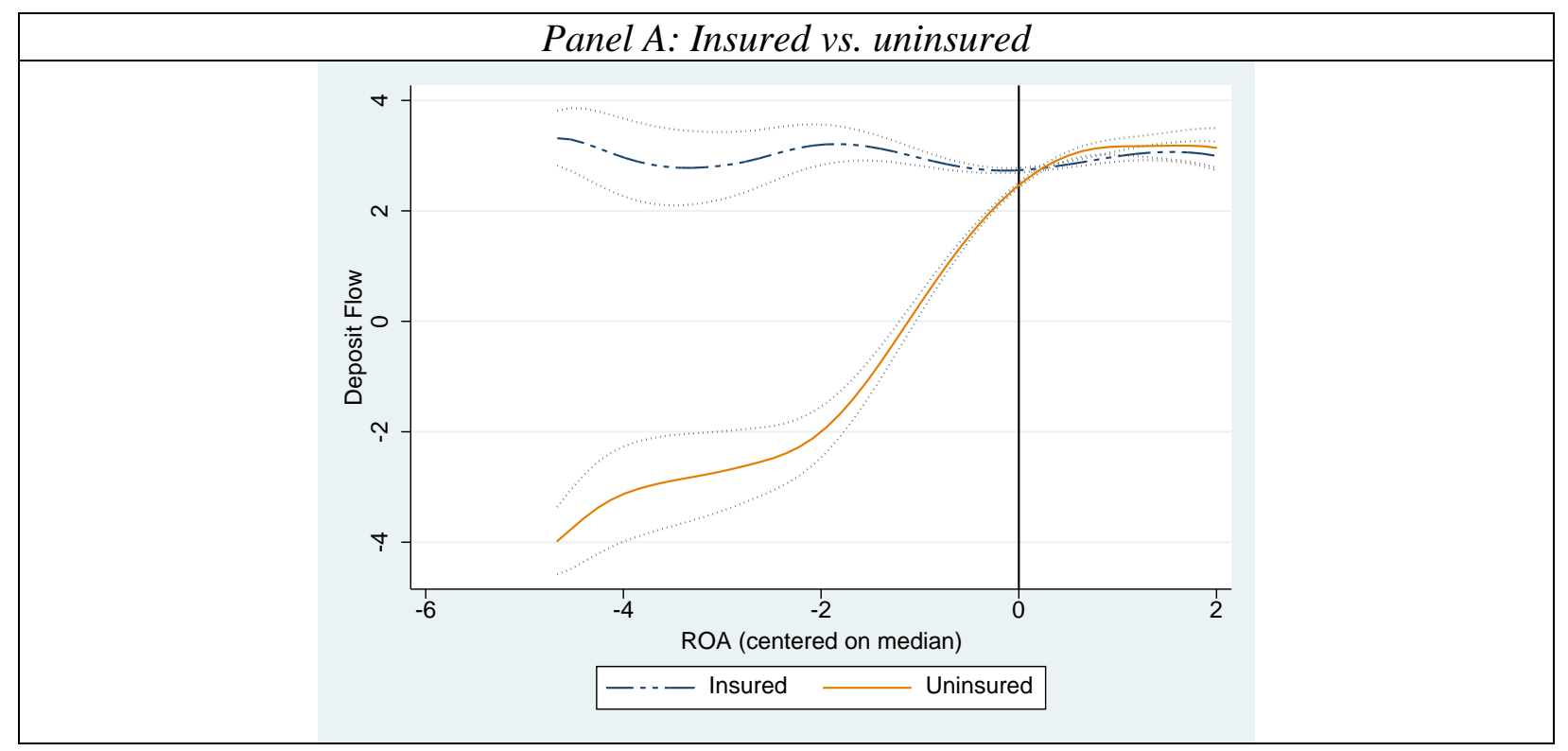




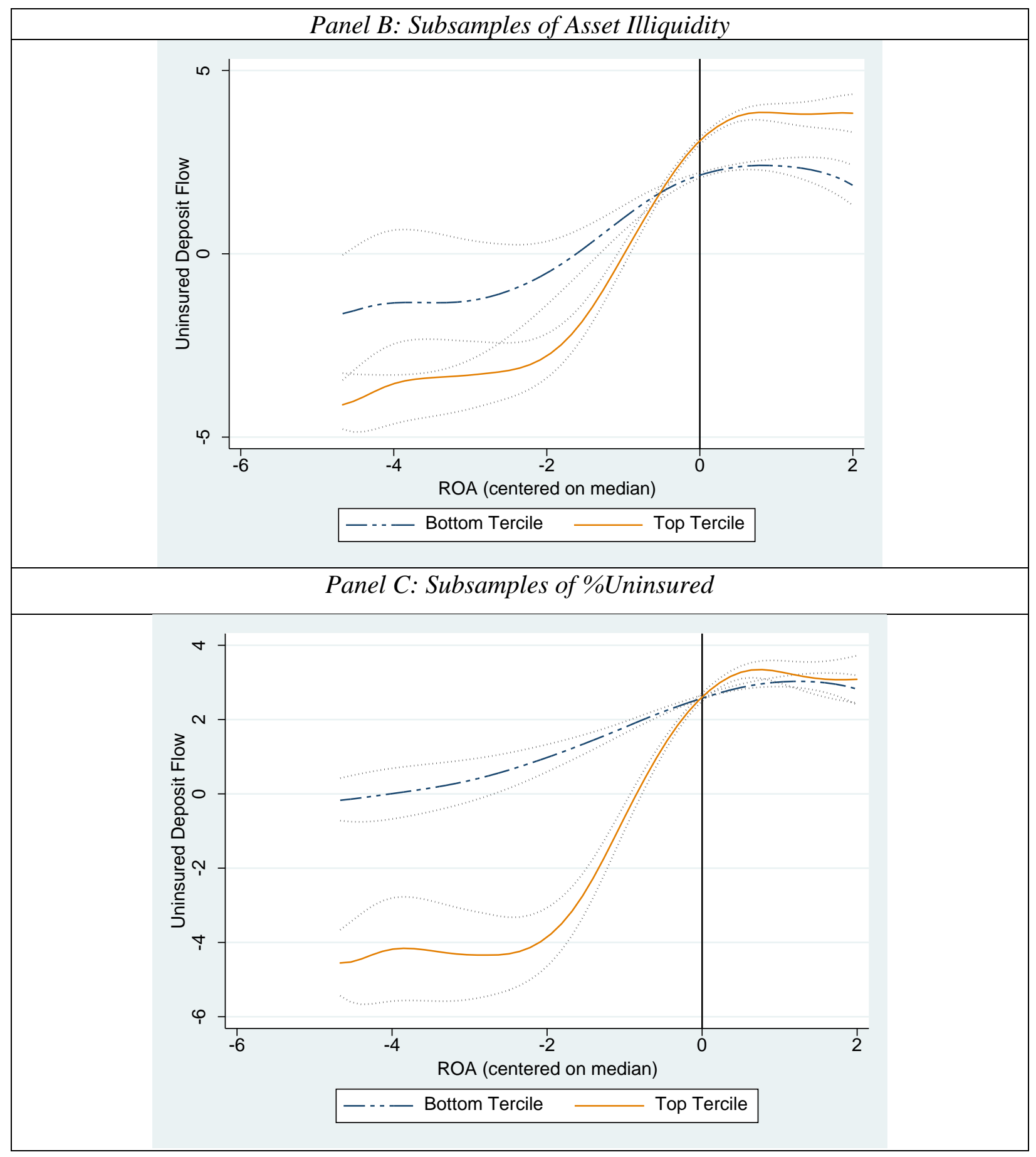


Figure 4: Effect of liquidity mismatch on uninsured deposit flows by deciles of $R O A$

This figure plots the coefficient estimates on MisMatch for each decile of ROA from estimating Eqn. (4). Panels A and B plot the estimates where the measure of Mismatch is Asset Illiquidity and \%Uninsured, respectively. The vertical bar presents the $90 \%$ confidence intervals based on two-way clustered standard errors at the bank and year-quarter level.

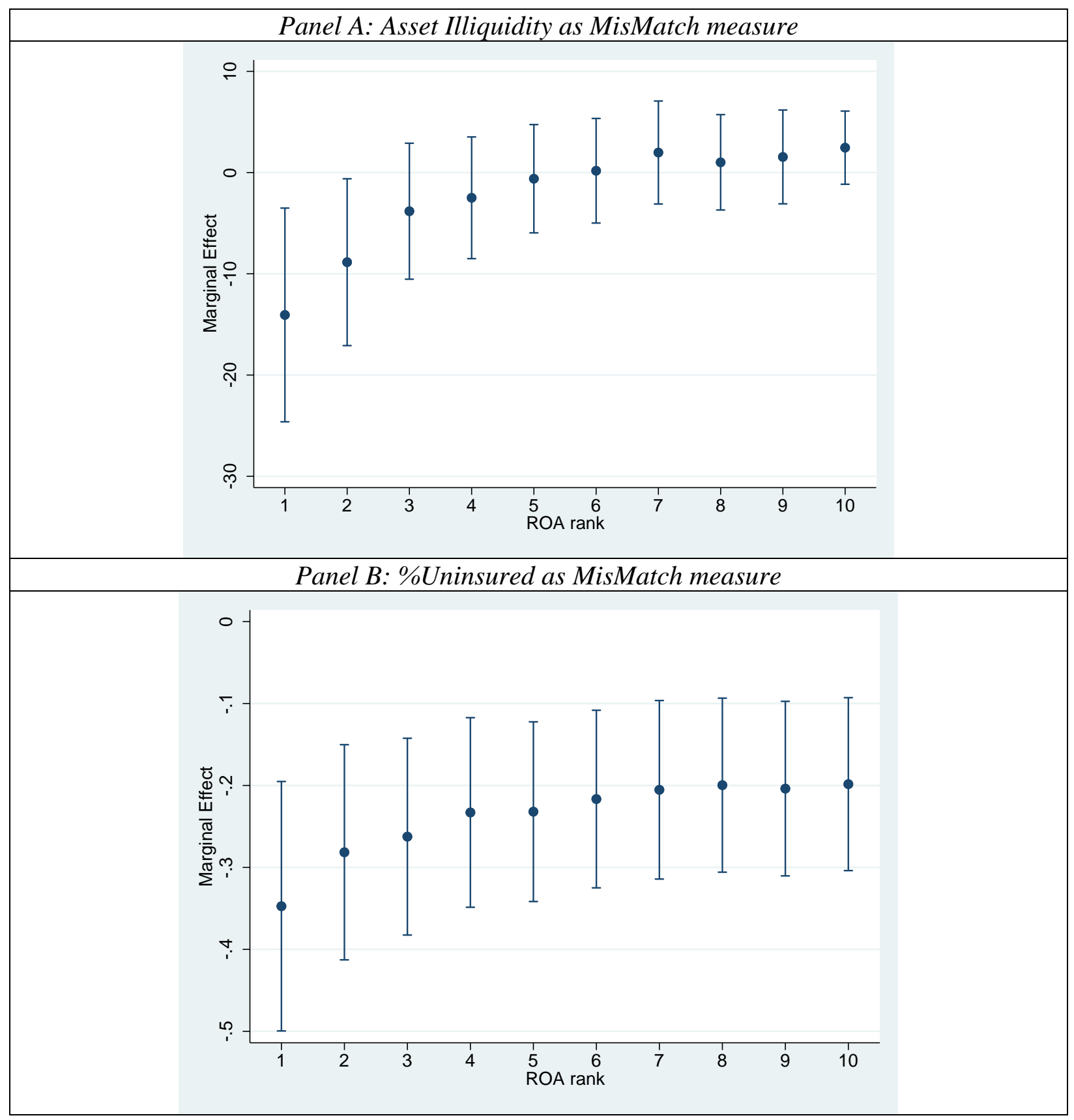




\section{Table 1. Summary statistics}

This table presents summary statistics for the key variables in our analyses. The Appendix contains detailed description of the variable construction. To avoid the impact of mergers and acquisitions, we exclude bankquarter observations with quarterly asset growth greater than $10 \%$. We also exclude observations with total assets less than 100 million. The unit of observation is at commercial bank-quarter level. The final sample includes 8,153 unique commercial banks from 1994 to 2016.

\begin{tabular}{lcccccc}
\hline & $\mathrm{N}$ & Mean & Stdev & P25 & P50 & P75 \\
\hline ROA & 287,018 & 1.00 & 0.90 & 0.70 & 1.08 & 1.44 \\
Asset Illiquidity & 287,018 & 0.07 & 0.14 & -0.02 & 0.08 & 0.18 \\
\%Uninsured (in percentage) & 284,352 & 33.90 & 14.58 & 23.55 & 31.40 & 41.47 \\
$\Delta$ Dep $^{U}$ & 287,018 & 2.12 & 9.92 & -2.04 & 2.16 & 6.84 \\
$\Delta$ Dep $^{I}$ & 287,018 & 2.79 & 9.25 & -1.63 & 1.32 & 5.00 \\
$\Delta$ Dep $^{\text {Total }}$ & 287,018 & 4.78 & 10.60 & -1.48 & 3.87 & 9.93 \\
Core Deposit Rate & 281,816 & 2.21 & 1.40 & 0.98 & 1.96 & 3.40 \\
Large Time Deposit Rate & 281,798 & 3.33 & 1.68 & 1.90 & 3.22 & 4.80 \\
Ln(Assets) & 287,018 & 12.63 & 1.05 & 11.89 & 12.34 & 13.02 \\
C\&I_Loans & 287,018 & 0.16 & 0.10 & 0.09 & 0.14 & 0.20 \\
RealEstate_Loans & 287,018 & 0.69 & 0.17 & 0.60 & 0.72 & 0.82 \\
Wholesale_Funding & 287,018 & 0.20 & 0.10 & 0.12 & 0.19 & 0.26 \\
Capital_Ratio & 287,018 & 0.10 & 0.03 & 0.08 & 0.09 & 0.11 \\
\%Deposits & 287,018 & 0.83 & 0.07 & 0.80 & 0.85 & 0.88 \\
Std(ROE) & 287,018 & 5.30 & 5.82 & 1.93 & 3.21 & 6.07 \\
\hline
\end{tabular}




\section{Table 2. Liquidity mismatch and the flow-performance sensitivity of uninsured deposits}

This table presents evidence on how the flow-performance sensitivity of uninsured depositors is associated with the degree of their banks' liquidity mismatch. Panels A and B present evidence using Asset Illiquidity and \%Uninsured as the respective measure of liquidity mismatch. Interactive controls include the interactive terms between $R O A$ and the demeaned values of time-varying bank characteristics ( $\operatorname{Ln}(\operatorname{Size})$, C\&I Loans, RealEstate_Loans, Wholesale_Funding, Capital_Ratio, \%Deposits, and Std(ROE)). Macro controls include both current and lagged federal fund rates and stock market returns. T-statistics, based on two-way clustered standard errors at the bank and year-quarter level, are presented in the parenthesis below. Statistical significance (two-sided) at the $10 \%, 5 \%$, and $1 \%$ level is denoted by *, **, and ***, respectively.

Panel A: Asset Illiquidity

\begin{tabular}{|c|c|c|c|c|}
\hline Dependent variable & $\Delta D e p_{i t}^{U}$ & $\Delta D e p_{i t}^{U}$ & $\Delta D e p_{i t}^{U}$ & $\Delta D e p_{i t}^{U}$ \\
\hline & $(1)$ & $(2)$ & (3) & $(4)$ \\
\hline$R O A_{i t-1} \times$ Asset Illiquidity $_{i t-1}$ & $\begin{array}{c}2.721^{* *} \\
(2.135)\end{array}$ & & $\begin{array}{c}3.668 * * * \\
(3.179)\end{array}$ & $\begin{array}{c}1.383^{* * *} \\
(4.150)\end{array}$ \\
\hline$R O A_{i t-1}$ & $\begin{array}{c}1.158 * * * \\
(6.403)\end{array}$ & & $\begin{array}{c}1.499 * * * \\
(4.817)\end{array}$ & $\begin{array}{c}0.787 * * * \\
(11.365)\end{array}$ \\
\hline Asset Illiquidity $_{i t-1}$ & $\begin{array}{c}-1.495 \\
(-0.710)\end{array}$ & $\begin{array}{c}-1.671 \\
(-0.817)\end{array}$ & $\begin{array}{c}-6.417 \\
(-1.363)\end{array}$ & $\begin{array}{c}1.853 * * * \\
(2.695)\end{array}$ \\
\hline ROA1 $_{i t-1} \times$ Asset Illiquidity $_{i t-1}$ & & $\begin{array}{c}3.953 * * * \\
(2.717)\end{array}$ & & \\
\hline ROA2 ${ }_{i t-1} \times$ Asset Illiquidity $_{i t-1}$ & & $\begin{array}{c}0.300 \\
(0.235)\end{array}$ & & \\
\hline ROA1 ${ }_{i t-1}$ & & $\begin{array}{c}1.703^{* * *} \\
(4.544)\end{array}$ & & \\
\hline ROA2 it-1 & & $0.525 * * *$ & & \\
\hline
\end{tabular}

\section{Control Variables}

Ln(Size $)_{i t-1}$

C\&I_Loans it-1

0.014
$5.280^{* * *}$
$1.724 * *$
0.331

0.002

$-2.948 * * *$

$-3.541 * * *$

RealEstate_Loans ${ }_{i t-1}$

$5.637 * * *$

1.285

0.239

Wholesale_Funding ${ }_{i t-1}$

$2.144^{* * *}$

$-0.992$

$-1.089$

Capital_Ratio ${ }_{i t-1}$

$13.588 * * *$

0.753

3.840

$9.863 * * *$

\%Deposits it-1

$6.376 * * *$

$14.707^{* * *}$

$49.220 * * *$

$45.270 * * *$

Std(ROE) $)_{i t-1}$

$-0.047 * * *$

$6.562 * * *$

$12.705^{* * *}$

$8.668 * * *$

Large Time Deposit Rate

$-0.333 *$

$-0.014$

$-0.053 * * *$

$-0.056 * * *$

Core Deposit Rate ${ }_{t-1}$

$-0.506$

$-0.336 *$

$-0.333^{*}$

$-0.039$

$-0.503$

$-1.007^{*}$

$0.159 * *$

Interactive controls

Macro controls

$\mathrm{Y}$
$\mathrm{Y}$
$\mathrm{N}$

\section{Y}

Y

$\mathrm{N}$

$\mathrm{Y}$
$\mathrm{Y}$
$\mathrm{Y}$

Y

$\mathrm{N}$

$\mathrm{Y}$ 


\begin{tabular}{lcccc} 
Quarter fixed effects & $\mathrm{N}$ & $\mathrm{N}$ & $\mathrm{N}$ & $\mathrm{Y}$ \\
Observations & 287,018 & 287,018 & 286,831 & 286,831 \\
Adj. R-squared & 0.067 & 0.068 & 0.106 & 0.283 \\
\hline
\end{tabular}

Panel B: \%Uninsured

\begin{tabular}{|c|c|c|c|c|}
\hline Dependent variable & $\Delta D e p_{i t}^{U}$ & $\Delta D e p_{i t}^{U}$ & $\Delta D e p_{i t}^{U}$ & $\Delta D e p_{i t}^{U}$ \\
\hline & $(1)$ & $(2)$ & $(3)$ & $(4)$ \\
\hline$R O A_{i t-1} \times \%$ Uninsured $_{i t-1}$ & $\begin{array}{c}0.039 * * * \\
(3.699)\end{array}$ & & $\begin{array}{c}0.041^{* * *} \\
(3.800)\end{array}$ & $\begin{array}{c}0.022^{* * *} \\
(4.817)\end{array}$ \\
\hline$R O A_{i t-1}$ & $\begin{array}{c}1.149 * * * \\
(6.757)\end{array}$ & & $\begin{array}{c}1.386 * * * \\
(5.059)\end{array}$ & $\begin{array}{c}0.794 * * * \\
(11.127)\end{array}$ \\
\hline${ }_{\text {oUninsured }}{ }_{i t-1}$ & $\begin{array}{c}-0.083 * * \\
(-2.264)\end{array}$ & $\begin{array}{c}-0.082 * * \\
(-2.291)\end{array}$ & $\begin{array}{c}-0.287 * * * \\
(-3.594)\end{array}$ & $\begin{array}{c}-0.220 * * * \\
(-12.423)\end{array}$ \\
\hline$R O A 1_{i t-1} \times \%$ Uninsured ${ }_{i t-1}$ & & $\begin{array}{c}0.055^{* * *} \\
(4.002)\end{array}$ & & \\
\hline$R O A 2_{i t-1} \times \%$ Uninsured $_{i t-1}$ & & $\begin{array}{c}-0.004 \\
(-0.478)\end{array}$ & & \\
\hline$R O A 1_{i t-1}$ & & $\begin{array}{c}1.555^{* * *} \\
(4.813)\end{array}$ & & \\
\hline ROA2 it-1 & & $\begin{array}{c}0.697 * * * \\
(6.027)\end{array}$ & & \\
\hline \multicolumn{5}{|l|}{ Control Variables } \\
\hline $\operatorname{Ln}(\text { Size })_{i t-1}$ & $0.257 * *$ & $0.229 *$ & $-1.919 * * *$ & $-2.735 * * *$ \\
\hline C\&I_Loans it-1 & $8.701 * * *$ & $8.794 * * *$ & $3.617 * * *$ & $2.493^{* *}$ \\
\hline RealEstate_Loans $_{i t-1}$ & $1.948 * *$ & $2.211^{* * *}$ & -0.740 & -0.952 \\
\hline Wholesale_Funding $_{i t-1}$ & $3.503^{* * *}$ & $3.541^{* * *}$ & $12.402 * * *$ & $13.326 * * *$ \\
\hline Capital_Ratio $_{i t-1}$ & $16.895^{* * *}$ & $18.487 * * *$ & $50.050 * * *$ & $49.003^{* * *}$ \\
\hline$\%$ Deposits ${ }_{i t-1}$ & $6.177^{* * *}$ & $6.237 * * *$ & $10.089 * * *$ & $10.287 * * *$ \\
\hline $\operatorname{Std}(R O E)_{i t-1}$ & $-0.053 * * *$ & $-0.028 *$ & $-0.115^{* * *}$ & $-0.091 * * *$ \\
\hline Large Time Deposit Rate & $-0.338 *$ & $-0.334^{*}$ & $-0.282 *$ & -0.034 \\
\hline Core Deposit Rate Rt- $_{1}$ & -0.544 & -0.536 & $-0.962 *$ & $0.159 * *$ \\
\hline Interactive controls & $\mathrm{Y}$ & $\mathrm{Y}$ & $\mathrm{Y}$ & $\mathrm{Y}$ \\
\hline Macro controls & $\mathrm{Y}$ & $\mathrm{Y}$ & $\mathrm{Y}$ & $\mathrm{N}$ \\
\hline Bank fixed effects & $\mathrm{N}$ & $\mathrm{N}$ & $\mathrm{Y}$ & $\mathrm{Y}$ \\
\hline Quarter fixed effects & $\mathrm{N}$ & $\mathrm{N}$ & $\mathrm{N}$ & $\mathrm{Y}$ \\
\hline Observations & 284,352 & 284,352 & 284,158 & 284,158 \\
\hline Adj. R-squared & 0.072 & 0.074 & 0.135 & 0.294 \\
\hline
\end{tabular}




\section{Table 3. Liquidity mismatch and the level of uninsured deposit flows}

This table presents evidence on how the decline in level of uninsured deposit flows following poor performance varies with the degree of liquidity mismatch. $I_{R O A<M e d}$ is an indicator variable that equals 1 for observations whose $R O A_{i t-1}$ is less than the sample median level of $R O A$, and equals 0 otherwise. Column (1) presents evidence using Asset Illiquidity and column 2 using \%Uninsured as the measure of liquidity mismatch. Interactive controls include the interactive terms between $I_{R O A<M e d}$ and the demeaned values of time-varying bank characteristics (ROA, Ln(Size), C\&I Loans, RealEstate_Loans, Wholesale_Funding, Capital_Ratio, \%Deposits, and Std(ROE)). Macro controls include both current and lagged federal fund rates and stock market returns. T-statistics, based on two-way clustered standard errors at the bank and year-quarter level, are presented in the parenthesis below. Statistical significance (two-sided) at the 10\%, $5 \%$, and $1 \%$ level is denoted by $*$, **, and $* * *$, respectively.

\begin{tabular}{|c|c|c|}
\hline Liquidity mismatch measure & Asset Illiquidity & \%Uninsured \\
\hline \multirow[t]{2}{*}{ Dependent variable } & $\Delta D e p_{i t}^{U}$ & $\Delta D e p_{i t}^{U}$ \\
\hline & $(1)$ & $(2)$ \\
\hline Liquidity MisMatch $_{i t-1} \times I_{R O A<M e d}$ & $\begin{array}{c}-5.281^{* * *} \\
(-3.422)\end{array}$ & $\begin{array}{c}-0.049 * * * \\
(-3.682)\end{array}$ \\
\hline Liquidity MisMatch $_{\text {it- } 1}$ & $\begin{array}{c}0.189 \\
(0.063)\end{array}$ & $\begin{array}{c}-0.224 * * * \\
(-3.289)\end{array}$ \\
\hline$I_{R O A<M e d}$ & $\begin{array}{c}-1.167 * * * \\
(-3.571)\end{array}$ & $\begin{array}{c}-0.843^{* * *} \\
(-2.668)\end{array}$ \\
\hline \multicolumn{3}{|l|}{ Control Variables } \\
\hline$R O A_{i t-1}$ & $0.655^{* * *}$ & $0.763 * * *$ \\
\hline $\operatorname{Ln}(\text { Size })_{i t-1}$ & $-2.618 * * *$ & $-1.773^{* * *}$ \\
\hline C\&I_Loans ${ }_{i t-1}$ & 1.475 & $3.408 * * *$ \\
\hline RealEstate_Loans $_{i t-1}$ & -1.238 & 1.395 \\
\hline Wholesale_Funding ${ }_{i t-1}$ & $11.970 * * *$ & $20.109 * * *$ \\
\hline Capital_Ratio it-1 & $43.749 * * *$ & $40.222 * * *$ \\
\hline$\%$ Deposits $_{i t-1}$ & $18.926 * * *$ & $18.696 * * *$ \\
\hline $\operatorname{Std}(R O E)_{i t-1}$ & $-0.115^{* * *}$ & $-0.155^{* * *}$ \\
\hline Large Time Deposit Rate $_{t}$ & $-0.334 *$ & $-0.285^{*}$ \\
\hline Core Deposit Rate $_{t-1}$ & $-1.031 *$ & $-1.005^{*}$ \\
\hline Interactive controls & $\mathrm{Y}$ & $\mathrm{Y}$ \\
\hline Macro controls & $\mathrm{Y}$ & $\mathrm{Y}$ \\
\hline Bank fixed effects & $\mathrm{Y}$ & $\mathrm{Y}$ \\
\hline Quarter fixed effects & $\mathrm{N}$ & $\mathrm{N}$ \\
\hline Observations & 286,831 & 284,158 \\
\hline Adj. R-squared & 0.106 & 0.134 \\
\hline
\end{tabular}




\section{Table 4. Effects of \%Uninsured on matched sample}

This table explores the effects of \%Uninsured on uninsured deposit fragility on a matched sample of banks. To construct the matched sample, we start with banks in the top and bottom terciles of \%Uninsured. We then propensity-score match the top and the bottom terciles based on covariates that capture banks' asset composition as well as other bank characteristics. Panel A lists the matching covariates and presents evidence on covariate balance of the matched sample. Panel B presents the results for the sensitivity (columns (1) to (2)) and the levels analysis (columns (3) to (4)) where $I_{\text {High \%Unin }}$ is an indicator variable for observations from the matched sample with top tercile value of \%Uninsured. Controls include bank characteristics and the interaction terms of their demeaned values with $R O A$ or $I_{R O A<M e d}$, lagged deposit rates, and macro controls. T-statistics, based on two-way clustered standard errors at the bank and yearquarter level, are presented in the parenthesis below. Statistical significance (two-sided) at the 10\%, 5\%, and $1 \%$ level is denoted by $*$, ${ }^{*}$, and ${ }^{* * *}$, respectively.

\section{Panel A: Covariate balance}

\begin{tabular}{lccc}
\hline Subsample & $\begin{array}{c}\text { Bottom Tercile } \\
\text { of \%Uninsured }\end{array}$ & $\begin{array}{c}\text { Top Tercile } \\
\text { of \%Uninsured }\end{array}$ & \\
\hline Covariates & Mean & Mean & t-stat of Diff. \\
Asset Illiquidity & 0.076 & 0.076 & -0.002 \\
C\&I_Loans $_{\text {it-1 }}$ & 0.152 & 0.153 & 0.311 \\
RealEstate_Loans $_{\text {it-1 }}$ & 0.709 & 0.708 & -0.109 \\
Wholesale_Funding $_{\text {it-1 }}$ & 0.200 & 0.198 & -0.300 \\
Capital_Ratio $_{\text {it-1 }}$ & 0.099 & 0.099 & 0.203 \\
\%Deposits $_{\text {it-1 }}$ & 0.830 & 0.832 & 0.893 \\
Ln(Size) $_{\text {Std(ROE) }}{ }_{\text {it-1 }}$ & 12.575 & 12.551 & -0.939 \\
\hline
\end{tabular}


Panel B: Effects of \%Uninsured on deposit fragility

\begin{tabular}{|c|c|c|c|c|}
\hline \multirow[b]{2}{*}{ Dependent variable } & \multicolumn{2}{|c|}{ Sensitivity specification } & \multicolumn{2}{|c|}{ Level specification } \\
\hline & $\Delta D e p_{i t}^{U}$ & $\Delta D e p_{i t}^{U}$ & $\Delta D e p_{i t}^{U}$ & $\Delta D e p_{i t}^{U}$ \\
\hline & $(1)$ & $(2)$ & (3) & $(4)$ \\
\hline$R O A_{i t-1} \times I_{\text {High } \% \text { Unin }}$ & $\begin{array}{c}1.654^{* * *} \\
(4.131)\end{array}$ & $\begin{array}{c}1.589 * * * \\
(4.095)\end{array}$ & & \\
\hline$R O A_{i t-1}$ & $\begin{array}{c}0.509 * * * \\
(3.882)\end{array}$ & $\begin{array}{c}0.439 * * * \\
(3.362)\end{array}$ & & \\
\hline$I_{\text {High } \% \text { Unin }} \times I_{R O A<M e d}$ & & & $\begin{array}{c}-2.045^{* * *} \\
(-4.408)\end{array}$ & $\begin{array}{c}-2.012 * * * \\
(-4.330)\end{array}$ \\
\hline$I_{R O A<M e d}$ & & & $\begin{array}{c}0.362 \\
(0.848)\end{array}$ & $\begin{array}{c}0.264 \\
(0.605)\end{array}$ \\
\hline$I_{\text {High \%Unin }}$ & $\begin{array}{c}-5.824 * * * \\
(-3.346)\end{array}$ & $\begin{array}{c}-5.723 * * * \\
(-3.514)\end{array}$ & $\begin{array}{l}-3.295^{* *} \\
(-2.576)\end{array}$ & $\begin{array}{c}-3.295 * * * \\
(-2.791)\end{array}$ \\
\hline$R O A_{i t-1} \times$ Asset Illiquidity $_{i t-1}$ & & $\begin{array}{c}3.375^{* * *} \\
(3.201)\end{array}$ & & \\
\hline Asset Illiquidity $_{i t-1} \times I_{R O A<M e d}$ & & & & $\begin{array}{c}-6.247 * * * \\
(-3.920)\end{array}$ \\
\hline Asset Illiquidity $_{i t-1}$ & & $\begin{array}{c}-3.746 \\
(-1.109)\end{array}$ & & $\begin{array}{c}3.032 \\
(1.478)\end{array}$ \\
\hline Controls & $\mathrm{Y}$ & $\mathrm{Y}$ & $\mathrm{Y}$ & $\mathrm{Y}$ \\
\hline Bank fixed effects & $\mathrm{Y}$ & $\mathrm{Y}$ & $\mathrm{Y}$ & $\mathrm{Y}$ \\
\hline Observations & 92,748 & 92,748 & 92,748 & 92,748 \\
\hline Adj. R-squared & 0.138 & 0.139 & 0.136 & 0.137 \\
\hline
\end{tabular}




\section{Table 5: Variations in the effect of Asset Illiquidity}

This table presents evidence on how the effects of Asset Illiquidity vary by the availability of peer capital (Panel A) and by \%Uninsured (Panel B). In Panels A and B we sort sample into terciles by the amount of peer capital (calculated following the procedure in Granja et al, 2017) and by the bank's \%Uninsured, respectively. Columns (1) to (3) in each panel present the results from a pooled estimation of Eqn. (3) while allowing the effects of Asset Illiquidity on flow-performance sensitivity to vary by tercile. Columns (4) to (6) in each panel present the results from a pooled estimation of Eqn. (5) while allowing the coefficients to vary by tercile. Controls include bank characteristics and the interaction terms of their demeaned values with either $R O A$ or $I_{R O A<M e d}$, lagged deposit rates, and macro controls. T-statistics, based on two-way clustered standard errors at the bank and year-quarter level, are presented in the parenthesis below. Statistical significance (two-sided) at the $10 \%, 5 \%$, and $1 \%$ level is denoted by *, **, and $* * *$, respectively.

Panel A: How the effect of Asset Illiquidity varies by the availability of peer capital

\begin{tabular}{|c|c|c|c|c|c|c|}
\hline & \multicolumn{3}{|c|}{ Sensitivity specification } & \multicolumn{3}{|c|}{ Level specification } \\
\hline Tercile rank of Peer Capital & $1^{\mathrm{st}}$ & $2^{\text {nd }}$ & $3^{\text {rd }}$ & $1^{\mathrm{st}}$ & $2^{\text {nd }}$ & $3^{\text {rd }}$ \\
\hline & $(1)$ & $(2)$ & (3) & (4) & (5) & (6) \\
\hline$R O A_{i t-1} \times$ Asset Illiquidity $_{i t-1}$ & $\begin{array}{c}5.535^{* * * *} \\
(3.008)\end{array}$ & $\begin{array}{c}3.266 * * \\
(2.529)\end{array}$ & $\begin{array}{c}1.611^{* * *} \\
(2.781)\end{array}$ & & & \\
\hline$R O A_{i t-1}$ & $\begin{array}{c}2.014 * * * \\
(3.768)\end{array}$ & $\begin{array}{c}1.543^{* * *} \\
(4.270)\end{array}$ & $\begin{array}{c}1.105^{* * *} \\
(6.381)\end{array}$ & & & \\
\hline Asset Illiquidity $_{i t-1} \times I_{R O A<M e d}$ & & & & $\begin{array}{c}-7.630 * * * \\
(-2.854)\end{array}$ & $\begin{array}{c}-5.924 * * * \\
(-2.926)\end{array}$ & $\begin{array}{c}-2.941 * * * \\
(-3.350)\end{array}$ \\
\hline$I_{R O A<M e d}$ & & & & $\begin{array}{c}-1.680 * * * \\
(-3.084)\end{array}$ & $\begin{array}{c}-1.295^{* * *} \\
(-3.491)\end{array}$ & $\begin{array}{c}-0.278 \\
(-0.749)\end{array}$ \\
\hline Asset Illiquidity $y_{i t-1}$ & $\begin{array}{c}-5.826 \\
(-1.082)\end{array}$ & $\begin{array}{c}-6.915 \\
(-1.564)\end{array}$ & $\begin{array}{c}-4.634 \\
(-1.539)\end{array}$ & $\begin{array}{c}3.625 \\
(1.254)\end{array}$ & $\begin{array}{c}-0.517 \\
(-0.194)\end{array}$ & $\begin{array}{c}-0.944 \\
(-0.364)\end{array}$ \\
\hline Controls & & $\mathrm{Y}$ & & & $\mathrm{Y}$ & \\
\hline Bank fixed effects & & $\mathrm{Y}$ & & & $\mathrm{Y}$ & \\
\hline Observations & & 214,029 & & & 214,029 & \\
\hline Adj. R-squared & & 0.122 & & & 0.121 & \\
\hline Test of difference: Top Tercile - & ottom Tercil & & & & & \\
\hline$R O A_{i t-1} \times$ Asset Illiquidity $_{i t-1}$ & & $\begin{array}{c}\text { Diff } \\
-3.924^{* *} \\
(2.056)\end{array}$ & & . & Diff & \\
\hline Asset Illiquidity $_{\text {it- } 1} \times I_{R O A<M e d}$ & & & & & $\begin{array}{l}4.688^{*} \\
(1.746)\end{array}$ & \\
\hline
\end{tabular}


Panel B: How the effect of Asset Illiquidity varies by \%Uninsured

\begin{tabular}{|c|c|c|c|c|c|c|}
\hline \multirow[b]{2}{*}{ Tercile rank of \%Uninsured } & \multicolumn{3}{|c|}{ Sensitivity specification } & \multicolumn{3}{|c|}{ Level specification } \\
\hline & $1^{\text {st }}$ & $2^{\text {nd }}$ & $3^{\text {rd }}$ & $1^{\text {st }}$ & $2^{\text {nd }}$ & $3^{\text {rd }}$ \\
\hline & $(1)$ & $(2)$ & (3) & (4) & (5) & $(6)$ \\
\hline$R O A_{i t-1} \times$ Asset Illiquidity $_{i t-1}$ & $\begin{array}{l}1.593 * * * \\
(3.199)\end{array}$ & $\begin{array}{c}2.348 * * * \\
(3.608)\end{array}$ & $\begin{array}{l}4.045^{* *} \\
(2.432)\end{array}$ & & & \\
\hline$R O A_{i t-1}$ & $\begin{array}{c}0.752 * * * \\
(4.921)\end{array}$ & $\begin{array}{c}1.220 * * * \\
(4.621)\end{array}$ & $\begin{array}{c}2.003 * * * \\
(5.002)\end{array}$ & & & \\
\hline Asset Illiquidity $_{i t-1} \times I_{R O A<M e d}$ & & & & $\begin{array}{c}-2.017 * * * \\
(-3.369)\end{array}$ & $\begin{array}{c}-3.563 * * * \\
(-3.578)\end{array}$ & $\begin{array}{c}-7.949 * * * \\
(-2.837)\end{array}$ \\
\hline$I_{R O A<M e d}$ & & & & $\begin{array}{c}-0.252 \\
(-0.806)\end{array}$ & $\begin{array}{l}-0.775^{* *} \\
(-2.499)\end{array}$ & $\begin{array}{c}-1.890 * * * \\
(-4.133)\end{array}$ \\
\hline Asset Illiquidity $_{i t-1}$ & $\begin{array}{c}0.112 \\
(0.054)\end{array}$ & $\begin{array}{c}-0.711 \\
(-0.233)\end{array}$ & $\begin{array}{c}-6.035 \\
(-1.336)\end{array}$ & $\begin{array}{l}3.252 * \\
(1.786)\end{array}$ & $\begin{array}{c}3.821 \\
(1.650)\end{array}$ & $\begin{array}{c}1.966 \\
(0.970)\end{array}$ \\
\hline Controls & & $\mathrm{Y}$ & & & $\mathrm{Y}$ & \\
\hline Bank fixed effects & & $\mathrm{Y}$ & & & $\mathrm{Y}$ & \\
\hline Observations & & 284,158 & & & 284,158 & \\
\hline Adj. R-squared & & 0.124 & & & 0.122 & \\
\hline \multicolumn{7}{|c|}{ Test of difference: Top Tercile - Bottom Tercile } \\
\hline$R O A_{i t-1} \times$ Asset Illiquidityit-1 & & $\begin{array}{c}\text { Diff } \\
2.452 \\
(1.560)\end{array}$ & & . & Diff & \\
\hline Asset Illiquidity $_{i t-1} \times I_{R O A<M e d}$ & & & & & $\begin{array}{r}-5.932 * * \\
(-2.073)\end{array}$ & \\
\hline
\end{tabular}




\section{Table 6: Controlling for differences in informational properties of $\mathrm{ROA}$}

This table explores whether the effect of asset illiquidity on uninsured deposit fragility is robust to inclusion of controls for the informational properties of ROA. Panel A presents the results for the full sample. Panels $\mathrm{B}$ and $\mathrm{C}$ present the results on the matched sample. To construct the matched sample, we start with banks in the top and bottom terciles of Asset Illiquidity. We then propensity-score match the top and the bottom terciles based on covariates shown in the covariate list of Panel B. Panel C presents the results from the sensitivity and level specifications on the matched sample where $I_{\text {High Asset Illiq }}$ is an indicator variable for observations in the top tercile sample. Controls include bank characteristics and the interaction terms of their demeaned values with either $R O A$ or $I_{R O A<M e d}$, lagged deposit rates, and macro controls. T-statistics, based on two-way clustered standard errors at the bank and year-quarter level, are presented in the parenthesis below. Statistical significance (two-sided) at the $10 \%, 5 \%$, and $1 \%$ level is denoted by *, ${ }^{* *}$, and ${ }^{* * *}$, respectively.

\section{Panel A: Full sample results}

\begin{tabular}{|c|c|c|c|c|c|c|}
\hline & \multicolumn{3}{|c|}{ Sensitivity specification } & \multicolumn{3}{|c|}{ Level specification } \\
\hline Dependent variable & $\Delta D e p_{i t}^{U}$ & $\Delta D e p_{i t}^{U}$ & $\Delta D e p_{i t}^{U}$ & $\Delta D e p_{i t}^{U}$ & $\Delta D e p_{i t}^{U}$ & $\Delta D e p_{i t}^{U}$ \\
\hline & $(1)$ & $(2)$ & (3) & $(4)$ & (5) & $(6)$ \\
\hline$R O A_{i t-1} \times$ Asset Illiquidityit -1 & $\begin{array}{c}3.137 * * * \\
(3.261)\end{array}$ & $\begin{array}{c}3.321 * * * \\
(3.292)\end{array}$ & $\begin{array}{c}2.988^{* * * *} \\
(3.292)\end{array}$ & & & \\
\hline$R O A_{i t-1}$ & $\begin{array}{c}1.394 * * * \\
(5.099)\end{array}$ & $\begin{array}{c}1.432^{* * * *} \\
(5.040)\end{array}$ & $\begin{array}{c}1.367 * * * \\
(5.192)\end{array}$ & & & \\
\hline Asset Illiquidity $_{i t-1} \times I_{R O A<M e d}$ & & & & $\begin{array}{c}-4.747 * * * \\
(-3.514)\end{array}$ & $\begin{array}{c}-5.022 * * * \\
(-3.483)\end{array}$ & $\begin{array}{c}-4.682 * * * \\
(-3.543)\end{array}$ \\
\hline$I_{R O A<M e d}$ & & & & $\begin{array}{c}-1.105^{* * *} \\
(-3.539)\end{array}$ & $\begin{array}{c}-1.131 * * * \\
(-3.614)\end{array}$ & $\begin{array}{c}-1.082 * * * \\
(-3.493)\end{array}$ \\
\hline Asset Illiquidityit-1 & $\begin{array}{c}-5.715 \\
(-1.302)\end{array}$ & $\begin{array}{c}-6.098 \\
(-1.353)\end{array}$ & $\begin{array}{c}-5.491 \\
(-1.278)\end{array}$ & $\begin{array}{c}0.060 \\
(0.020)\end{array}$ & $\begin{array}{c}-0.035 \\
(-0.012)\end{array}$ & $\begin{array}{c}0.068 \\
(0.023)\end{array}$ \\
\hline$R O A_{i t-1} \times$ Persistence $_{i t-1}$ & $\begin{array}{l}0.606^{* *} \\
(2.341)\end{array}$ & & $\begin{array}{c}0.549 * * \\
(2.312)\end{array}$ & & & \\
\hline$R_{O A} A_{i t-1} \times$ Informativeness $_{i t-1}$ & & $\begin{array}{c}0.452^{* *} \\
(2.246)\end{array}$ & $\begin{array}{c}0.335^{* *} \\
(2.010)\end{array}$ & & & \\
\hline Persistence $_{i t-1} \times I_{R O A<M e d}$ & & & & $\begin{array}{c}-1.083 * * * \\
(-2.644)\end{array}$ & & $\begin{array}{c}-1.044 * * * \\
(-2.665)\end{array}$ \\
\hline Informativeness $_{i t-1} \times I_{R O A<M e d}$ & & & & & $\begin{array}{l}-0.437 * \\
(-1.950)\end{array}$ & $\begin{array}{l}-0.333^{*} \\
(-1.744)\end{array}$ \\
\hline Persistence $_{i t-1}$ & $\begin{array}{c}-1.399 * * * \\
(-2.750)\end{array}$ & & $\begin{array}{c}-1.312 * * * \\
(-2.763)\end{array}$ & $\begin{array}{c}-0.299 * * \\
(-2.058)\end{array}$ & & $\begin{array}{c}-0.288 * * \\
(-2.022)\end{array}$ \\
\hline Informativeness $_{i t-1}$ & & $\begin{array}{c}-0.921 * * \\
(-2.492)\end{array}$ & $\begin{array}{c}-0.738 * * \\
(-2.372)\end{array}$ & & $\begin{array}{c}-0.265 * * \\
(-2.283)\end{array}$ & $\begin{array}{l}-0.255^{* *} \\
(-2.255)\end{array}$ \\
\hline Controls & Y & $\mathrm{Y}$ & Y & Y & $\mathrm{Y}$ & $\mathrm{Y}$ \\
\hline Bank fixed effects & $\mathrm{Y}$ & $\mathrm{Y}$ & $\mathrm{Y}$ & $\mathrm{Y}$ & $\mathrm{Y}$ & $\mathrm{Y}$ \\
\hline Observations & 282,293 & 282,293 & 282,293 & 282,293 & 282,293 & 282,293 \\
\hline Adj. R-squared & 0.108 & 0.107 & 0.108 & 0.107 & 0.106 & 0.108 \\
\hline
\end{tabular}


Panel B: Covariate balance for the matched sample

\begin{tabular}{lccc}
\hline Subsample & $\begin{array}{c}\text { Bottom Tercile } \\
\text { of Asset Illiquidty }\end{array}$ & $\begin{array}{c}\text { Top Tercile } \\
\text { of Asset Illiquidity }\end{array}$ & \\
\hline Covariates & Mean & Mean & t-stat of Diff. \\
\hline Persistence & & & \\
Informativeness & 0.157 & 0.147 & -1.174 \\
C\&I_Loans & 0.211 & 0.206 & -0.784 \\
RealEstate_Loans & 0.160 & 0.161 & 0.264 \\
Wholesale_Funding & 0.688 & 0.690 & 0.414 \\
Capital_Ratio & 0.204 & 0.200 & -1.080 \\
\%Deposits & 0.100 & 0.100 & 0.374 \\
Ln(Size) & 0.826 & 0.827 & 0.523 \\
Std(ROE) & 12.655 & 12.634 & -0.594 \\
\%Uninsured & 4.959 & 4.898 & -0.443 \\
\hline
\end{tabular}


Panel C: Results on the matched sample

\begin{tabular}{|c|c|c|c|c|}
\hline \multirow[b]{2}{*}{ Dependent variable } & \multicolumn{2}{|c|}{ Sensitivity specification } & \multicolumn{2}{|c|}{ Level specification } \\
\hline & $\Delta D e p_{i t}^{U}$ & $\Delta D e p_{i t}^{U}$ & $\Delta D e p_{i t}^{U}$ & $\Delta D e p_{i t}^{U}$ \\
\hline & $(1)$ & (2) & (3) & (4) \\
\hline$R O A_{i t-1} \times I_{\text {High Asset Illiq }}$ & $\begin{array}{c}1.085^{* * *} \\
(3.461)\end{array}$ & $\begin{array}{c}0.969 * * * \\
(3.491)\end{array}$ & & \\
\hline$R O A_{i t-1}$ & $\begin{array}{c}0.841^{* * *} \\
(5.688)\end{array}$ & $\begin{array}{c}0.831 * * * \\
(5.796)\end{array}$ & & \\
\hline$I_{\text {High Asset Illiq }} \times I_{R O A<M e d}$ & & & $\begin{array}{c}-1.277 * * * \\
(-3.194)\end{array}$ & $\begin{array}{c}-1.265^{* * *} \\
(-3.231)\end{array}$ \\
\hline$I_{R O A<M e d}$ & & & $\begin{array}{c}-0.197 \\
(-0.638)\end{array}$ & $\begin{array}{c}-0.143 \\
(-0.455)\end{array}$ \\
\hline$I_{\text {High Asset Illiq }}$ & $\begin{array}{c}-1.423 \\
(-1.521)\end{array}$ & $\begin{array}{c}-1.294 \\
(-1.455)\end{array}$ & $\begin{array}{c}0.386 \\
(0.773)\end{array}$ & $\begin{array}{c}0.363 \\
(0.721)\end{array}$ \\
\hline$R O A_{i t-1} \times$ Persistence $_{i t-1}$ & & $\begin{array}{c}0.661 * * \\
(2.349)\end{array}$ & & \\
\hline$R O A_{i t-1} \times$ Informativeness $_{i t-1}$ & & $\begin{array}{c}0.360 * * * \\
(3.036)\end{array}$ & & \\
\hline Persistence $_{i t-1} \times I_{R O A<M e d}$ & & & & $\begin{array}{c}-0.987 * * \\
(-2.563)\end{array}$ \\
\hline Informativeness $_{i t-1} \times I_{R O A<M e d}$ & & & & $\begin{array}{c}-0.198 \\
(-1.292)\end{array}$ \\
\hline Persistence $_{i t-1}$ & & $\begin{array}{c}-1.457 * * * \\
(-2.656)\end{array}$ & & $\begin{array}{l}-0.321^{*} \\
(-1.776)\end{array}$ \\
\hline Informativeness $_{i t-1}$ & & $\begin{array}{c}-0.702 * * * \\
(-2.855)\end{array}$ & & $\begin{array}{c}-0.236 \\
(-1.515)\end{array}$ \\
\hline Controls & $\mathrm{Y}$ & $\mathrm{Y}$ & $\mathrm{Y}$ & $\mathrm{Y}$ \\
\hline Bank fixed effects & $\mathrm{Y}$ & $\mathrm{Y}$ & $\mathrm{Y}$ & $\mathrm{Y}$ \\
\hline Observations & 99,090 & 99,090 & 99,090 & 99,090 \\
\hline Adj. R-squared & 0.105 & 0.107 & 0.104 & 0.106 \\
\hline
\end{tabular}




\section{Table 7: Substitution between uninsured and insured deposits}

This table explores whether insured deposits help make up for the additional loss of uninsured deposits experienced by high liquidity mismatch banks. Panels A and B explore the effects on deposit flows using the sensitivity and level specifications. Panels C and D explore whether deposit rates can, at least partly, explain the substitution between uninsured and insured deposits. Controls include bank characteristics and the interaction terms of their demeaned values with either $R O A$ or $I_{R O A<M e d}$, and macro controls. Lagged deposit rates are also included as controls in Panels A and B. T-statistics, based on two-way clustered standard errors at the bank and year-quarter level, are presented in the parenthesis below. Statistical significance (two-sided) at the $10 \%, 5 \%$, and $1 \%$ level is denoted by $* * *$, and $* * *$, respectively.

Panel A: Results from sensitivity specifications

\begin{tabular}{|c|c|c|c|c|c|c|}
\hline \multirow{2}{*}{$\begin{array}{l}\text { MisMatch measure } \\
\text { Dependent variable }\end{array}$} & \multicolumn{3}{|c|}{ Asset Illiquidity } & \multicolumn{3}{|c|}{ \%Uninsured } \\
\hline & $\Delta D e p_{i t}^{U}$ & $\Delta D e p_{i t}^{I}$ & $\Delta D e p_{i t}^{\text {Total }}$ & $\Delta D e p_{i t}^{U}$ & $\Delta D e p_{i t}^{I}$ & $\Delta D e p_{i t}^{\text {Total }}$ \\
\hline & $(1)$ & $(2)$ & (3) & (4) & (5) & (6) \\
\hline$R O A_{i t-1} \times$ MisMatch $_{i t-1}$ & $\begin{array}{c}3.668 * * * \\
(3.179)\end{array}$ & $\begin{array}{l}-2.234^{*} \\
(-1.686)\end{array}$ & $\begin{array}{c}1.531 * * * \\
(3.372)\end{array}$ & $\begin{array}{c}0.041^{* * * *} \\
(3.800)\end{array}$ & $\begin{array}{c}-0.055^{* * *} \\
(-4.007)\end{array}$ & $\begin{array}{l}-0.010 * * \\
(-2.336)\end{array}$ \\
\hline$R O A_{i t-1}$ & $\begin{array}{c}1.499 * * * \\
(4.817)\end{array}$ & $\begin{array}{c}-0.330 \\
(-0.970)\end{array}$ & $\begin{array}{l}1.192 * * * \\
(12.513)\end{array}$ & $\begin{array}{c}1.386 * * * \\
(5.059)\end{array}$ & $\begin{array}{c}-0.081 \\
(-0.284)\end{array}$ & $\begin{array}{l}1.316^{* * *} \\
(13.682)\end{array}$ \\
\hline MisMatch $_{i t-1}$ & $\begin{array}{c}-6.417 \\
(-1.363)\end{array}$ & $\begin{array}{c}17.271^{* * *} \\
(3.376)\end{array}$ & $\begin{array}{c}9.869 * * * \\
(8.269)\end{array}$ & $\begin{array}{c}-0.287 * * * \\
(-3.594)\end{array}$ & $\begin{array}{c}0.336 * * * \\
(3.713)\end{array}$ & $\begin{array}{c}0.040 * * * \\
(2.640)\end{array}$ \\
\hline Controls & $\mathrm{Y}$ & $\mathrm{Y}$ & $\mathrm{Y}$ & $\mathrm{Y}$ & $\mathrm{Y}$ & $\mathrm{Y}$ \\
\hline Bank fixed effects & $\mathrm{Y}$ & $\mathrm{Y}$ & $\mathrm{Y}$ & $\mathrm{Y}$ & $\mathrm{Y}$ & $\mathrm{Y}$ \\
\hline Observations & 286,831 & 286,831 & 286,831 & 284,158 & 284,158 & 284,158 \\
\hline Adj. R-squared & 0.106 & 0.108 & 0.165 & 0.135 & 0.142 & 0.162 \\
\hline
\end{tabular}

Panel B: Results from level specifications

\begin{tabular}{|c|c|c|c|c|c|c|}
\hline \multirow{2}{*}{$\begin{array}{l}\text { MisMatch measure } \\
\text { Dependent variable }\end{array}$} & \multicolumn{3}{|c|}{ Asset Illiquidity } & \multicolumn{3}{|c|}{ \%Uninsured } \\
\hline & $\Delta D e p_{i t}^{U}$ & $\Delta D e p_{i t}^{I}$ & $\Delta D e p_{i t}^{\text {Total }}$ & $\Delta D e p_{i t}^{U}$ & $\Delta D e p_{i t}^{I}$ & $\Delta D e p_{i t}^{\text {Total }}$ \\
\hline & (1) & (2) & (3) & (4) & (5) & (6) \\
\hline$I_{R O A<M e d} \times$ MisMatch $_{i t-1}$ & $\begin{array}{c}-5.281 * * * \\
(-3.422)\end{array}$ & $\begin{array}{c}2.416 \\
(1.404)\end{array}$ & $\begin{array}{c}-2.895 * * * \\
(-4.357)\end{array}$ & $\begin{array}{c}-0.049 * * * \\
(-3.682)\end{array}$ & $\begin{array}{c}0.075^{* * *} \\
(4.470)\end{array}$ & $\begin{array}{c}0.023^{* * *} \\
(3.140)\end{array}$ \\
\hline$I_{R O A<M e d}$ & $\begin{array}{c}-1.167 * * * \\
(-3.571)\end{array}$ & $\begin{array}{c}-0.178 \\
(-0.527)\end{array}$ & $\begin{array}{c}-1.352^{* * *} \\
(-6.120)\end{array}$ & $\begin{array}{c}-0.843 * * * \\
(-2.668)\end{array}$ & $\begin{array}{c}-0.243 \\
(-0.797)\end{array}$ & $\begin{array}{c}-1.107 * * * \\
(-5.283)\end{array}$ \\
\hline MisMatch $_{\text {it-1 }}$ & $\begin{array}{c}0.189 \\
(0.063)\end{array}$ & $\begin{array}{c}13.697 * * * \\
(4.433)\end{array}$ & $\begin{array}{c}13.028 * * * \\
(11.287)\end{array}$ & $\begin{array}{c}-0.224 * * * \\
(-3.289)\end{array}$ & $\begin{array}{c}0.247^{* * *} \\
(3.374)\end{array}$ & $\begin{array}{c}0.018 \\
(1.071)\end{array}$ \\
\hline Controls & $\mathrm{Y}$ & $\mathrm{Y}$ & $\mathrm{Y}$ & $\mathrm{Y}$ & $\mathrm{Y}$ & $\mathrm{Y}$ \\
\hline Bank fixed effects & $\mathrm{Y}$ & $\mathrm{Y}$ & $\mathrm{Y}$ & $\mathrm{Y}$ & $\mathrm{Y}$ & $\mathrm{Y}$ \\
\hline Observations & 286,831 & 286,831 & 286,831 & 284,158 & 284,158 & 284,158 \\
\hline Adj. R-squared & 0.106 & 0.107 & 0.165 & 0.134 & 0.139 & 0.162 \\
\hline
\end{tabular}


Panel C: Deposit rate results from sensitivity specifications

\begin{tabular}{|c|c|c|c|c|}
\hline \multirow{2}{*}{$\begin{array}{l}\text { MisMatch measure } \\
\text { Dependent variable }\end{array}$} & \multicolumn{2}{|c|}{ Asset Illiquidity } & \multicolumn{2}{|c|}{ \%Uninsured } \\
\hline & $\log \left(\right.$ RateCore $\left._{\text {it }}\right)$ & $\log \left(\right.$ RateLT $\left._{\text {it }}\right)$ & $\log \left(\right.$ RateCore $\left._{i t}\right)$ & $\log \left(\right.$ RateLT $\left._{\text {it }}\right)$ \\
\hline & $(1)$ & (2) & (3) & (4) \\
\hline$R O A_{i t-1} \times$ MisMatch $_{i t-1}$ & $\begin{array}{c}-0.311^{* * *} \\
(-7.516)\end{array}$ & $\begin{array}{c}-0.165^{* * *} \\
(-4.985)\end{array}$ & $\begin{array}{c}-0.002 * * * \\
(-6.355)\end{array}$ & $\begin{array}{c}-0.001 * * * \\
(-4.508)\end{array}$ \\
\hline$R O A_{i t-1}$ & $\begin{array}{c}-0.007 \\
(-0.528)\end{array}$ & $\begin{array}{l}-0.005 \\
(-0.524)\end{array}$ & $\begin{array}{c}-0.004 \\
(-0.272)\end{array}$ & $\begin{array}{l}-0.000 \\
(-0.042)\end{array}$ \\
\hline MisMatch $_{i t-1}$ & $\begin{array}{c}1.142 * * * \\
(6.449)\end{array}$ & $\begin{array}{c}0.812 * * * \\
(5.681)\end{array}$ & $\begin{array}{c}0.012 * * * \\
(4.567)\end{array}$ & $\begin{array}{c}0.010 * * * \\
(4.251)\end{array}$ \\
\hline Controls & $\mathrm{Y}$ & $\mathrm{Y}$ & $\mathrm{Y}$ & $\mathrm{Y}$ \\
\hline Bank fixed effects & $\mathrm{Y}$ & $\mathrm{Y}$ & $\mathrm{Y}$ & $\mathrm{Y}$ \\
\hline Observations & 284,675 & 284,478 & 281,991 & 281,804 \\
\hline Adj. R-squared & 0.783 & 0.706 & 0.786 & 0.710 \\
\hline
\end{tabular}

Panel D: Deposit rate results from level specifications

\begin{tabular}{lcccc}
\hline MisMatch measure & \multicolumn{2}{c}{ Asset Illiquidity } & \multicolumn{2}{c}{ \%Uninsured } \\
\hline Dependent variable & $\log \left(\right.$ RateCore $\left._{\text {it }}\right)$ & $\log \left(\right.$ RateLT $\left._{\text {it }}\right)$ & $\log \left(\right.$ RateCore $\left._{\text {it }}\right)$ & $\log \left(\right.$ RateLT $\left._{\text {it }}\right)$ \\
\hline$I_{\text {ROA<Med }} \times$ MisMatch $_{\text {it- } 1}$ & $0.382^{* * *}$ & $(2)$ & $(3)$ & $(4)$ \\
& $(5.812)$ & $(4.014)$ & $(4.941)$ & $(2.126)$ \\
$I_{\text {ROA<Med }}$ & $0.059^{* * *}$ & $0.037^{* * *}$ & $0.057^{* * *}$ & $0.034^{* * *}$ \\
& $(3.626)$ & $(2.965)$ & $(3.788)$ & $(2.952)$ \\
MisMatch & & $0.535^{* * *}$ & $0.009^{* * *}$ & $0.008^{* * *}$ \\
& $0.622^{* * *}$ & $0.5 * *$ & $(3.833)$ \\
Controls $_{\text {Bank fixed effects }}$ & $(4.837)$ & $(5.189)$ & $(3.587)$ & \\
Observations & & & & $\mathrm{Y}$ \\
Adj. R-squared & $\mathrm{Y}$ & $\mathrm{Y}$ & $\mathrm{Y}$ & $\mathrm{Y}$ \\
\hline
\end{tabular}




\section{Table 8: Systematic vs idiosyncratic performance shocks}

This table explores if the effect of liquidity mismatch on uninsured depositors depends on whether the performance shock is systematic or idiosyncratic. Panel A presents the results from the sensitivity specification where ROA_Sys $s_{t}$ is the average ROA for all banks in a given quarter and ROA_Idio ${ }_{i t}$ is the difference between $R O A_{i t}$ and ROA_Sys. Panel B presents the results for level specifications where $I_{R O A<M e d}$ is the indicator variable for whether the bank has below sample median $R O A$ performance, $I_{\text {Poorsys \& ROA }<\text { Med }}=I_{R O A<M e d}$ * $I\left(R_{0} A_{-}\right.$Sys $_{t}<$ Cutof $\left._{\text {sys }}\right)$ where Cutoff $f_{\text {sys }}$ is equal to the bottom 1/3, 1/4, and $1 / 5$ values of sample ROA_Sys in columns (1) and (4), in columns (2) and (5), and in columns (3) and (6), respectively. Similarly,

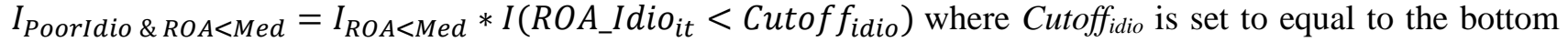
1/3, 1/4, and 1/5 of sample ROA_Idio in columns (1) and (4), in columns (2) and (5), and in columns (3) and (6), respectively. Controls include bank characteristics and the interaction terms of their demeaned values with either ROA_Sys and ROA_Idio in Panel A or with the performance indicator variables in Panel B, lagged deposit rates, and macro controls. T-statistics, based on two-way clustered standard errors at the bank and year-quarter level, are presented in the parenthesis below. Statistical significance (two-sided) at the $10 \%$, 5\%, and 1\% level is denoted by $*, * *$, and $* * *$, respectively.

Panel A: Results from the sensitivity specification

\begin{tabular}{|c|c|c|}
\hline MisMatch measure & Asset Illiquidity & \%Uninsured \\
\hline Dependent variable & $\Delta D e p_{i t}^{U}$ & $\Delta D e p_{i t}^{U}$ \\
\hline & (1) & $(2)$ \\
\hline ROA_Sys ${ }_{t-1} \times$ MisMatch $_{i t-1}$ & $\begin{array}{c}11.682^{* *} \\
(2.189)\end{array}$ & $\begin{array}{c}0.160 * * * \\
(2.638)\end{array}$ \\
\hline ROA_Idio ${ }_{i t-1} \times$ MisMatch $_{i t-1}$ & $\begin{array}{c}1.581^{* * *} \\
(3.078)\end{array}$ & $\begin{array}{c}0.020 * * * \\
(4.122)\end{array}$ \\
\hline ROA_Sys ${ }_{t-1}$ & $\begin{array}{c}6.753^{* * *} \\
(2.732)\end{array}$ & $\begin{array}{c}5.436^{* *} \\
(2.172)\end{array}$ \\
\hline ROA_Idio $_{i t-1}$ & $\begin{array}{c}0.884^{* * *} \\
(8.087)\end{array}$ & $\begin{array}{c}0.909 * * * \\
(9.357)\end{array}$ \\
\hline MisMatch $_{i t-1}$ & $\begin{array}{l}-13.042 * \\
(-1.703)\end{array}$ & $\begin{array}{c}-0.373 * * * \\
(-3.421)\end{array}$ \\
\hline Controls & $\mathrm{Y}$ & $\mathrm{Y}$ \\
\hline Bank fixed effects & $\mathrm{Y}$ & $\mathrm{Y}$ \\
\hline Observations & 286,831 & 284,158 \\
\hline Adj. R-squared & 0.128 & 0.150 \\
\hline
\end{tabular}


Panel B: Results from the level specification

\begin{tabular}{|c|c|c|c|c|c|c|}
\hline MisMatch measure & \multicolumn{3}{|c|}{ Asset Illiquidity } & \multicolumn{3}{|c|}{ \%Uninsured } \\
\hline Poor shock cut-off & $\begin{array}{c}\text { Bottom } \\
1 / 3^{\text {rd }} \\
\end{array}$ & $\begin{array}{c}\text { Bottom } \\
1 / 4^{\text {th }}\end{array}$ & $\begin{array}{c}\text { Bottom } \\
1 / 5^{\text {th }}\end{array}$ & $\begin{array}{c}\text { Bottom } \\
1 / 3^{\text {rd }}\end{array}$ & $\begin{array}{c}\text { Bottom } \\
1 / 4^{\text {th }}\end{array}$ & $\begin{array}{c}\text { Bottom } \\
1 / 5^{\text {th }}\end{array}$ \\
\hline Dependent variable & $\Delta D e p_{i t}^{U}$ & $\Delta D e p_{i t}^{U}$ & $\Delta D e p_{i t}^{U}$ & $\Delta D e p_{i t}^{U}$ & $\Delta D e p_{i t}^{U}$ & $\Delta D e p_{i t}^{U}$ \\
\hline & (1) & $(2)$ & (3) & (4) & (5) & (6) \\
\hline MisMatch $_{\text {it- } 1} \times I_{\text {PoorSys \& ROA }<\text { Med }}$ & $\begin{array}{c}-10.709 * * \\
(-2.621)\end{array}$ & $\begin{array}{l}-9.641^{*} \\
(-1.966)\end{array}$ & $\begin{array}{l}-9.180 * \\
(-1.746)\end{array}$ & $\begin{array}{c}-0.130 * * * \\
(-2.782)\end{array}$ & $\begin{array}{c}-0.141^{* *} \\
(-2.515)\end{array}$ & $\begin{array}{c}-0.151 * * * \\
(-2.723)\end{array}$ \\
\hline MisMatch $_{\text {it- } 1} \times I_{\text {PoorIdio } \& \text { ROA }<\text { Med }}$ & $\begin{array}{c}-2.181 * * * \\
(-2.917)\end{array}$ & $\begin{array}{c}-2.485 * * * \\
(-3.131)\end{array}$ & $\begin{array}{c}-2.764^{* * *} \\
(-3.308)\end{array}$ & $\begin{array}{c}-0.022 * * * \\
(-3.382)\end{array}$ & $\begin{array}{c}-0.025 * * * \\
(-3.419)\end{array}$ & $\begin{array}{c}-0.031 * * * \\
(-3.833)\end{array}$ \\
\hline MisMatch $_{i t-1} \times I_{R O A<M e d}$ & $\begin{array}{c}-0.453 \\
(-0.526)\end{array}$ & $\begin{array}{c}-1.768 * * \\
(-2.621)\end{array}$ & $\begin{array}{c}-2.084^{* * *} \\
(-3.208)\end{array}$ & $\begin{array}{c}0.010 \\
(0.708)\end{array}$ & $\begin{array}{c}0.001 \\
(0.082)\end{array}$ & $\begin{array}{c}0.000 \\
(0.006)\end{array}$ \\
\hline$I_{R O A<M e d}$ & $\begin{array}{c}0.088 \\
(0.162)\end{array}$ & $\begin{array}{c}0.009 \\
(0.016)\end{array}$ & $\begin{array}{c}0.036 \\
(0.059)\end{array}$ & $\begin{array}{c}0.238 \\
(0.445)\end{array}$ & $\begin{array}{c}0.052 \\
(0.096)\end{array}$ & $\begin{array}{c}-0.015 \\
(-0.027)\end{array}$ \\
\hline$I_{\text {PoorSys } \& \text { ROA }<\text { Med }}$ & $\begin{array}{l}-2.941^{* *} \\
(-2.323)\end{array}$ & $\begin{array}{l}-3.249 * * \\
(-1.989)\end{array}$ & $\begin{array}{l}-3.729 * \\
(-1.910)\end{array}$ & $\begin{array}{l}-2.445^{* *} \\
(-2.191)\end{array}$ & $\begin{array}{c}-2.318 \\
(-1.647)\end{array}$ & $\begin{array}{c}-2.214 \\
(-1.338)\end{array}$ \\
\hline$I_{\text {PoorIdio \& } R O A<M e d}$ & $\begin{array}{c}0.066 \\
(0.289)\end{array}$ & $\begin{array}{c}-0.080 \\
(-0.344)\end{array}$ & $\begin{array}{c}-0.196 \\
(-0.618)\end{array}$ & $\begin{array}{c}-0.064 \\
(-0.279)\end{array}$ & $\begin{array}{c}-0.092 \\
(-0.397)\end{array}$ & $\begin{array}{c}-0.136 \\
(-0.449)\end{array}$ \\
\hline MisMatch $_{i t-1}$ & $\begin{array}{c}0.472 \\
(0.165)\end{array}$ & $\begin{array}{c}0.703 \\
(0.255)\end{array}$ & $\begin{array}{c}1.090 \\
(0.421)\end{array}$ & $\begin{array}{c}-0.211 * * * \\
(-3.375)\end{array}$ & $\begin{array}{c}-0.210 * * * \\
(-3.454)\end{array}$ & $\begin{array}{c}-0.207 * * * \\
(-3.519)\end{array}$ \\
\hline Controls & $\mathrm{Y}$ & $\mathrm{Y}$ & $\mathrm{Y}$ & $\mathrm{Y}$ & $\mathrm{Y}$ & $\mathrm{Y}$ \\
\hline Bank fixed effects & $\mathrm{Y}$ & $\mathrm{Y}$ & $\mathrm{Y}$ & $\mathrm{Y}$ & $\mathrm{Y}$ & $\mathrm{Y}$ \\
\hline Observations & 286,831 & 286,831 & 286,831 & 284,158 & 284,158 & 284,158 \\
\hline Adj. R-squared & 0.116 & 0.116 & 0.117 & 0.143 & 0.142 & 0.142 \\
\hline
\end{tabular}


Table 9: Liquidity mismatch and the 2008 Financial Crisis

This table explores how the effects of the 2008 Financial Crisis vary with the degree of a bank's pre-crisis liquidity mismatch. Panels A and B present results with Asset Illiquidity and \%Uninsured as the mismatch measure. Crisis is an indicator variable for the crisis period of 2007Q3 to 2009Q2. MisMatch and all the bank characteristics we control for are measured as of the quarter just before the onset of the crisis. The estimation sample contains data for up to 5 years prior to the crisis period and ends with the crisis period. Controls include the bank characteristics (measured at the quarter prior to the crisis) and their interaction terms with Crisis. T-statistics, based on two-way clustered standard errors at the bank and year-quarter level, are presented in the parenthesis below. Statistical significance (two-sided) at the $10 \%, 5 \%$, and $1 \%$ level is denoted by *, **, and ***, respectively.

Panel A: Results for Asset Illiquidity

\begin{tabular}{|c|c|c|c|c|c|c|c|}
\hline Dependent variable & $\Delta D e p_{i t}^{U}$ & $\Delta D e p_{i t}^{I}$ & $\Delta D e p_{i t}^{\text {Total }}$ & $\frac{\log \left(\text { RateCore }_{i t}\right)}{(4)}$ & $\log \left(\right.$ RateLT $\left._{\mathrm{it}}\right)$ & $\Delta \operatorname{Loan}_{i t}$ & $\Delta$ Commit $_{i t}$ \\
\hline Crisis $_{t} \times$ MisMatch $_{i}$ & $\begin{array}{c}-10.406 * * * \\
(-6.906)\end{array}$ & $\begin{array}{c}-0.736 \\
(-0.424)\end{array}$ & $\begin{array}{c}-11.570 * * * \\
(-6.151)\end{array}$ & $\begin{array}{c}0.201^{* * *} \\
(4.195)\end{array}$ & $\begin{array}{c}0.069 * * \\
(2.744)\end{array}$ & $\begin{array}{c}-20.776^{* * *} \\
(-8.993)\end{array}$ & $\begin{array}{c}-8.766 * * * \\
(-8.298)\end{array}$ \\
\hline Controls & Yes & Yes & Yes & Yes & Yes & Yes & Yes \\
\hline Bank fixed effects & Yes & Yes & Yes & Yes & Yes & Yes & Yes \\
\hline Quarter fixed effects & Yes & Yes & Yes & Yes & Yes & Yes & Yes \\
\hline Observations & 89,011 & 89,011 & 89,011 & 88,795 & 88,844 & 89,011 & 89,011 \\
\hline Adj. R-squared & 0.294 & 0.336 & 0.152 & 0.827 & 0.716 & 0.271 & 0.102 \\
\hline
\end{tabular}

Panel B: Results for \%Uninsured

\begin{tabular}{|c|c|c|c|c|c|c|c|}
\hline Dependent variable & $\Delta D e p_{i t}^{U}$ & $\Delta D e p_{i t}^{I}$ & $\Delta D e p_{i t}^{\text {Total }}$ & $\log \left(\right.$ RateCore $\left._{i t}\right)$ & $\log \left(\right.$ RateLT $\left._{\mathrm{it}}\right)$ & $\Delta$ Loan $_{i t}$ & $\Delta$ Commit $_{i t}$ \\
\hline & $(1)$ & $(2)$ & (3) & $(4)$ & (5) & $(6)$ & $(7)$ \\
\hline Crisis $_{t} \times$ MisMatch $_{i}$ & $\begin{array}{c}-0.118 * * * \\
(-4.591)\end{array}$ & $\begin{array}{l}0.051 * \\
(2.045)\end{array}$ & $\begin{array}{c}-0.074 * * * \\
(-3.489)\end{array}$ & $\begin{array}{c}-0.001 \\
(-0.769)\end{array}$ & $\begin{array}{c}0.000 \\
(0.242)\end{array}$ & $\begin{array}{c}-0.081 * * * \\
(-4.467)\end{array}$ & $\begin{array}{c}-0.073 * * * \\
(-9.005)\end{array}$ \\
\hline Controls & Yes & Yes & Yes & Yes & Yes & Yes & Yes \\
\hline Bank fixed effects & Yes & Yes & Yes & Yes & Yes & Yes & Yes \\
\hline Quarter fixed effects & Yes & Yes & Yes & Yes & Yes & Yes & Yes \\
\hline Observations & 89,011 & 89,011 & 89,011 & 88,795 & 88,844 & 89,011 & 89,011 \\
\hline Adj. R-squared & 0.294 & 0.336 & 0.152 & 0.827 & 0.716 & 0.271 & 0.102 \\
\hline
\end{tabular}




\section{Appendix: Variable definitions}

\begin{tabular}{|c|c|}
\hline Variables & Definitions \\
\hline$R O A_{i, t-1}$ & $\begin{array}{l}\text { Annualized ROA (in \%) in quarter t-1, calculated as net income (RIAD4300, adjust year-to- } \\
\text { date reporting to within quarter) divided by beginning assets. }\end{array}$ \\
\hline$I_{R O A<M e d}$ & $\begin{array}{l}\text { An indicator variable that equals } 1 \text { for observations where } R O A_{i, t-1} \text { is below the sample median } \\
\text { level of } R O A \text {, and } 0 \text { otherwise. }\end{array}$ \\
\hline Asset Illiquidity & $\begin{array}{l}\text { The measure of liquidity creation per unit of gross total assets, by Berger and Bouwman } \\
\text { (2009) and downloaded from https://sites.google.com/a/tamu.edu/bouwman/data. } \\
\text { Step 1: Classify all bank activities on a bank’s asset side (including off-balance-sheet } \\
\text { activity) as liquid, semi-liquid, or illiquid based on product category. } \\
\text { Step 2: Assign weights to the activities classified in Step } 1 \text {. Illiquid assets, get 1/2, semi-liquid } \\
\text { assets get } 0 \text { and liquid assets get }-1 / 2 \text {. } \\
\text { Step 3: Combine bank asset activities as classified in Step } 1 \text { and as weighted in Step } 2 \text { to } \\
\text { construct the asset illiquidity measure. }\end{array}$ \\
\hline \%Uninsured & $\begin{array}{l}\text { The fraction of deposits that are uninsured (shown in percentage term) averaged over the } \\
\text { preceding } 12 \text { quarters with a minimum of six observations available. }\end{array}$ \\
\hline$\Delta D e p_{i t}^{U}$ & $\begin{array}{l}\text { Annualized growth rate in uninsured deposits as a percentage of lagged assets (in \%) in } \\
\text { quarter } t \text { and } t+1 \text {. Uninsured deposit is calculated as total deposits (RCFD2200) - insured } \\
\text { deposits. }\end{array}$ \\
\hline Ln(Assets) & Log of total assets (RCFD2170). \\
\hline C\&I Loan $_{i, t-1}$ & Commercial and industrial loan (RCFD1766), scaled by lagged total assets. \\
\hline RealEstate_Loan & Loans secured by real estate (RCFD1410) scaled by total loans (RCFD1400). \\
\hline Wholesale_Funding & $\begin{array}{l}\text { Wholesale funds are the sum of following: large-time deposits (RCON2604), deposits booked } \\
\text { in foreign offices (RCFN2200), subordinated debt and debentures (RCFD3200), gross federal } \\
\text { funds purchased and repos [RCFD2800, or (RCONB993+RCFDB995 from 2002q1)], other } \\
\text { borrowed money (RCFD3190). Scaled by total assets. }\end{array}$ \\
\hline Capital_Ratio & Total equity (RCFD3210) divided by total assets (RCFD2170). \\
\hline \%Deposits & Ratio of total deposits to assets \\
\hline $\operatorname{Std}(R O E)_{i, t-1}$ & Standard deviation of ROE measured over 12 rolling quarters (from Quarter $t-12$ to $t-1$ ). \\
\hline Core deposit Rate $e_{i, t}$ & $\begin{array}{l}\text { Core deposits include transaction, saving, and small time deposits, and core deposit rate is the } \\
\text { average interest rate paid on the three. }\end{array}$ \\
\hline $\begin{array}{l}\text { Large Time Deposit } \\
\text { Rate }_{i, t}\end{array}$ & $\begin{array}{l}\text { Annualized average interest rate (in \%) over the two quarters } t, t+1 \text { on savings deposits: } \\
\text { (larget timedeposit interest expense in } Q \operatorname{tr} t \text { and } t+1) / \\
\text { (Avg. large time deposit balance in Qtr t and } t+1)) * 400 \%) \text {. }\end{array}$ \\
\hline Persistence $_{i t-1}$ & $\begin{array}{l}\text { The slope coefficient } \beta_{1} \text { in } R O E_{t}=\alpha_{0}+\beta_{1} R O E_{i t-1}+\epsilon \text {, estimated for each bank-quarter } \\
\text { using the bank's observations over the previous } 12 \text { quarters. }\end{array}$ \\
\hline Informativeness & $\begin{array}{l}\text { The adjusted R-squared from the following regression } \\
\text { WriteOf } f_{t}=\alpha_{0}+\sum_{k=1}^{2}\left(\delta_{k} E B L L P_{t-k}+\beta_{k} L L P_{t-k}+\gamma_{k} \Delta N P L_{t-k}\right)+\rho \text { Capital }_{t-1}+\varepsilon_{t} \text {, } \\
\text { estimated for each bank-quarter using the bank's observations over the previous } 12 \text { quarters. }\end{array}$ \\
\hline$\Delta D e p_{i t}^{I}$ & $\begin{array}{l}\text { Annualized growth rate in insured deposits as a percentage of lagged assets in quarter } t \text { and } \\
t+1 \text {. (in \%): (Insured Deposits } \\
\left.\text { Int }+1+\text { Insured Deposits }_{i, t-1}\right) / \text { Asset }_{i, t-1} * 200 \% \text {. } \\
\text { Insured deposits are accounts of } \$ 100,000 \text { or less. After 2006Q2, it includes retirement } \\
\text { accounts of } \$ 250,000 \text { or less. From } 2009 \mathrm{Q} 3 \text {, reporting thresholds on non-retirement deposits } \\
\text { increased from } \$ 100,000 \text { to } \$ 250,000 \text {. } \\
\text { Insured deposits: RCON2702 (before 2006Q2); RCONF049 + RCONF045 (from 2006Q2). }\end{array}$ \\
\hline$\Delta$ Dep $p_{i t}^{T o t a l}$ & Sum of $\Delta D e p_{i t}^{I}$ and $\Delta D e p_{i t}^{U}$ \\
\hline
\end{tabular}




\section{Online Appendix}

for

\section{Liquidity Transformation and Fragility in the US Banking Sector (Not intended for publication)}

Qi Chen
Duke University, 100 Fuqua Drive, Durham, NC 27708, United States

Phone: 919-660-7753 / Email: qc2@duke.edu

Itay Goldstein ${ }^{\dagger}$

Wharton School, 3620 Locust Walk, Philadelphia, PA 19104, United States

Phone: 215-746-0499 / Email: itayg@wharton.upenn.edu

Zeqiong Huang

Yale University, 165 Whitney Avenue, New Haven, CT 06511, United States

Phone: (203)436-9426 / Email: zeqiong.huang@yale.edu

Rahul Vashishtha

Duke University, 100 Fuqua Drive, Durham, NC 27708, United States

Phone: 919-660-7755 / Email: rahul.vashishtha@duke.edu

This Draft: October 2022 
Figure A1: Changes around the Financial Crisis of 2008

This figure plots the quarterly sample average values of LMIRisk from Bai et al. (2018) and of uninsured deposit flows around the 2008 Financial Crisis period.

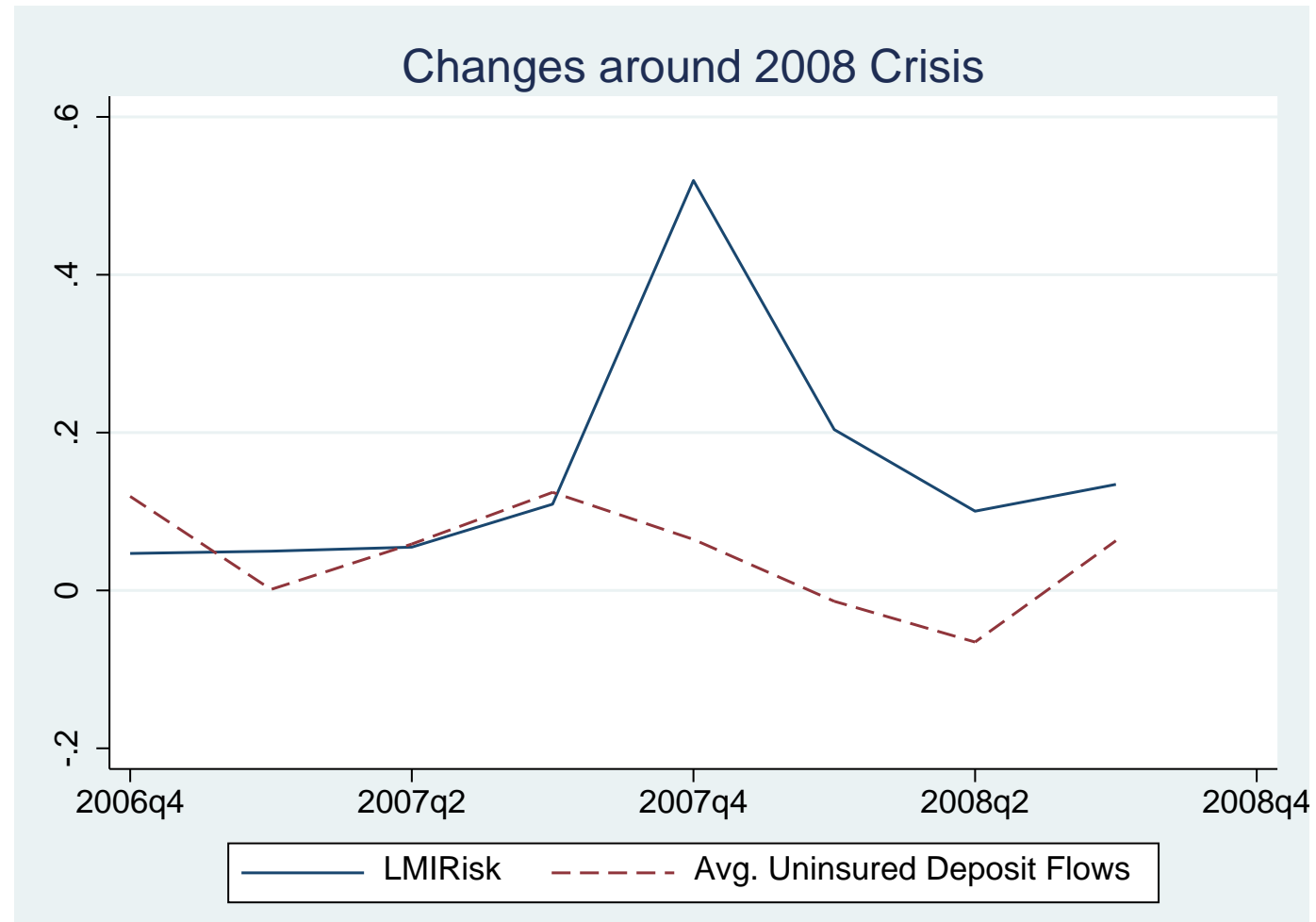




\section{Table A1: Main results in subsamples by bank asset size}

This table explores whether the effect of liquidity mismatch on deposit flows differs by bank asset size for the sensitivity specification (Panel A) and the levels specification (Panel B). Small banks are defined as those with total assets below 500 million, large banks have assets above 3 billion, and medium banks have assets between 500 million and 3 billion (measured in 2000 real dollars). Controls include time-varying bank characteristics and the interaction terms of their sample demeaned values with either $R O A$ or $I_{R O A<M e d}$, lagged deposit rates, and macro controls. T-statistics, reported in parentheses, are based on standard error estimates two-way clustered at the bank and year-quarter level. Statistical significance (two-sided) at the $10 \%, 5 \%$, and $1 \%$ level is denoted by *, **, and ***, respectively.

Panel A: Sensitivity specification

\begin{tabular}{|c|c|c|c|c|c|c|}
\hline \multirow[b]{2}{*}{ Dependent variable } & \multicolumn{2}{|c|}{$\begin{array}{l}\text { Small banks: } \\
\text { Assets } \\
\in(0.1,0.5 \text { billion })\end{array}$} & \multicolumn{2}{|c|}{$\begin{array}{l}\text { Medium banks: } \\
\text { Assets } \\
\in(0.5,3 \text { billion })\end{array}$} & \multicolumn{2}{|c|}{$\begin{array}{c}\text { Large banks: } \\
\text { Assets }>3 \text { billion }\end{array}$} \\
\hline & $\Delta D e p_{i t}^{U}$ & $\Delta D e p_{i t}^{U}$ & $\Delta D e p_{i t}^{U}$ & $\Delta D e p_{i t}^{U}$ & $\Delta D e p_{i t}^{U}$ & $\Delta D e p_{i t}^{U}$ \\
\hline & $(1)$ & (2) & (3) & (4) & (5) & (6) \\
\hline$R O A_{i t-1} \times$ Asset Illiquidity $_{i t-1}$ & $\begin{array}{c}3.237 * * * \\
(2.841)\end{array}$ & & $\begin{array}{c}3.804^{* * *} \\
(2.891)\end{array}$ & & $\begin{array}{l}4.778^{* *} \\
(2.096)\end{array}$ & \\
\hline$R O A_{i t-1} \times \%$ Uninsured $_{i t-1}$ & & $\begin{array}{c}0.041^{* * *} \\
(3.332)\end{array}$ & & $\begin{array}{c}0.037 * * * \\
(3.612)\end{array}$ & & $\begin{array}{c}0.019 * * \\
(2.222)\end{array}$ \\
\hline$R O A_{i t-1}$ & $\begin{array}{c}1.481 * * * \\
(4.438)\end{array}$ & $\begin{array}{c}1.407 * * * \\
(4.585)\end{array}$ & $\begin{array}{c}1.063 * * * \\
(3.292)\end{array}$ & $\begin{array}{c}1.092^{* * *} \\
(3.193)\end{array}$ & $\begin{array}{l}1.393^{* *} \\
(2.134)\end{array}$ & $\begin{array}{c}1.961^{* * *} \\
(2.703)\end{array}$ \\
\hline Asset Illiquidity it-1 & $\begin{array}{c}-5.496 \\
(-1.153)\end{array}$ & & $\begin{array}{c}-7.831 \\
(-1.427)\end{array}$ & & $\begin{array}{l}-7.783 * \\
(-1.822)\end{array}$ & \\
\hline \%Uninsured & & $\begin{array}{c}-0.310 * * * \\
(-3.458)\end{array}$ & & $\begin{array}{c}-0.288 * * * \\
(-3.861)\end{array}$ & & $\begin{array}{c}-0.179 * * * \\
(-5.991)\end{array}$ \\
\hline Controls & $\mathrm{Y}$ & $\mathrm{Y}$ & $\mathrm{Y}$ & $\mathrm{Y}$ & $\mathrm{Y}$ & $\mathrm{Y}$ \\
\hline Bank fixed effects & $\mathrm{Y}$ & $\mathrm{Y}$ & $\mathrm{Y}$ & $\mathrm{Y}$ & $\mathrm{Y}$ & $\mathrm{Y}$ \\
\hline Observations & 231,860 & 229,753 & 43,169 & 42,757 & 11,678 & 11,531 \\
\hline Adj. R-squared & 0.106 & 0.137 & 0.161 & 0.187 & 0.117 & 0.134 \\
\hline
\end{tabular}


Panel B: Level specification

\begin{tabular}{|c|c|c|c|c|c|c|}
\hline \multirow[b]{2}{*}{ Dependent variable } & \multicolumn{2}{|c|}{$\begin{array}{l}\text { Small banks: } \\
\text { Assets } \\
\in(0.1,0.5 \text { billion })\end{array}$} & \multicolumn{2}{|c|}{$\begin{array}{l}\text { Medium banks: } \\
\text { Assets } \\
\in(0.5,3 \text { billion })\end{array}$} & \multicolumn{2}{|c|}{$\begin{array}{c}\text { Large banks: } \\
\text { Assets }>3 \text { billion }\end{array}$} \\
\hline & $\Delta D e p_{i t}^{U}$ & $\Delta D e p_{i t}^{U}$ & $\Delta D e p_{i t}^{U}$ & $\Delta D e p_{i t}^{U}$ & $\Delta D e p_{i t}^{U}$ & $\Delta D e p_{i t}^{U}$ \\
\hline & (1) & (2) & (3) & (4) & (5) & (6) \\
\hline$I_{R O A<M e d} \times$ Asset Illiquidity $_{i t-1}$ & $\begin{array}{c}-4.777 * * * \\
(-3.258)\end{array}$ & & $\begin{array}{c}-7.725 * * * \\
(-3.620)\end{array}$ & & $\begin{array}{c}-6.868 * * \\
(-2.184)\end{array}$ & \\
\hline$I_{R O A<M e d} \times \%$ Uninsured ${ }_{i t-1}$ & & $\begin{array}{c}-0.047 * * * \\
(-3.285)\end{array}$ & & $\begin{array}{c}-0.056 * * * \\
(-3.206)\end{array}$ & & $\begin{array}{c}-0.007 \\
(-0.360)\end{array}$ \\
\hline$I_{R O A<M e d}$ & $\begin{array}{c}-1.149 * * * \\
(-3.360)\end{array}$ & $\begin{array}{c}-1.016 * * * \\
(-2.891)\end{array}$ & $\begin{array}{c}0.340 \\
(0.556)\end{array}$ & $\begin{array}{c}0.778 \\
(1.326)\end{array}$ & $\begin{array}{c}-3.526 * * \\
(-2.306)\end{array}$ & $\begin{array}{l}-3.725^{* *} \\
(-2.350)\end{array}$ \\
\hline Asset Illiquidity it-1 & $\begin{array}{c}0.484 \\
(0.156)\end{array}$ & & $\begin{array}{c}-0.294 \\
(-0.074)\end{array}$ & & $\begin{array}{c}0.254 \\
(0.085)\end{array}$ & \\
\hline${ }_{\text {oUninsured }}{ }_{i t-1}$ & & $\begin{array}{c}-0.249 * * * \\
(-3.228)\end{array}$ & & $\begin{array}{c}-0.230 * * * \\
(-3.494)\end{array}$ & & $\begin{array}{c}-0.151 * * * \\
(-5.366)\end{array}$ \\
\hline Controls & $\mathrm{Y}$ & $\mathrm{Y}$ & $\mathrm{Y}$ & $\mathrm{Y}$ & $\mathrm{Y}$ & $\mathrm{Y}$ \\
\hline Bank fixed effects & $\mathrm{Y}$ & $\mathrm{Y}$ & $\mathrm{Y}$ & $\mathrm{Y}$ & $\mathrm{Y}$ & $\mathrm{Y}$ \\
\hline Observations & 231,860 & 229,753 & 43,169 & 42,757 & 11,678 & 11,531 \\
\hline Adj. R-squared & 0.106 & 0.136 & 0.160 & 0.185 & 0.117 & 0.134 \\
\hline
\end{tabular}




\section{Table A2. Robustness to alternative scaling of dependent variable}

This table presents evidence on the robustness of our results when we calculate the dependent variable as changes in uninsured deposit balances scaled by the beginning balance of uninsured deposits. Columns (1) to (4) present the results for both the sensitivity and level specifications for the whole sample and columns (5) to (8) present the results for the matched samples. Controls include time-varying bank characteristics and the interactive terms of their sample demeaned values with either $R O A$ or $I_{R O A<M e d}$, lagged deposit rates, and macro controls. T-statistics, based on two-way clustered standard errors at the bank and year-quarter level, are presented in the parenthesis below. Statistical significance (two-sided) at the $10 \%, 5 \%$, and $1 \%$ level is denoted by $*, * *$, and $* * *$, respectively.

\begin{tabular}{|c|c|c|c|c|c|c|c|c|c|}
\hline \multicolumn{6}{|c|}{ Whole sample analysis } & \multicolumn{4}{|c|}{ Matched sample analysis } \\
\hline $\begin{array}{l}\text { Mismatch } \\
\text { measure }\end{array}$ & \multicolumn{2}{|c|}{ Asset Illiquidity } & \multicolumn{2}{|c|}{ \%Uninsured } & & \multicolumn{2}{|c|}{ Asset Illiquidity } & \multicolumn{2}{|c|}{ \%Uninsured } \\
\hline Specification & Sensitivity & Level & Sensitivity & Level & & Sensitivity & Level & Sensitivity & Level \\
\hline & (1) & $(2)$ & (3) & $(4)$ & & (5) & $(6)$ & (7) & $(8)$ \\
\hline$R O A_{i t-1} \times$ & & & & & $R O A_{i t-1} \times$ & & & & \\
\hline MisMatch $_{i t-1}$ & $10.374 * * *$ & & $0.036^{*}$ & & $I_{\text {MisMatch }}$ & $3.633^{* * *}$ & & $2.948 * * *$ & \\
\hline & $(3.391)$ & & $(1.802)$ & & & $(4.157)$ & & $(3.214)$ & \\
\hline$R O A_{i t-1}$ & $4.244^{* * *}$ & & $3.916^{* * *}$ & & $R O A_{i t-1}$ & $2.326^{* * *}$ & & $2.353^{* * *}$ & \\
\hline & $(4.787)$ & & $(4.835)$ & & & $(4.819)$ & & $(4.827)$ & \\
\hline MisMatch $_{i t-1}$ & & & & & $I_{\text {MisMatch }} \times$ & & & & \\
\hline$\times I_{R O A<M e d}$ & & $-16.073 * * *$ & & -0.035 & $I_{R O A<M e d}$ & & $-4.067 * * *$ & & $-3.860 * * *$ \\
\hline & & $(-3.779)$ & & $(-1.565)$ & & & $(-3.523)$ & & $(-3.436)$ \\
\hline$I_{R O A<M e d}$ & & $-4.322 * * *$ & & $-2.904 * * *$ & $I_{R O A<M e d}$ & & -1.111 & & -0.827 \\
\hline & & $(-4.695)$ & & $(-3.214)$ & & & $(-1.037)$ & & $\begin{array}{c}(-0.680) \\
-\end{array}$ \\
\hline MisMatch $_{i t-1}$ & $-22.738^{*}$ & -3.309 & $-1.041 * * *$ & $-0.991 * * *$ & $I_{\text {MisMatch }}$ & $-5.516 * *$ & 0.438 & $-22.485^{* * *}$ & $17.865^{* * *}$ \\
\hline & $(-1.682)$ & $(-0.364)$ & $(-5.312)$ & $(-5.212)$ & & $(-2.004)$ & $(0.281)$ & $(-4.880)$ & $(-4.804)$ \\
\hline Controls & $\mathrm{Y}$ & $\mathrm{Y}$ & $\mathrm{Y}$ & $\mathrm{Y}$ & & $\mathrm{Y}$ & $\mathrm{Y}$ & $\mathrm{Y}$ & $\mathrm{Y}$ \\
\hline Bank fixed effects & $\mathrm{Y}$ & $\mathrm{Y}$ & $\mathrm{Y}$ & $\mathrm{Y}$ & & $\mathrm{Y}$ & $\mathrm{Y}$ & $\mathrm{Y}$ & $\mathrm{Y}$ \\
\hline Observations & 286,830 & 286,830 & 284,157 & 284,157 & & 99,090 & 99,090 & 92,748 & 92,748 \\
\hline Adj. R-squared & 0.073 & 0.073 & 0.109 & 0.109 & & 0.075 & 0.074 & 0.124 & 0.123 \\
\hline
\end{tabular}




\section{Table A3: Systematic vs idiosyncratic performance shocks using single state banks only}

This table repeats the analyses in Table 8 of the main draft except we restrict the sample to be banks that operate in only one state. In addition to bank fixed effects, we also include the interactive fixed effects of state and yearquarter to flexibly absorb any state-specific responses to systematic shocks. Panel A presents the results from the sensitivity specification where ROA_Sys is the average ROA for all banks in a given quarter and ROA_Idio is the difference between $R O A$ and ROA_Sys. Panel B presents the results for level specifications where $I_{R O A<M e d}$ is the indicator variable for whether the bank has below sample median $R O A$ performance, $I_{\text {Poorsys \& ROA }<\text { Med }}=$ $I_{R O A<M e d} * I\left(R O A_{-} S y s_{t}<\right.$ Cutof $\left.f_{\text {sys }}\right)$ where Cutoff sys $_{\text {is }}$ is set to equal to the bottom 1/3, 1/4, and 1/5 of sample ROA_Sys in columns (1) and (4), in columns (2) and (5), and in columns (4) and (6), respectively. Similarly, $I_{\text {PoorIdio \& ROA }<\text { Med }}=I_{R O A<M e d} * I\left(\right.$ ROA_Idio $_{i t}<$ Cutof $\left._{\text {idio }}\right)$ where Cutoff $f_{\text {idio }}$ is set to equal to the bottom $1 / 3$, $1 / 4$, and 1/5 of sample ROA_Idio in columns (1) and (4), in columns (2) and (5), and in columns (4) and (6), respectively. Controls include bank characteristics and the interaction terms of their demeaned values with either ROA_Sys and ROA_Idio in Panel A or the performance indicator variables in Panel B, lagged deposit rates, and macro controls. T-statistics, based on two-way clustered standard errors at the bank and year-quarter level, are presented in the parenthesis below. Statistical significance (two-sided) at the $10 \%, 5 \%$, and $1 \%$ level is denoted by $*$, **, and $* * *$, respectively.

Panel A: Sensitivity specification

\begin{tabular}{|c|c|c|}
\hline MisMatch measure & Asset Illiquidity & $\%$ Uninsured \\
\hline \multirow[t]{2}{*}{ Dependent variable } & $\Delta D e p_{i t}^{U}$ & $\Delta D e p_{i t}^{U}$ \\
\hline & $(1)$ & $(2)$ \\
\hline \multirow[t]{2}{*}{ ROA_Sys $_{t-1} \times$ MisMatch $_{i t-1}$} & $7.105^{* * *}$ & $0.069 * * *$ \\
\hline & $(3.853)$ & $(4.382)$ \\
\hline \multirow[t]{2}{*}{ ROA_Idio $_{i t-1} \times$ MisMatch $_{i t-1}$} & 0.374 & $0.017 * * *$ \\
\hline & $(1.117)$ & $(4.236)$ \\
\hline \multirow[t]{2}{*}{ ROA_Idio $i t-1$} & $0.660 * * *$ & $0.667 * * *$ \\
\hline & $(10.294)$ & $(9.823)$ \\
\hline \multirow[t]{2}{*}{ MisMatch $_{i t-1}$} & -2.954 & $-0.289 * * *$ \\
\hline & $(-1.532)$ & $(-14.705)$ \\
\hline Controls & Y & $\mathrm{Y}$ \\
\hline Bank fixed effects & $\mathrm{Y}$ & $\mathrm{Y}$ \\
\hline State ${ }^{*} Q$ tr fixed effects & $\mathrm{Y}$ & $\mathrm{Y}$ \\
\hline Observations & 260,279 & 257,619 \\
\hline Adj. R-squared & 0.315 & 0.326 \\
\hline
\end{tabular}


Panel B: Level specification

\begin{tabular}{|c|c|c|c|c|c|c|}
\hline \multirow{2}{*}{$\begin{array}{l}\text { MisMatch measure } \\
\text { Poor shock cut-off }\end{array}$} & \multicolumn{3}{|c|}{ Asset Illiquidity } & \multicolumn{3}{|c|}{$\%$ Uninsured } \\
\hline & $\begin{array}{c}\text { Bottom } \\
1 / 3^{\text {rd }} \\
\end{array}$ & $\begin{array}{c}\text { Bottom } \\
1 / 4^{\text {th }}\end{array}$ & $\begin{array}{c}\text { Bottom } \\
1 / 5^{\text {th }} \\
\end{array}$ & $\begin{array}{c}\text { Bottom } \\
1 / 3^{\text {rd }} \\
\end{array}$ & $\begin{array}{c}\text { Bottom } \\
1 / 4^{\text {th }} \\
\end{array}$ & $\begin{array}{c}\text { Bottom } \\
1 / 5^{\text {th }} \\
\end{array}$ \\
\hline \multirow[t]{2}{*}{ Dependent variable } & $\Delta D e p_{i t}^{U}$ & $\Delta D e p_{i t}^{U}$ & $\Delta D e p_{i t}^{U}$ & $\Delta D e p_{i t}^{U}$ & $\Delta D e p_{i t}^{U}$ & $\Delta D e p_{i t}^{U}$ \\
\hline & $(1)$ & $(2)$ & $(3)$ & $(4)$ & $(5)$ & $(6)$ \\
\hline MisMatch $_{\text {it-1 }} \times I_{\text {PoorSys } \& \text { ROA }<\text { Med }}$ & $\begin{array}{c}-4.872 * * * \\
(-4.457)\end{array}$ & $\begin{array}{c}-4.296 * * * \\
(-3.317)\end{array}$ & $\begin{array}{c}-3.938 * * * \\
(-2.638)\end{array}$ & $\begin{array}{c}-0.037 * * * \\
(-2.985)\end{array}$ & $\begin{array}{l}-0.035 * * \\
(-2.626)\end{array}$ & $\begin{array}{c}-0.039 * * * \\
(-2.652)\end{array}$ \\
\hline MisMatch $_{\text {it- } 1} \times I_{\text {Poorldio } \& \text { ROA }<\text { Med }}$ & $\begin{array}{c}-1.837 * * * \\
(-3.084)\end{array}$ & $\begin{array}{c}-1.958 * * * \\
(-2.897)\end{array}$ & $\begin{array}{c}-2.231^{* * *} \\
(-3.062)\end{array}$ & $\begin{array}{c}-0.021^{* * *} \\
(-3.383)\end{array}$ & $\begin{array}{c}-0.023^{* * *} \\
(-3.189)\end{array}$ & $\begin{array}{c}-0.025^{* * * *} \\
(-3.428)\end{array}$ \\
\hline MisMatch $_{i t-1} \times I_{R O A<M e d}$ & $\begin{array}{c}0.627 \\
(1.142)\end{array}$ & $\begin{array}{c}0.007 \\
(0.015)\end{array}$ & $\begin{array}{c}-0.262 \\
(-0.527)\end{array}$ & $\begin{array}{c}0.002 \\
(0.373)\end{array}$ & $\begin{array}{c}-0.003 \\
(-0.435)\end{array}$ & $\begin{array}{c}-0.005 \\
(-0.802)\end{array}$ \\
\hline$I_{R O A<M e d}$ & $\begin{array}{c}-0.561 * * * \\
(-3.403)\end{array}$ & $\begin{array}{c}-0.611^{* * *} \\
(-3.903)\end{array}$ & $\begin{array}{c}-0.666 * * * \\
(-4.363)\end{array}$ & $\begin{array}{c}-0.524^{* * *} \\
(-3.168)\end{array}$ & $\begin{array}{c}-0.580 * * * \\
(-3.666)\end{array}$ & $\begin{array}{c}-0.635 * * * \\
(-4.142)\end{array}$ \\
\hline$I_{\text {Poorsys } \& \text { ROA }<\text { Med }}$ & $\begin{array}{c}-0.139 \\
(-0.930)\end{array}$ & $\begin{array}{c}-0.094 \\
(-0.527)\end{array}$ & $\begin{array}{c}0.062 \\
(0.311)\end{array}$ & $\begin{array}{c}-0.114 \\
(-0.700)\end{array}$ & $\begin{array}{c}-0.035 \\
(-0.167)\end{array}$ & $\begin{array}{c}0.234 \\
(0.975)\end{array}$ \\
\hline$I_{\text {PoorIdio } \& \text { ROA }<\text { Med }}$ & $\begin{array}{c}-0.290 * * * \\
(-3.155)\end{array}$ & $\begin{array}{c}-0.286 * * * \\
(-2.970)\end{array}$ & $\begin{array}{l}-0.259 * * \\
(-2.260)\end{array}$ & $\begin{array}{c}-0.333^{* * *} \\
(-3.556)\end{array}$ & $\begin{array}{c}-0.312^{* * *} \\
(-3.189)\end{array}$ & $\begin{array}{c}-0.304 * * * \\
(-2.687)\end{array}$ \\
\hline MisMatch $_{i t-1}$ & $\begin{array}{c}4.977 * * * \\
(8.518)\end{array}$ & $\begin{array}{c}4.978 * * * \\
(8.546)\end{array}$ & $\begin{array}{c}4.970 * * * \\
(8.521)\end{array}$ & $\begin{array}{l}-0.213^{* * *} \\
(-13.075)\end{array}$ & $\begin{array}{l}-0.213^{* * *} \\
(-13.047)\end{array}$ & $\begin{array}{c}-0.213^{* * *} \\
(-13.009)\end{array}$ \\
\hline Controls & $\mathrm{Y}$ & $\mathrm{Y}$ & $\mathrm{Y}$ & $\mathrm{Y}$ & $\mathrm{Y}$ & $\mathrm{Y}$ \\
\hline Bank fixed effects & $\mathrm{Y}$ & $\mathrm{Y}$ & $\mathrm{Y}$ & $\mathrm{Y}$ & $\mathrm{Y}$ & $\mathrm{Y}$ \\
\hline State*Qtr fixed effects & $\mathrm{Y}$ & $\mathrm{Y}$ & $\mathrm{Y}$ & $\mathrm{Y}$ & $\mathrm{Y}$ & $\mathrm{Y}$ \\
\hline Observations & 260,279 & 260,279 & 260,279 & 257,619 & 257,619 & 257,619 \\
\hline Adj. R-squared & 0.314 & 0.314 & 0.314 & 0.325 & 0.325 & 0.325 \\
\hline
\end{tabular}




\section{Table A4. Robustness to using \%Uninsured measured at the end of the preceding quarter}

This table presents evidence on the robustness of our results when we measure \%Uninsured at the end of the previous (instead of the average over the previous three years). Columns (1) to (2) present both the sensitivity and levels specifications for the whole sample and columns (3) to (4) present the results for the matched samples. Controls include time-varying bank characteristics and the interactive terms of their sample demeaned value with either $R O A$ or $I_{R O A<M e d}$, lagged deposit rates, and macro controls. T-statistics, based on two-way clustered standard errors at the bank and year-quarter level, are presented in the parenthesis below. Statistical significance (two-sided) at the $10 \%, 5 \%$, and $1 \%$ level is denoted by *, **, and ${ }^{* * *}$, respectively.

\begin{tabular}{|c|c|c|c|c|c|}
\hline \multirow{2}{*}{$\begin{array}{l}\text { Sample } \\
\text { Specification }\end{array}$} & \multicolumn{2}{|c|}{ Whole sample } & & \multicolumn{2}{|c|}{ Matched sample } \\
\hline & Sensitivity & Levels & & Sensitivity & Levels \\
\hline & (1) & (2) & & (3) & (4) \\
\hline$R O A_{i t-1} \times$ & & & $R O A_{i t-1} \times$ & & \\
\hline \multirow[t]{2}{*}{ MisMatch $_{\text {it }-1}$} & $0.048 * * *$ & & $I_{\text {MisMatch }}$ & $2.205 * * *$ & \\
\hline & (3.351) & & & (3.519) & \\
\hline \multirow[t]{2}{*}{$R O A_{i t-1}$} & $1.714^{* * *}$ & & $R O A_{i t-1}$ & 0.307 & \\
\hline & $(5.742)$ & & & (1.413) & \\
\hline MisMatch $_{i t-1}$ & & & $I_{\text {MisMatch }} \times$ & & \\
\hline$\times I_{R O A<M e d}$ & & $-0.047 * *$ & $I_{R O A<M e d}$ & & $-2.304 * * *$ \\
\hline & & $(-2.327)$ & & & $(-3.017)$ \\
\hline$I_{R O A<M e d}$ & & $-1.097 * * *$ & $I_{R O A<M e d}$ & & 0.641 \\
\hline & & $(-3.500)$ & & & (1.218) \\
\hline MisMatch $_{i t-1}$ & $-0.366 * * *$ & $-0.299 * * *$ & $I_{\text {MisMatch }}$ & $-8.982 * * *$ & $-5.867 * * *$ \\
\hline & $(-4.610)$ & $(-4.853)$ & & $(-4.055)$ & $(-4.067)$ \\
\hline Controls & $\mathrm{Y}$ & $\mathrm{Y}$ & & $\mathrm{Y}$ & $\mathrm{Y}$ \\
\hline Bank fixed effects & $\mathrm{Y}$ & $\mathrm{Y}$ & & $\mathrm{Y}$ & $\mathrm{Y}$ \\
\hline Observations & 284,158 & 284,158 & & 100,211 & 100,211 \\
\hline Adj. R-squared & 0.170 & 0.168 & & 0.166 & 0.162 \\
\hline
\end{tabular}

